Det här verket har digitaliserats vid Göteborgs universitetsbibliotek.

Alla tryckta texter är OCR-tolkade till maskinläsbar text. Det betyder att du kan söka och kopiera texten från dokumentet. Vissa äldre dokument med dåligt tryck kan vara svåra att OCR-tolka korrekt vilket medför att den OCR-tolkade texten kan innehålla fel och därför bör man visuellt jämföra med verkets bilder för att avgöra vad som är riktigt.

This work has been digitised at Gothenburg University Library.

All printed texts have been OCR-processed and converted to machine readable text. This means that you can search and copy text from the document. Some early printed books are hard to OCR-process correctly and the text may contain errors, so one should always visually compare it with the images to determine what is correct. 
PUBLICATIONS OF

THE INSTITUTE OF ECONOMIC HISTORY OF GOTHENBURG UNIVERSITY

(Meddelanden från Ekonomisk-historiska institutionen vid Göteborgs universitet)

\section{GERMAN STEEL and SWEDISH IRON ORE 1939-1945}

BY

MARTIN FRITZ

GOTEBORG

1974 


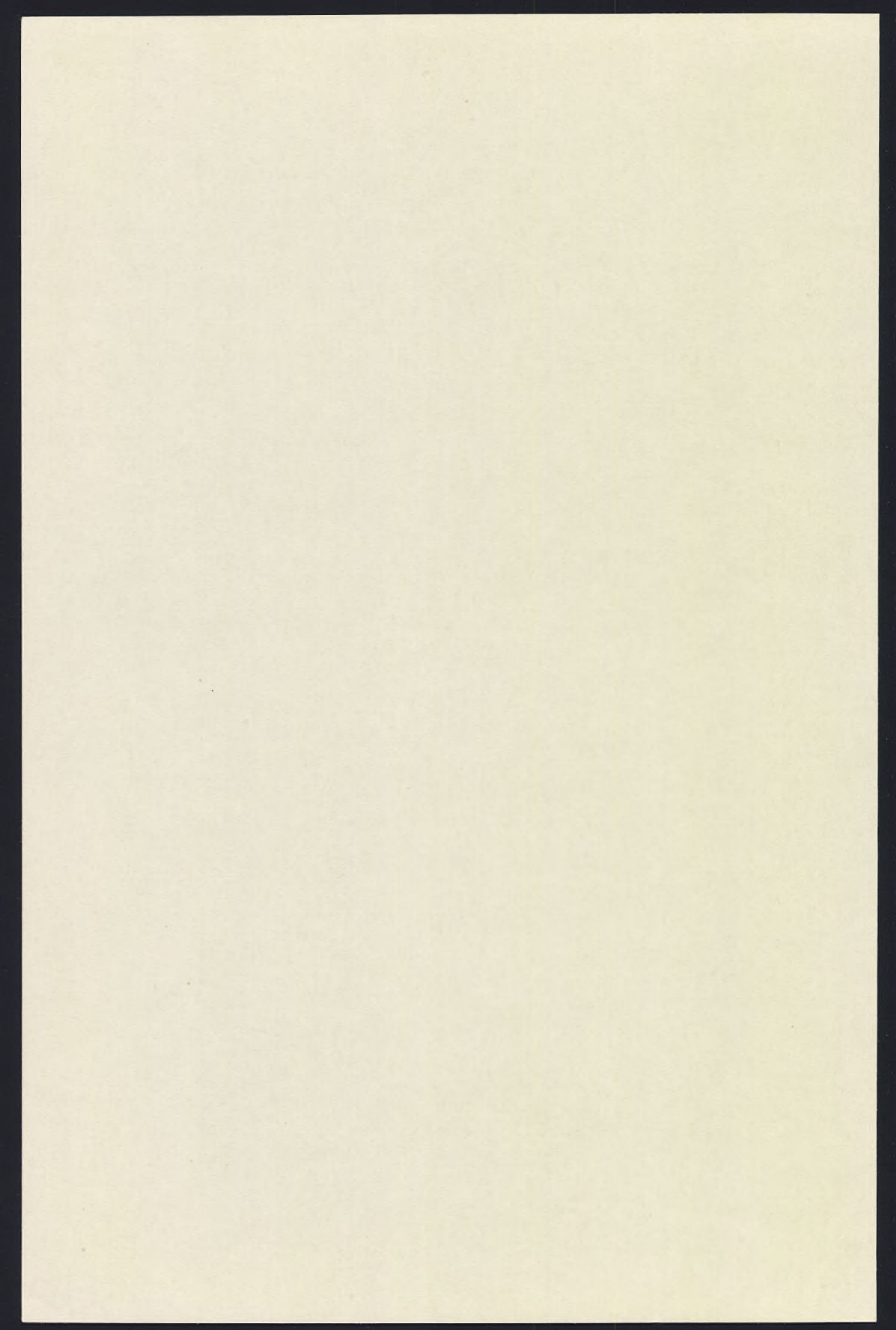


PUBLICATIONS OF

THE INSTITUTE OF ECONOMIC HISTORY OF GOTHENBURG UNIVERSITY

(Meddelanden från Ekonomisk-historiska institutionen vid Göteborgs universitet)

\section{GERMAN STEEL and SWEDISH IRON ORE}

1939-1945

BY

MARTIN FRITZ

GÖTEBORG

1974 
UNDER PRESSURE FROM ABROAD

Sectors of the Swedish economy 1939-1945

ISBN 91-85196-03-7

Translated by Eva and Allan Green

Published with a grant from the Swedish Council for Social Science Research

KUNGSBACKA 1974

ELANDERS BOKTRYCKERI AKTIEBOLAG 


\section{CONTENTS}

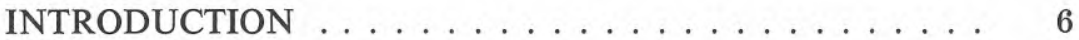

I. THE GERMAN STEEL INDUSTRY . . . . . . . . . . 8

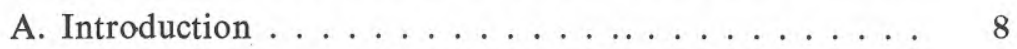

B. The quantitative development of the production of pig-

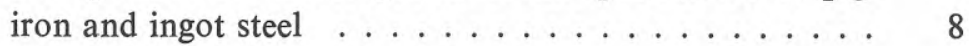

1. The production in 'Altreich' . . . . . . . . . 8

2. The production of pig-iron and ingot steel in the part of Europe ruled by Germany . . . . . . . . . . . 12

C. General conditions in the German steel industry . . . . . 17

1. Introduction . . . . . . . . . . . . . 17

2. The question of capacity . . . . . . . . . 21

3. The production of ingot steel . . . . . . . . . 23

4. The production of pig-iron . . . . . . . . . . 26

II. FOREIGN POLICY AND THE SUPPLY OF IRON ORE 29

A. Introduction . . . . . . . . . . . . . . . . . . . 29

B. The period up to the outbreak of war . . . . . 30

1. The supply of domestic iron ore . . . . . . . . 30

2. The imports of iron ore . . . . . . . . . . . 33

3. Summary . . . . . . . . . . . . . . . 39

C. The first year of the war (September 1939-June 1940) . . 41

1. The supply of domestic iron ore . . . . . . . . . 41

2. The imports of iron ore . . . . . . . . . . 42

3. Summary . . . . . . . . . . . . . . 47 
D. The German iron ore supply during the war years $\ldots .48$

1. The domestic production of iron ore . . . . . . . 48

2. The imports of iron ore . . . . . . . . . 51

3. Summary . . . . . . . . . . . . 52

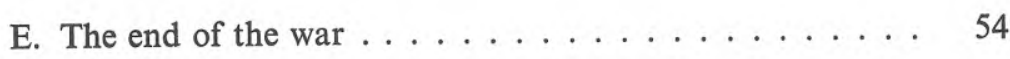

F. Summary $\ldots \ldots \ldots \ldots \ldots \ldots \ldots \ldots \ldots$

III. THE TRANSPORTING OF IRON ORE BETWEEN SWEDEN AND GERMANY . . . . . . . . . . . 59

A. Introduction . . . . . . . . . . . . . . . 59

B. Shipping conditions during the latter half of the 1930 s . 61

C. From the outbreak of the war to the start of the blockade

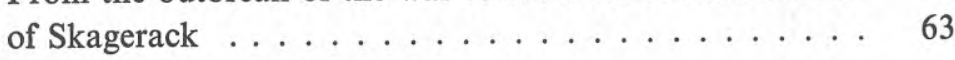

D. From the start of the blockade of Skagerack onwards: the

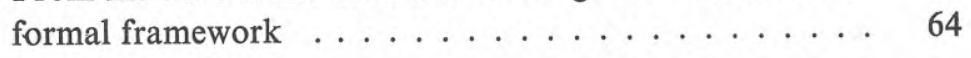

E. From the start of the blockade of Skagerack onwards: carriage of goods by sea as a bottleneck for the German iron ore supply . . . . . . . . . . . 66

1. The Swedish shipping ports . . . . . . . . . 66

2. The import ports on the Continent $\ldots \ldots \ldots \ldots 68$

3. The composition of the shipping . . . . . . . 70

4. The shortage of shipping-a bottleneck for the iron ore supply? . . . . . . . . . . . . 71

IV. THE IRON ORE SUPPLY FROM A SOCIO-ECONOMIC AND COMMERCIAL POINT OF VIEW . . . . . . . 77

A. Introduction . . . . . . . . . . . . . . . . 77

B. Questions of fuel, labour and capacity in German pig-iron production. . . . . . . . . . . . 80

C. The price relationship between domestic and Swedish

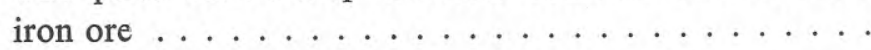


V. IRON ORE QUALITY AND THE IRON ORE SUPPLY 91 A. Introduction . . . . . . . . . . . . . . . 91

B. Germany's supply of raw materials for the production of high quality steel . . . . . . . . . . . . . . . 92

1. Introduction . . . . . . . . . . . . . . . . . 92

2. The adaptability of Thomas steel . . . . . . . . . . 94

3. The supply of scrap iron . . . . . . . . . . . 95

4. The supply of grades of iron ore with a low phosphorus

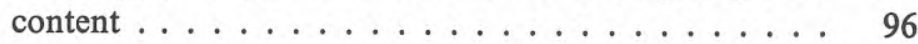

C. Summary . . . . . . . . . . . . . . . . . 102

VI. SWEDEN'S IRON ORE EXPORTS AND WAR TRADE POLICY . . . . . . . . . . . . . . . . 105

A. Introduction . . . . . . . . . . . . . . . . 105

B. The period up to the outbreak of war . . . . . . 108

C. From the outbreak of war to 9 April $1940 \ldots \ldots$. . . . 110

D. From 9 April to the summer of $1943 \ldots \ldots \ldots \ldots$

E. From the summer of 1943 onwards . . . . . . . . . . 119

F. Concluding observations . . . . . . . . . . 126

SUMMARY . . . . . . . . . . . . . . . . . . . . 127

ABBREVIATIONS . . . . . . . . . . . . . . . 130

REFERENCES . . . . . . . . . . . . . . . 131

LIST OF TABLES $\ldots \ldots \ldots \ldots \ldots \ldots \ldots \ldots \ldots$

MAP . . . . . . . . . . . . . . . . . 137 


\section{INTRODUCTION}

During the period between the world wars Sweden's trade with Germany constituted about one-fifth of Sweden's total foreign trade. During the second world war Germany became completely dominant as a trading partner. During the war years the extent and composition of Swedish-German trade received formal expression in yearly trade agreements.

The most valuable single item exported to Germany during the second world war was iron ore. Its comparative importance also increased during this period, constituting about $8 \%$ of Sweden's total exports by the middle of the 1930 s and about $14 \%$ during the war years. ${ }^{1}$ )

The Swedish export of iron ore during the second world war is among the most widely discussed problems of modern Swedish economic and political history. The importance of Swedish iron ore for the German war potential has been the central topic of discussion, in which different scholars have held diametrically opposite points of view. Some have maintained that the Swedish iron ore was a conditio sine qua non for the German armament industry, while others have contended that although the Swedish iron ore played an important role quantitatively, if deliveries from Sweden had been suspended they could have been replaced by other iron ore-home produced or imported-by existing stocks, or by increased supplies of scrap-iron. In the light of the assessment of the importance of Swedish iron ore for Germany political events, i.e. the relations between Sweden and the Great Powers at war, have also been interpreted. ${ }^{2}$ )

$\left.{ }^{1}\right)$ SOS, Handel. The relative importance of Swedish iron ore among Swedish exports has never been greater than during the second world war.

${ }^{2}$ ) There is hardly any point in giving an account here of all the works in which the Swedish iron ore exports have been dealt with-often in sterotyped interpretations. For discussion about the importance, measured in terms of percentage, of the Swedish exports of iron ore, see Fritz (1973), p. $133 \mathrm{ff}$. The impression that the iron ore was of very great importance, which is apparent e.g. in Medlicott, I, pp. $180 \mathrm{ff}$. 
In wartime differing views were already held on this important question, ${ }^{3}$ ) and the various opinions of the scholars depend at least to a certain extent on the sources on which the scholar in question has based his research. The contradictions among the scholars seem to be due mainly to an incomplete knowledge of certain technical and economic realities for the German steel industry which existed during this period.

A review of the conditions of the German steel industry (Chapter I) will therefore provide a fruitful starting-point for fresh research. As the production of steel in Germany at the end of the 1930s and during the war years was completely inadequate to cater for the country's expanding need, it is first of all of interest to examine the reasons for the shortage which arose. After these general considerations the research which follows will be devoted to the German supply of iron ore in the context of the question whether the supply of iron ore was a bottle-neck for German steel production. To answer this question the supply must be examined in terms of changing political availability (II), transport possibilities (III), the economics of iron ore supply (IV) and the technology of the steel industry (V). Swedish iron ore will also be put in the forefront of this report. However, more consciously than before Swedish iron ore is being placed in a wider context-this applies also to the concluding chapter (VI) on Swedish trade policy-and not until then will it be possible to draw cogent conclusions.

\footnotetext{
and Woodward, pp. $42 \mathrm{ff}$. derives from the exaggerated English view. The scholars who have worked with German sources hold an almost diametrically opposite view: see the discussion in Fritz (1973), p. $133 \mathrm{ff}$. Even in later works these scholars have persisted in their view, Jäger (1969), pp. $176 \mathrm{ff}$. (note however p. 136, where the opposite view is expressed) and Milward (1970), p. 212. Bröyn also subscribes to the latter view, pp. $110 \mathrm{f}$.

${ }^{3}$ ) Even within the trade policy department of the Swedish Foreign Office there was a feeling of uncertainty about the real importance of Swedish iron ore. Contemporary analyses-by own and outside experts alike-remained on a very general level, and the conclusions are tentative and full of reservations. Preliminär promemoria 28/3-39 (Hägglöf), PM beträffande Tysklands järnförsörjning 30/3-40 (Tigerschiöld, Jernkontoret), H40Ct (UD A).
} 


\section{THE GERMAN STEEL INDUSTRY}

\section{A. Introduction}

In order to be able to discuss with fair success the role of Swedish iron ore in a German war economy it is vital first to stop and consider the development of the steel industry in Germany during the period between the wars and during the years of the second world war. The exposition which follows is in two stages, a statistical account of the quantitative development of the production of pig-iron and ingot steel, ${ }^{1}$ ) and also a discussion about general conditions in this field. Towards the end of this discussion the supply of iron ore will also be mentioned, and there the questions to be dealt with in the research which follows will be introduced.

\section{B. The quantitative development of the production of pig-iron and ingot steel}

\section{The Production in 'Altreich'}

The widespread trade slump during the first years of the 1930s obviously also strongly affected the German steel industry, and brought about a large decline in production. The German production of pig-iron in 1932 did not amount to a third of the production of 1929. During the following years a significant recovery took place. The production of

$\left.{ }^{1}\right)$ Certain advantages accrue from the use of the production of pig-iron and ingot steel as a gauge of the general development of the steel sector. Information about the production of ingot steel is to be preferred to information about the rolling mill production, since the former includes steel casting, which was of great importance for the manufacture of ammunition. Eisenwirtschaft seit Kriegsausbruch p. 5, R10III/6 (B A). The best statistical account of the German steel industry is a confidential publication, Übersichten über die Eisen schaffende Industrie Deutschlands 1937, FD 264/46 (IWM). 
1929 was only exceeded for the first time in 1936, and 1938 became the best year in terms of production. During the war years a certain decline occurred, which cannot however be considered in any sense catastrophic. In 1944 larger quantities of pig-iron were still produced than in 1935.

Table 1. The production of pig-iron in Germany 1928-1944 (1000 tons)

\begin{tabular}{|c|c|c|c|c|c|}
\hline Year & Production & Year & Production & Year & Production \\
\hline 1928 & 11760 & 1934 & 8717 & 1940 & 13955 \\
\hline 1929 & 13239 & 1935 & 12846 & 1941 & 15441 \\
\hline 1930 & 9698 & 1936 & 15302 & 1942 & 15332 \\
\hline 1931 & 6061 & 1937 & 15960 & 1943 & 15972 \\
\hline 1932 & 3932 & 1938 & 18045 & 1944 & 13369 \\
\hline 1933 & 5247 & 1939 & 17478 & & \\
\hline
\end{tabular}

Source: Statistisches Handbuch von Deutschland 1928-1944, p. 288.

The production of pig-iron was to a large extent concentrated in the Ruhr area. During the latter years of the 1930s this district was responsible for about $70 \%$ of the total German production. From 1942 onwards its share was reduced to well over $60 \%{ }^{2}$ )

Pig-iron was produced by melting down iron ore in furnaces using coke as fuel. The pig-iron was divided into various categories according to the chemical composition of the iron ore, mainly its phosphorus content. High phosphorus pig-iron was called Thomas pig-iron. This pig-iron as well as the specially low phosphorus Bessemer pig-iron

$\left.{ }^{2}\right)$ Statistisches Handbuch von Deutschland 1928-1944 p. 288. For a more detailed regional breakdown, see these statistics. Furthermore the production was concentrated in large units. The largest steel concern in Germany, Vereinigte Stahlwerke, possessed a blast furnace capacity of over 8 million tons of pig-iron in 1937. The concern shows the following development of production (in thousands of tons):

\begin{tabular}{lcccrrrr}
\hline Year & Pig-iron & Ingot steel & & Year & Pig-iron & Ingot steel \\
\cline { 1 - 2 } \cline { 6 - 7 } $1938 / 39$ & 7594 & 8953 & & $1942 / 43$ & 6531 & 7658 \\
$1939 / 40$ & 5917 & 7534 & & $1943 / 44$ & 5961 & 7209 \\
$1940 / 41$ & 5907 & 7452 & & $1944 / 45$ & 752 & 901 \\
$1941 / 42$ & 5307 & 7080 & & & & \\
\hline
\end{tabular}

Source: FD1455/45 (IWM) 
was then transported in liquid form into a convert where it was blown into steel. Thomas pig-iron was the dominant variety in the German production of pig-iron. In the pre-war period as well as during the actual war years the pig-iron produced from phosphorus iron ore constituted about two-thirds of the total German production of pig-iron. ${ }^{3}$ )

Part of the pig-iron was sent, together with scrap iron (the steelworks' own circulating scrap as well as other scrap, see below, p. 23) to steel furnaces driven by producer-gas in order to make ingot steel, called Martin steel. For the acid Martin process much low phosphorus iron ore was needed as a base, and for the basic variation, which was totally predominant, iron ore with a fairly low phosphorus content $(0.1 \%$ at the most) was required.

The German foreign trade in pig-iron was insignificant during this period, and therefore it did not succeed in influencing the volume of ingot steel production. Therefore this shows a development similar to the production of pig-iron:

Table 2. The production of ingot steel in Germany 1928-1944 (1000 tons)

\begin{tabular}{cccccccc}
\hline Year & Production & & Year & Production & & Year & Production \\
\cline { 1 - 1 } \cline { 6 - 7 } 1928 & 14368 & & 1934 & 11916 & & 1940 & 19141 \\
1929 & 16246 & & 1935 & 16446 & & 1941 & 20836 \\
1930 & 11538 & & 1936 & 19216 & & 1942 & 20480 \\
1931 & 8292 & & 1937 & 19849 & & 1943 & 20758 \\
1932 & 5764 & & 1938 & 22656 & & 1944 & 18318 \\
1933 & 7612 & & 1939 & 22508 & & \\
\hline
\end{tabular}

Source: Statistisches Handbuch von Deutschland 1928-1944, p. 288.

Ingot steel was also divided into different categories according to its chemical composition. The Bessemer steel and the acid Martin steel with their low content of phosphorus were the best in terms of quality, and were used as basic materials for the manufacture of tools, ballbearings et cetera. Electric steel was often alloyed steel of high quality. The basic Martin steel did not have the distinguished quality of acid steel but it was used for superior purposes, inter alia in the armament industry. Thomas steel was used for general purposes, e.g. as building iron, for railway tracks, et cetera.

$\left.{ }^{3}\right)$ Statistisches Handbuch von Deutschland 1928-1944, p. 288. 
Table 3. The quality of the German production of ingot steel in 1936-1944 $(\%)$

\begin{tabular}{ccccc}
\hline Year & Thomas & Bessemer & Martin & Electric \\
\hline 1936 & 42.3 & - & 55.5 & 2.1 \\
1937 & 41.5 & - & 55.7 & 2.8 \\
1938 & 41.1 & 0.8 & 54.1 & 3.9 \\
1939 & 40.8 & 1.0 & 53.1 & 5.0 \\
1940 & 35.7 & 1.9 & 55.6 & 6.7 \\
1941 & 37.9 & 1.8 & 52.9 & 7.2 \\
1942 & 38.4 & 2.2 & 51.4 & 7.9 \\
1943 & 39.3 & 2.9 & 48.2 & 9.5 \\
1944 & 37.0 & 3.5 & 48.4 & 11.0 \\
\hline
\end{tabular}

Source: Statistisches Handbuch von Deutschland 1928-1944, p. 289, Statistisches Jahrbuch für das Deutsche Reich 1941/42, p. 197.

German steel production was characterised by fairly large production of Thomas steel and occupied an exclusive position in world production. Of the total world production towards the end of the 1930s Martin steel constituted $77 \%$ (of which only $2 \%$ was of the acid variety), Thomas steel constituted $16 \%$, Bessemer steel $4 \%$ and electric steel $3 \%{ }^{4}$ )

In Germany the dominant ingot steel quality was also Martin steel, which however lost some of its importance during the war years. The same applies to Thomas steel, while electric steel (for production of high quality steel) was advancing rapidly during the war years. Martin steel was produced almost entirely by the basic process, $97.5 \%$ of it in 1939.5 )

The regional allocation of the production of ingot steel in Germany also showed a pattern similar in character to that of pig-iron. The Ruhr area, which was responsible for well over $70 \%$ of the country's total production, had its share cut to well over $60 \%$ during the war years. ${ }^{6}$ )

$\left.{ }^{4}\right)$ Sahlin-Öhman, p. 16.

$\left.{ }^{5}\right)$ Übersichten über die Eisen schaffende Industrie, p. 31, FD 264/46 (IWM). See also Statistisches Jahrbuch für das deutsche Reich 1941/42, p. 197.

$\left.{ }^{6}\right)$ Statistisches Handbuch von Deutschland 1928-1944, p. 291. For more detailed information, see these statistics. The manufacture of cast iron products is not dealt with in the present research. During the war years the production was somewhat under 4 million tons per year, ibid., p. 290. 
2. The production of pig-iron and ingot steel in the part of Europe ruled by Germany

The information on the development of production dealt with so far has related to 'Altreich', i.e. Germany as she was before 1938. During the years just before and during the world war itself Germany's territory and influence over a large part of Europe were extended. This situation leads to difficulties when attempting to estimate the 'total' German production. These problems become more acute in that the statistical material does not make it clear as to what and as to which regions the statistics are meant to refer. ${ }^{7}$ )

Some form of regional division must be made. The following division can be used: ${ }^{8}$ )

1. 'Altreich'= Germany within the borders which it had before 1938.

2. 'Reich'=Altreich + Austria, Bohemia, parts of Poland (above all eastern Upper Silesia), the areas which were lost in the Peace of Versailles, i.e. Luxemburg and Alsace-Lorraine.

3. 'Einflussgebiete' $=$ all the areas conquered by Germany except those included in 'Reich'. ${ }^{9}$ )

The definitions of 'Altreich' and 'Reich' should not give rise to any difficulties. It is much more difficult to define 'Einflussgebiete' which may be considered as equivalent to Germany's total potential. No unitary view of conquered Europe is to be found in Germany's internal statistics. Instead there were varying groupings. In 1943 Reichsvereinigung Eisen divided the steel industry into eleven different districts, of which the first six were included in 'Reich' while the rest belonged to 'Einflussgebiete'. ${ }^{10}$ )

$\left.{ }^{7}\right)$ These conditions have led to misunderstandings, e.g. by Karlbom (1965), pp. $68 \mathrm{ff} ., 89 \mathrm{ff}$.

${ }^{8}$ ) Here the author follows a grouping which has been used previously by Jäger (1969), pp. $24 \mathrm{ff}$.

9) This resulted in the division of the Minett area into two parts, one being administrative and therefore also assigned to the 'Reich' in statistics, while the other, the Meurthe-et-Moselle departement, was treated as a French area, i.e. 'Einflussgebiete'.

$\left.{ }^{10}\right)$ Hauptabteilung Statistik der Reichsvereinigung Eisen, T84:44:1322832 (N A). 


$\begin{array}{ll}\text { District number } 1 . \text { Northwest Germany } & \text { 7. Poland } \\ \text { 2. Southwest Germany } & \text { 8. Meurthe-et-Moselle } \\ \text { 3. Central Germany } & \text { 9. Belgium } \\ \text { 4. Silesia } & \text { 10. Northern France } \\ \text { 5. Bohemia-Moravia } & \text { 11. The Netherlands } \\ \text { 6. Austria } & \end{array}$

It is possible to see here that only certain central areas are considered as 'Einflussgebiete' while the steel production in other areas is not included.

In other statistics from Wirtschaftsgruppe Eisen schaffende Industrie relating to the supply of iron ore a distinction was drawn between native and foreign ores. For example, as 'foreign' iron ore French, Norwegian and Swedish iron ore were placed in the same category. ${ }^{11}$ ) Thus the statistics are not consistent with the existence of a single definition of 'Einflussgebiete'.

It is also a moot point as to which of the three alternatives in question, 'Altreich', 'Reich' or 'Einflussgebiete' is the most appropriate one to use when discussing the German steel industry. The use of 'Altreich' simplifies matters in making comparisons with pre-war times (as shown in tables 1 and 2 above) but it is not adequate to indicate the total production from which Germany benefited. 'Reich'+the whole of 'Einflussgebiete' hardly fulfils these requirements since much of the production in remote countries may only be taken as having strengthened the German war economy in a very indirect way. It would probably be most reasonable, though not beyond criticism, to work with the concept 'Reich'. The best thing would obviously be to employ all three alternatives in parallel, and then state precisely what is included within 'Einflussgebiete'.

It will now be appropriate to follow this introductory discussion with an account of the production of pig-iron in Greater Germany.

\footnotetext{
${ }^{11}$ ) Zugang bei den Hochofenwerken, Stahlwerken und den mit ihnen örtlich verbundenen Giessereien und sonstigen Verbrauchsstellen. Wirtschaftsgruppe Eisen schaffende Industrie, R13I/532 (B A).
} 
Table 4. The production of pig-iron in Greater Germany 1939-1944 (in millions of tons)

\begin{tabular}{cccccc}
\hline Year & 'Altreich' & Rest of 'Reich' Total 'Reich' & $\begin{array}{l}\text { 'Einfluss- } \\
\text { gebiete' }\end{array}$ & Total \\
\hline & & & & & \\
1939 & 17.5 & 1.0 & 18.5 & - & 18.5 \\
1940 & 14.0 & 1.5 & 15.5 & - & 15.5 \\
1941 & 15.4 & 6.0 & 21.4 & 3.0 & 24.4 \\
1942 & 15.3 & 6.9 & 22.2 & 2.7 & 24.9 \\
1943 & 16.0 & 8.2 & 24.2 & 3.6 & 27.8 \\
1944 & 13.4 & 5.7 & 19.1. & 1.8 & 20.9 \\
\hline
\end{tabular}

Source: 'Altreich', see table 1 above. 'Reich' and 'Einflussgebiete', 1939-1943, Wirtschaftsgruppe Eisen schaffende Industrie, Weltgewinnung an Roheisen und Rohstahl 1939-1943, R10III/8 (B A), 1944, Statistische Handakte, Präsident Kehrl, R3/1657 B (B A).

Note 1. From 1941 onwards Bohemia-Moravia, Luxemburg and Lorraine are included in 'Reich', and the rest of France, Belgium and Poland are included in 'Einflussgebiete'.

2. A collation from Wirtschaftsgruppe Eisen schaffende Industrie, R13I/524 (B A), shows somewhat lower figures for 'Reich'. The discrepancy is plainly due to the fact that the later collation did not include BohemiaMoravia.

A corresponding apportionment of the total 'German' production of ingot steel can also be made:

Table 5. The production of ingot steel in Greater Germany 1939-1944 (in millions of tons)

\begin{tabular}{llllll}
\hline Year & 'Altreich' & Rest of 'Reich' Total 'Reich' & $\begin{array}{l}\text { 'Einfluss- } \\
\text { gebiete' }\end{array}$ & Total \\
\hline & & & & & \\
1939 & 22.5 & 1.2 & 23.7 & - & 23.7 \\
1940 & 19.1 & 2.4 & 21.5 & - & 21.5 \\
1941 & 20.8 & 7.4 & 28.2 & 3.9 & 32.1 \\
1942 & 20.5 & 8.2 & 28.7 & 3.2 & 31.9 \\
1943 & 20.8 & 9.8 & 30.6 & 3.9 & 34.5 \\
1944 & 18.3 & 7.5 & 25.8 & 2.6 & 28.4 \\
\hline
\end{tabular}

Source: See table 4.

Note 1 . See table 4.

2. See table 4. 
Thus the military conquests, above all those in the west, not only brought about an increase in the supplies of iron ore but also an important capacity for the production of steel. Therefore the military expansion constituted an essential contribution to the total production of iron and steel. A comparison between the production in Germany during the last of the pre-war years on the one hand and during the actual war years on the other hand gave the following result.

Table 6. German production of ingot steel 1939-1944

('Altreich' 1936/38=100)

\begin{tabular}{rrrc}
\hline Year & 'Altreich' & 'Reich' & 'Reich'+'Einflussgebiete' \\
\hline & & & \\
1939 & 109 & 115 & 115 \\
1940 & 93 & 105 & 105 \\
1941 & 101 & 137 & 156 \\
1942 & 100 & 140 & 155 \\
1943 & 101 & 149 & 168 \\
1944 & 89 & 125 & 138 \\
\hline
\end{tabular}

Source: Table 5 above.

Thus the production in 'Altreich' itself was kept up to the same level as the average of the last three years of peace. If the comparison is extended to 'Reich' a sharp rise is apparent in 1941 and a peak in production in 1943. In 1944 production in the area dominated by Germany was still high above 'Altreich's' pre-war production. ${ }^{12}$ )

${ }^{12}$ ) The total monthly production of ingot steel in 1944 is shown in the following table (million tons).

\begin{tabular}{lcllc}
\hline Month & Ingot steel production & & Month & Ingot steel production \\
\cline { 1 - 1 } Jan & 3.0 & & July & 2.8 \\
Feb & 3.0 & & Aug & 2.2 \\
March & 3.2 & & Sept & 2.0 \\
April & 2.9 & & Oct & 1.7 \\
May & 2.8 & & Nov & 1.3 \\
June & 2.7 & & Dec & 1.0 \\
\hline
\end{tabular}

Source: Statistische Handakte, Präsident Kehrl, R3/1657B (B A). 
Production conditions are also illuminated by the following table:

Table 7. Production of pig-iron and ingot steel in Greater Germany 1939-1944 $(\%)$

\begin{tabular}{|c|c|c|c|c|c|c|}
\hline \multirow[t]{2}{*}{ Year } & \multicolumn{3}{|c|}{ Pig-iron } & \multicolumn{3}{|c|}{ Ingot steel } \\
\hline & 'Altreich' & Rest of 'Reich' & $\begin{array}{l}\text { 'Einfluss- } \\
\text { gebiete' }\end{array}$ & 'Altreich' & Rest of 'Reich' & $\begin{array}{l}\text { 'Einfluss- } \\
\text { gebiete' }\end{array}$ \\
\hline 1939 & 95 & 5 & - & 95 & 5 & - \\
\hline 1940 & 90 & 10 & - & 89 & 11 & - \\
\hline 1941 & 63 & 25 & 12 & 65 & 23 & 12 \\
\hline 1942 & 61 & 28 & 11 & 64 & 26 & 10 \\
\hline 1943 & 58 & 29 & 13 & 60 & 29 & 11 \\
\hline 1944 & 64 & 27 & 9 & 65 & 26 & 9 \\
\hline
\end{tabular}

Source: Table 4 and 5 above.

The production of ingot steel within 'Altreich' was comparatively higher than the production of pig-iron. This meant among other things that pig-iron was transported from blast furnaces in the rest of the 'Reich' to steelworks in 'Altreich'.

The division of the various qualities of ingot steel as between 'Altreich', 'Reich' and 'Einflussgebiete' does not form a clear pattern. Certain information from the year 1943 may illustrate this situation:

Table 8. The qualities of ingot steel produced in Greater Germany in 1943 $(\%)$

\begin{tabular}{lccc}
\hline & 'Altreich' & Rest of 'Reich' & 'Einflussgebiete' \\
\hline Thomas & 39.3 & 44.7 & 59.5 \\
Martin & 48.2 & 46.6 & 33.9 \\
Electric & 9.5 & 8.3 & 4.2 \\
Other & 3.0 & 0.4 & 2.4 \\
\hline
\end{tabular}

Source: Statistisches Handbuch von Deutschland 1928-1944, p. 289, Statistische Handakte, Präsident Kehrl, R3/1657B (B A).

Comparatively large quantities of ordinary Thomas steel were produced in the rest of the 'Reich' and in 'Einflussgebiete' as is evident from the table. In France in particular, Thomas steel was produced to a striking degree, in the Minett area almost $90 \%$ of the total steel production. ${ }^{13}$ )

13) According to Milward (1970), p. 213 , almost $80 \%$ of the French ingot steel production consisted of Thomas ingot steel. Die Hüttenwerke in Minettgebiet, in Belgien und in Nordfrankreich, Juli 1942, T71:18:408853 ff. (N A). 


\section{General conditions in the German steel industry}

\section{Introduction}

In spite of the sharply rising production of pig-iron and steel in Germany during the second half of the 1930s the acceleration in pace seems still to have been too slow. In fact the demand for steel rose even faster because of extensive investments in industry, especially in the steel industry itself, the building of motorways, and not least because of the rapidly growing need of the Defence Department for special high quality steel among other things. The inadequacy in production became apparent from 1937 and was further accentuated when war broke out. ${ }^{14}$ )

The German military forces were directly and indirectly large and growing consumers of steel. Just as the military forces were favoured, so the supply to the civil sector and for export was cut off:

Table 9. German steel consumption 1937-1940

$(\%)$

\begin{tabular}{lccc}
\hline & $\begin{array}{c}\text { Last } 6 \text { months } \\
1937\end{array}$ & $\begin{array}{c}\text { Jan.-Aug. } \\
1939\end{array}$ & $\begin{array}{c}\text { 4th quarter } \\
1940\end{array}$ \\
\hline $\begin{array}{l}\text { Armed forces (direct and } \\
\text { indirect) }\end{array}$ & 38.4 & 51.2 & 60.5 \\
$\begin{array}{l}\text { Civil industries except } \\
\text { key industries }\end{array}$ & 24.1 & 22.5 & 12.4 \\
$\begin{array}{l}\text { Key industries (mining, } \\
\text { steel industries, power) }\end{array}$ & 8.7 & 10.1 & 12.9 \\
Exports & 28.8 & 16.2 & 14.2 \\
\hline
\end{tabular}

Source: Reichsstelle Eisen und Stahl, Entwicklung des deutschen Eisenverbrauchs nach Gruppen, R10III:1 (B A).

Note 1. Thomas, p. 179, mentions that the military forces in the summer of 1939 took $30 \%$ of the total steel production. How he had arrived at this figure is not stated. On the other hand the figures in the table above tally fairly well with those in US Strategic Bombing Survey, p. 103, for the fourth quarter of 1939 . Of the supplies to the military forces $38.5 \%$ went to the army, $19.2 \%$ to the navy, $28 \%$ to the air force and $14.3 \%$ to the 'War construction program' at this point in time.

\footnotetext{
$\left.{ }^{14}\right)$ Klein, pp. $114 \mathrm{f}$, points out '... there was scarcely a meeting between Hitler and his economic advisers in which the steel situation was not discussed. Indeed, one gets the impression from the transcripts of these meetings, that, from the beginning of the war until 1943, a steel shortage dwarfed all othər economic problems'. See also pp. 41,126. Riedel, pp. $482 \mathrm{f}$.
} 
Thus during the pre-war years and during the war there was a shortage of steel in Germany. It was partly a question of a shortage of certain special steel, but mainly a basic general shortage of steel which never ceased to be a great problem for the German leaders, since not even the needs of the military forces could be satisfied..$^{15}$ )

The significant discrepancy between supply and demand led to a growing governmental influence in the form of a system of rationing - which was complicated, functioned badly and was changed several times - to coordinate the distribution and priority of the resources which were altogether barely sufficient. In 1937 the distribution of steel was put under Hermann Göring and the 4 year plan, and in 1942 a fundamental change took place through Albert Speer's reorganisation and coordination in Zentrale Planung. ${ }^{16}$ )

A question which arises immediately is: why didn't the German steel industry manage to increase its production faster than actually occurred? The question can also be put in this way: which were the bottlenecks within the German steel sector? It is not easy to give clear answers to the questions because of various factors. Many different products were made within the steel industry and nowhere was there uniformity in the relationship between supply and demand. It is also difficult to apply the bottleneck concept to one single stage, as the steel process often went continuously from blast furnaces to rolling mills. Also in the present research a longer period of time is studied, during which there were of course changes in the relationship between supply and demand. Finally the steel industry was also dependent to a high degree on the satisfactory functioning of the energy supply and transporta-

$\left.{ }^{15}\right)$ Thomas, pp. 130,132,179, Milward (1965), p. 110, Janssen, pp. 69 ff. Even during the late autumn of 1942 , when the German steel production was kept at a high level, Speer counted on a deficit of 780,000 tons per month. The average monthly production in the Reich in 1942 was 2.4 million tons of ingot steel. Zentrale Planung, 9:e Besprechung, FD, Handakten Milch, vol. 46 (IWM). Perhaps the clearest opinion about the shortage of steel is to be found in discussions of the Zentrale Planung, especially number 35, where spokesmen for various consumer groups (even the various defence forces) were confronted with each other. Zentrale Planung 35:e Besprechung 2/3-43, Handakten Milch, vol. 47 (IWM).

$\left.{ }^{16}\right)$ Thomas, p. 122, Klein, pp. 55, $126 \mathrm{ff}$. Neuordnung der Eisenbewirtschaftung, Vortrag von Präsident Kehrl 26/6-42, FD $4723 / 45$ (IWM). Deutschlands Rüstung im Zweiten Weltkrieg, Hitlers Konferenzen mit Albert Speer 1942-1945, p. 93 (about the formation of Zentrale Planung and the information it provides), p. 122, Caroll, pp. 132,169 f., Janssen, pp. $56 \mathrm{ff}$. 
tion. Thus disturbances within these two sectors could cause bottlenecks for the whole of the steel sector. ${ }^{17}$ )

The problems of the German steel industry have of course been pointed out in other literature, and there a series of bottlenecks has been alleged as the cause of the excessively slow increase in production. Therefore the bottleneck problem will be considered in the text which follows. First, however, the results obtained by some other scholars will be pointed out.

Burton $\mathrm{H}$. Klein has stated that there was really no question of an actual deficiency or of bottlenecks within the steel sector. The reason for the inadequate production is to be found instead in the malfunctioning of the organisation, especially the system of steel distribution..$^{18}$ ) Berenice A. Caroll argues in the same way and stresses that the steel production (up to 1939) was adequate to cater for all essential needs. That a deficiency still arose was due to the fact that non-essential needs were not hived off effectively, and that the widespread feeling that there was a steel shortage caused an unhealthy increase in demand and in stockpiling. Caroll has also pointed out the confused demarcation of powers among the various authorities and personal rivalry as causes of the paralysis in production..$^{19}$ )

The high increase in production in 1943 has been ascribed to Albert Speer's ability to make a clean break with the old malfunctioning administration and to create a new institutional framework. ${ }^{20}$ ) Klein has questioned this interpretation and thinks that the political leaders did not really try to establish an increase in production until 1942. The muddle which existed before the 'Speer era' was, according to Klein, an effect rather than a cause of inadequate production, and in the same way the concentration of power in Speer is seen as a consequence of the politicians' deliberate reliance on increased production. ${ }^{21}$ )

\footnotetext{
${ }^{17}$ ) About $20 \%$ of the goods carried on the German railways in 1937 were goods for the steel sector. Hauptring Eisen und Stahl, Rationalisierung in der Eisen schaffenden Industrie, p. 4, R10III/7 (B A).

${ }^{18)}$ Klein, pp. 114-135, 147-172.

$\left.{ }^{19}\right)$ Caroll, pp. $140 \mathrm{ff} .$, 168. When Speer became armaments minister in 1942, war production and then the steel industry too came within the sphere of five different authorities at ministerial level, and below that of eight different authorities, etc., Caroll, p. 232.

$\left.{ }^{20}\right)$ E.g. Milward (1965), pp. $72 \mathrm{ff}$.

21) Klein, pp. 172, 200 ff. Cf. Caroll, p. 247.
} 
Klein's thesis that the German steel industry would have been able, through very simple and limited contributions in various fields (e.g. increasing the number of coal-miners) to bring about an increase in production, seems atractive, but amounts to a crude simplification of a complex reality. In this context no detailed refutation of Klein will be made-this will be pursued below-but it will simply be established that there were real obstacles to production in the German steel industry. ${ }^{22}$ )

In the following text there will be a short summary of the general conditions in the steel industry with special regard to the existence of bottlenecks. ${ }^{23}$ ) The account starts with the production at the rolling mills and then continues in reverse order (cf. the sketch) leading to a discussion about the supply of iron ore. These will form the basis of the further investigation.

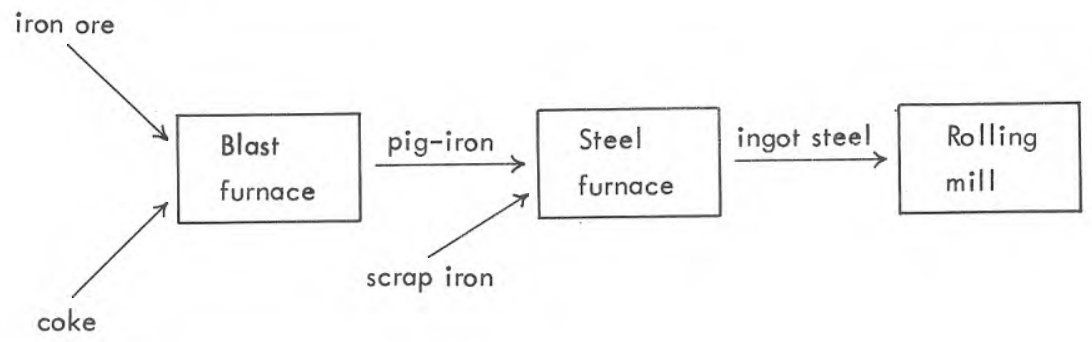

\footnotetext{
${ }^{22}$ ) As to the source of the evidence, see the account below. The literature also expresses a view which is diametrically opposed to Klein's, see e.g. The United States Strategic Bombing Survey, The Effects of Strategic Bombing on the German War Economy, p. 102, Milward (1965), p. 110, Janssen, p. 76, Petzina, p. 102 f, Riedel, p. 483, Fritz (1973), p. 137.

${ }^{23}$ ) On the other hand the hampering effect on production of the Allies' bombing attacks, which led to reduced production above all during the latter part of the war, is not mentioned. See below, p. 54 .
} 


\section{The question of capacity}

The volume of production of the rolling mills which made rolled iron goods, such as girders and other vertical section steel, rails, wire, pipes and sheet metal, was partly dependent on the supply of the basic material, viz. ingot steel, and partly on the capacity of the rolling mills. The supply of ingot steel will be dealt with under 3 (below).

However it is not worthwhile to isolate the question of the capacity of the rolling mills alone, since it was often a question of a continuous process from blast furnace via steel furnace to rolling mill all under one and the same roof. Therefore lack of capacity in one section brought about interruptions in the other sections. So it is more logical to deal with the question of capacity for the steel sector as a whole, i.e. from blast furnace to rolling mill without interruption. ${ }^{24}$ )

With the boom period of the later 1930s extensive investments had of course taken place within the steel sector in Germany. The question however was whether the investments were large enough to meet the sharply increasing needs in the various areas of German economic life. Two factors caused additional difficulties for investments in the steel industry. One was that Hitler's insistence on the greatest possible degree of self-reliance in using native, extremely low iron ores made great demands on extensive investments in concentration plants and blast furnaces. ${ }^{25}$ ) The other difficulty was deficiency of steel, mentioned above, which constituted an obstacle to a faster rate of investment within the sector itself, i.e. extending steel works or building new ones. Even the extension of the Reichswerke Hermann Göring, the pet project of the politicians, was delayed on account of the limited supply of steel. ${ }^{26}$ )

In the opinion of certain commentators (including Klein) it hardly makes sense to talk about a lack of capacity during the 1930s, as the capacity of the steel works was three to four million tons higher than the quantities actually produced. According to this view there was also a surplus capacity during the war years. After the conquests in 1940 there

${ }^{24}$ ) Hauptring Eisen und Stahl, Rationalisierung in der Eisen schaffenden Industrie, p. 5, R10III/7 (B A).

$\left.{ }^{25}\right)$ Hitler, A., Denkschrift Hitlers über die Aufgaben eines Vierjahresplans, pp. 204 ff. Eisenwirtschaft seit Kriegsausbruch, pp. 79 f., R10III/6 (B A).

${ }^{26}$ ) Zentrale Planung 35:e Besprechung 2/3-43, FD, Handakten Milch, vol. 47 (IWM). 
was a total capacity of ingot steel within the German sphere of influence of about 42 million tons, which can be compared with an actual production of 34.5 million tons during 1943 , the most successful year. ${ }^{27}$ )

However other scholars are inclined to lay emphasis on the lack of suffcient capacity as a cause for the insufficient volume of production. The civil as well as the military increase in demand had happened far too quickly and the investments within the steel sector had not kept a sufficiently rapid pace owing to the difficulties mentioned above. ${ }^{28}$ )

However Klein's comparison between capacity and actual production is not a fair one. The figure given above of a total capacity of ingot steel of 43 million tons includes among others the capacity of France (about 10 million tons), of Belgium (about 4 million tons) and of Luxemburg (about 3 million tons).

With the German conquest of France, the French blast furnaces had to be supplied with coke from the Ruhr, since deliveries from Great Britain had ceased for obvious reasons. From what follows hereafter it will be evident that there was a substantial shortage of coke in Germany. Therefore the French blast furnaces could not obtain enough coke to melt down the ore. Thus it became difficult or impossible to make use of the capacity gained by conquest to the full extent. So the actual circumstances which prevailed on the German steel market make it impossible to carry out, as Klein has done, a simple addition of Germany's old capacity to that which was newly acquired by conquest. ${ }^{29}$ )

Finally another point should also be mentioned. As has been suggested above, an increase in the use of native ore of low iron content would entail the need for a greater blast furnace capacity to produce pig-iron of a given quantity than the use of imported ores of high iron content. With the expanding production in Germany of native iron ore there was

$\left.{ }^{27}\right)$ Klein, pp. 41, 107, 115, 117. The same train of thought in Jäger (1969), pp. $301 \mathrm{f}$.

$\left.{ }^{28}\right)$ The United States Bombing Survey, p. 102, Milward (1965), p. 110, Petzina, p. 102, Janssen, p. 76, Riedel, p. 483.

$\left.{ }^{29}\right)$ Cf. The United States Bombing Survey, pp. $103 \mathrm{ff}$. The coal shortage in France was often put forward as being an obstacle to production, see e.g. Reichswirtschaftsministerium, Nachrichten von den Berg-, Hütten- und Salinenwesen in Frankreich, T71:21:412106 (N A). 
an obvious risk of an insufficiency in the capacity for melting down the iron ore in the blast furnaces, whereas the capacity in the steel furnaces and rolling mills had been adequate. In the spring of 1940 this problem became a reality. ${ }^{30}$ )

\section{The production of ingot steel}

For the production of Thomas ingot steel pig-iron was needed, and pigiron and scrap iron were required for the production of Murtin steel. In addition heat was needed for the steel furnaces, and also for the production of certain special kinds of steel and alloyed metals.

The supply of pig-iron was dependent on the production at the blast furnaces which will be dealt with next in part 4 . The import of pig-iron was utterly insignificant in relation to the native production.

As has already become apparent (p. 11), the German ingot steel comprised about half the Martin steel and a growing proportion of the electric steel. Therefore in this connection the provision of steel furnaces using scrap iron as the basic material will be of great significance. Ore and scrap iron were to an extent interchangeable, and a decrease in the supply of iron ore could in theory be compensated for by an increase in the supply of scrap iron. A diminished supply of scrap iron could also result in a bottleneck for the German steel industry.

Earlier literature has not been able to provide satisfactory information about the supply of scrap iron for the German steel industry. On the one hand it has been suggested that the supply of scrap iron in Germany increased during the war, because of intensive propaganda among other things, and that because of this the demand for ore was reduced. ${ }^{31}$ ) On the other hand it has been doubted whether scrap iron could have had such importance. ${ }^{32}$ ) However neither side has had any proof for its beliefs.

During the pre-war years the need for scrap iron in the German steel industry increased. Supplies had come to an increasing extent as imports from countries which became Germany's enemies during the war, viz. the U.S.A. and Great Britain. Because of this the German

30) Fritz (1973), p. 137.

31) E.g. Petzina, p. 107.

${ }^{32}$ ) Jäger (1969), pp. 134 f. 
scrap iron supply position should a priori have deteriorated from 1939 onwards..$^{33}$ )

Before the actual account of the supply of scrap iron is given some observations will be made. When calculating the supply of scrap iron it is important to distinguish the various types of scrap iron. The substantial part of the scrap iron which was fed into the steel furnaces was re-worked steel or circulation steel, i.e. the scrap iron which was produced during the actual manufacture of ingot steel and the products of the rolling mills. This scrap iron had the additional advantage that its properties were known. A table of the supply of scrap iron in Germany in 1943 shows the relations between the various types of scrap iron.

Table 10. The German scrap iron balance planned for 1943

(1000 tons and \%)

\begin{tabular}{lrcrc}
\hline Source of supply & 'Reich' & 'Einflussgebiete' & Total & $\%$ \\
\hline $\begin{array}{l}\text { Circulation scrap iron } \\
\text { Ordinary scrap iron, }\end{array}$ & 11640 & 1450 & 13090 & 72 \\
'Aktion'-scrap iron & 3420 & 250 & 3670 & 20 \\
$\begin{array}{l}\text { Building scrap iron from } \\
\text { Eastern Europe }\end{array}$ & 1450 & - & 1450 & 8 \\
Imports & 50 & - & 50 & - \\
Stock & 590 & - & 590 & - \\
Total & 17150 & 1700 & 18850 & 100 \\
\hline Use & & & & \\
Pig-iron production & 2500 & 240 & 2740 & 15 \\
Exports & 650 & - & 650 & 3 \\
Steel production & 14000 & 1460 & 15460 & 82 \\
Total & 17150 & 1700 & 18850 & 100 \\
\hline
\end{tabular}

Source: Reichsvereinigung Eisen, Schrott-Bilanz 1943, R10II/52 (B A).

The interesting feature in this connection is hardly the circulating scrap iron but the supplies of 'new' scrap iron. For most of the years it is possible to estimate the net addition of scrap iron.

${ }^{33}$ ) On the German supply of scrap iron, see Heavy Industries of the German Reich, Iron and Coal Trades Review, 1939, p. 473. 
Table 11. The net German supply of scrap iron 1938-1943

(millions of tons)

\begin{tabular}{ccccc}
\hline Year & Domestic scrap iron & Imports & Exports & Net addition \\
\hline 1938 & 2.5 & 1.1 & - & 3.5 \\
1939 & 3.0 & 0.7 & - & 3.7 \\
1940 & 3.2 & 0.4 & - & 3.6 \\
1941 & 3.0 & 1.1 & 0.2 & 3.9 \\
1942 & $\ldots$ & 0.9 & 0.2 &. \\
1943 & 4.9 & 0.3 & 0.4 & 4.8 \\
\hline
\end{tabular}

Source: Production 1938-1941: R10III/77 (B A), 1943: the previous table. Import/ export: Monatliche Rohstoffübersichten. T 77:198:934006. (N A).

Note 1. From 1941 onwards the imports came mainly from conquered areas in the Soviet Union.

It is evident from the table that the net addition of scrap iron to German steel works did not undergo any significant changes during the war. Consequently the shortage of scrap iron which was already substantial before the outbreak of war remained during the war. With the exception of the year 1943 when German supplies of scrap iron, thanks to Speer's action with regard to scrap iron, were judged to be satisfactory, the shortage of scrap iron constituted a bottleneck for the German steel industry. ${ }^{34}$ ) Since during the whole period, according to the information set out above, scrap iron constituted about $20 \%$ and iron ore (pig-iron) about $80 \%$ of the basic material for the production of steel, scrap iron could not make good any possible decline in the supply of iron ore.

As to the energy supply to the steel furnaces of heat gas from the coke ovens and electric heat it is obvious that changes within these fields could have a restrictive effect on production. The generation of gas in the coke ovens was dependent on the coal supply as was the current supply to the electric steel furnaces. As will become evident from what follows, the whole period was characterised by insufficient supplies of coal and coke. During the severe winter of $1939 / 40$ production stopped at several steel furnaces because of lack of gas and in the future also shortage of gas was to cause interruptions in production. ${ }^{35}$ )

\footnotetext{
${ }^{34}$ ) Hauptring Eisen und Stahl, Rationalisierung in der Eisen schaffenden Industrie, p. 8, R10III/7 (B A).

$\left.{ }^{35}\right)$ Fritz (1973), p. 138. Zentrale Planung 16:e Besprechung 23/10-42, 51:e Besprechung 17/12-43, FD, Handakten Milch, vol. 46-47 (IWM).
} 
To manufacture certain special grades of steel the steel had to be alloyed with other metals. A cut in the supply of important alloy metals could therefore hamper production. The general view in the literature, supported by Jäger's well-documented work, is however that the German steel industry was hardly short of alloy metals. The maintainance of imports, conquests of important deposits and technical innovations meant that alloy metals never gave rise to any significant bottleneck. ${ }^{36}$ )

\section{The production of pig-iron}

Pig-iron is produced by the melting of iron ore in blast furnaces. Coke was used as fuel. The volume of pig-iron production is therefore dependent on the mining of iron ore and coal and their transportation to the blast furnace. The supply of iron ore will be dealt with below.

As to the supply of coke produced from coal it is hardly convincing to maintain that Germany had a shortage of coal, being one of the world's richest countries in coal. Yet the very shortage of coal, 'Engpass Kohle', constituted one of the most important bottlenecks for the German war economy in general and the steel industry in particular (in spite of the fact that at least from 1942 onwards the steel industry had had priority in allocations), due to two other factors, namely the shortage of labour and the poorly functioning transport system. Shortage of labour was beginning to tell in Germany during the latter years of the 1930s. With the ever increasing conscription into the armed forces, the shortage, mostly of skilled labour, was accentuated. For various reasons replacements in the form of prisoners of war and foreign labour could not adequately fill the vacuum left by the miners who had been called up. ${ }^{37}$ )

The German transport system had not been equipped during the 1930's to meet the demands of the boom period for greater transport facilities. The military conquests set new distances for transport, which in turn involved increased circulation of railway engines and carriages. When the priority needs of the armed forces had to be satisfied as well, the German railways and canals did not manage to transport the required

\footnotetext{
${ }^{36}$ ) Jäger (1969), passim, especially pp. $307 \mathrm{ff}$.

${ }^{37}$ ) Eisenwirtschaft seit Kriegausbruch, p. 28, R10III/6 (B A), Klein, p. 124, note 64, Janssen, pp. 73 f., 208 ff., Deutschlands Rüstung, pp. $170 \mathrm{ff}$. In Zentrale Planung endless discussions were held about the problem of recruiting labour, e.g. meeting no. 16-18, Handakten Milch, vol. 46 (IWM).
} 
quantities of coal and coke. The shortage of engines appears to have been of special significance. Added to that was the fact that the very extensive exports of coal had to be carried by rail and this aggravated still further the shortage of coal and carriages. ${ }^{38}$ )

Without further documentation here of the situation in the coal and coke markets it is probably plain that the shortage of coke from 1939 onwards hampered the production of pig-iron in the blast furnaces. The extent of this obviously varied from region to region and at different times. However it would probably be impossible to demonstrate statistically what the shortage of coke meant for the production of German pig-iron during the war. ${ }^{39}$ )

Was the shortage of iron ore also an obstacle? Earlier literature, dealing with questions of this sort, has not been unanimous in its opinion. Some have thought that there was a constant shortage of ore ${ }^{40}$ ) others that there was a shortage of ore up to the conquest of the French mines in the summer of $1940,{ }^{41}$ ) and yet others that there is hardly a question of any kind of shortage of ore. ${ }^{42}$ ) The importance of Swedish iron ore for

${ }^{38}$ ) Eisenwirtschaft seit Kriegsausbruch, pp. 62 f., R10III/6 (B A). OKW,WiRüAmt, Verkehrsbericht 10/3-42, T77:367:1210260 (N A), Der deutsche Verkehr im Jahre 1943, FD 3042/49 (IWM), Thomas, pp. 197, 359, 363, Janssen, p. 210. Deutschlands Rüstung, p. 131. Thus for example in December 1941 no less than 44 trains a day went from the Ruhr and Upper Silesia to Italy carrying coal, i.e. approximately one every half hour. OKW,WiRüAmt, Übersicht über die Lage innerhalb des Verkehrswesens, Monat Dezember 1941, T77:367:1210455 (N A).

${ }^{39}$ ) In the Institute of Economic History at Gothenburg University Sven-Olof Olsson is preparing a paper on Swedish coal imports from Germany in which conditions on the German coal market will also be discussed. To illustrate the consequences of the coal shortage reference can be made to the fact that in the autumn of 1942 a delivery of a million tons of ore from Spain was declined by Zentrale Planung on the ground that the shortage of coke made it impossible to have it melted down. In the depressed situation the smaller consignment of steel which was to have been delivered to Spain in return was regarded as more valuable. Zentrale Planung, 16:e Besprechung 23/10-42, FD, Handakten Milch, vol. 46 (IWM). Certain information is available about production losses. During the second quarter of 1943 the decrease in the production of ingot steel was estimated at about 375,000 tons a month due to shortage of energy, 350,000 tons due to enemy action (damage +alerts), 100,000 tons due to various disturbances and 25,000 tons due to shortage of labour. Tätigkeitsbericht des Hauptringes Eisenerzeugung 28/7-44, T71:34:428467 ff. (N A).

$\left.{ }^{40}\right)$ E.g. Karlbom (1965 and 1968).

$\left.{ }^{41}\right)$ E.g. Klein, p. 117, Riedel, pp. $495 \mathrm{f}$.

${ }^{42}$ ) E.g. Milward (1967) and Jäger (1967). 
the German war economy has also been assessed in the light of the particular opinion held about the ore situation generally. The contradictory state of research makes it important to examine the question from fresh angles.

When it comes to the view of the iron ore supply as a possible bottleneck and fetter on the German steel industry, the following questions must be posed.

A) How was iron ore supplied and how was that supply affected by political situations abroad and military events?

B) The question of the iron ore supply is first of all a question of transport. Did the transport situation permit advantageous use of the political possibilities?

C) In spite of mobilisation for war and war itself the German steel industry was subject to economic laws, and of course it tried to minimise the cost of raw products. How was the supply of iron ore maintained from this point of view?

D) Iron ore is however no fixed entity. Its chemical composition shows rich variations. Among other things the phosphorus content plays a great part in the quality of the finished steel. A low phosphorus content in the ore makes it a suitable basic material for better qualities of steel, the demand for which grew particularly heavy in Germany at this time. Was the demand for a grade of ore of low phosphorus content especially difficult to satisfy? Therefore in the research which follows the German iron ore supply will be examined from the points of view of foreign politics, transport, economics and metallurgy. Only then can the question whether the iron ore supply formed a bottleneck for the German war economy be answered with precision. 


\section{II}

\section{FOREIGN POLICY AND THE SUPPLY OF IRON ORE}

\section{A. Introduction}

Having regard to the absolutely fundamental importance of the steel industry for a modern industrial state and its prospects of having a viable armaments industry it is self-evident that the supply of iron ore to the German steel industry was the subject of considerable political interest during the second half of the 1930s. ${ }^{1}$ ) This interest was accentuated by the military warfare-in theoretical discussions as well as later in harsh reality-combined with important economic warfare in which a possible cut in the deliveries of iron ore from Sweden to Germany was one of the main factors. ${ }^{2}$ )

From this it follows that Germany's need of iron ore helped to form German foreign policy as well as to influence the behaviour of her enemies. On the other hand changes in the political borders also meant changes in the supply of iron ore to the German steel industry. These two different aspects, viz. the importance of iron ore in shaping foreign policy and the influence of political changes on the supply of iron ore to the German steel industry are linked together in this chapter. Sweden's role in the present context is specially noted.

By way of introduction, however, some general points will be made. Iron ore is a far from uniform product. Variations in its iron content and the rest of its chemical composition mean that it is difficult to make comparisons between various types of iron ore. The chemical composition of the ore in fact dictates the way in which it is processed and the use to which it is ultimately put. In the present chapter consideration

$\left.{ }^{1}\right)$ On the steel consumption of the German military forces see above, p. 17.

$\left.{ }^{2}\right)$ The standard work in this field is still Medlicott, W. N., The Economic Blockade, $I-I I$. The iron ore question is mentioned in many places, mostly concentrated in part I, pp. $180 \mathrm{ff}$. 
will first be given to the ore's iron content, and a conversion into iron tons will therefore be carried out. These conversions can never claim to be completely accurate. It is therefore quite natural that corresponding conversions made by other scholars seldom or never tally with those included here. However a somewhat rough conversion is preferable to a precise computation of ore tons only, which is common in the literature. But it is plainly necessary that the converted figure, i.e. the ore's average iron content, should always be taken into account. ${ }^{3}$ )

In addition to the reservations which have been mentioned yet another observation must be made. This concerns the actual source for the statistical account given below. The figures to be found in printed as well as unprinted accounts in fact very seldom tally with one another. The reason for this is to be found in the different ways of collecting the information, varying definitions of products and regions, et cetera. ${ }^{4}$ ) Thus the information given here about quantities does not claim to be exact or definitive. Where different sources show significant discrepancies with regard to a particular matter this will of course be noted below.

\section{B. The period up to the outbreak of war}

\section{The supply of domestic iron ore}

In the Treaty of Versailles after the first world war Germany had lost her main sources of iron ore to France, viz. the deposits of minett ore in Lorraine. The German production of iron ore in the 1920s was therefore on a much smaller scale than during the period before 1914 . In addition the iron ores which were mined here and there in Germany invariably had a low iron content, on average just over $30 \%$. The

$\left.{ }^{3}\right)$ See for example the different information about quantity in Karlbom (1965), p. 89, Milward (1967), pp. $130 \mathrm{ff}$. and Jäger (1969), p. 180. The difficulty of determining the iron ore content in a country's total iron ore production is obviously due to the fact that this is composed of a range of different ore qualities with different iron contents. As an example it can be stated that the Swedish iron ore (piece-ore) during the years just before the outbreak of the war had an average iron content of just over $60 \%$. During the war years the average content fell to about $57.5 \%$ at the lowest. The iron content of the ore concentrate and the briquettes was somewhat higher. SOS: Bergshantering 1936-1944. The problems have been discussed by Jäger (1969), p. 131.

${ }^{4}$ ) This difficulty was already apparent to commentators at the time, e.g. Friedensburg, F., Die deutsche Roh- und Treibstofflage, T77:214:951572 (N A). 
insignificant deposits combined with the low iron content meant that the degree to which Germany was self-supporting, i.e. the native production in relation to the steel industry's total consumption of iron ore, was low, just over $20 \%$. This meant that nearly $80 \%$ of the iron ore consumed in the German blast furnaces consisted of imported ore, all calculated in tons of iron. Of the larger countries of the world only Japan and Italy were self-supporting to a lesser extent.

The large imports naturally strained the German balance of payments. However, for the new German leaders in the 1930s the small extent to which Germany was self-supporting was more alarming from another point of view. A tense political situation or a war could lead to a cut in foreign deliveries which could rapidly bring Germany to her knees. But a stockpiling, however large, could not make up for the loss of the imports. Therefore the supply of iron ore was considered to be the Achilles heel of the German steel industry. ${ }^{5}$ )

Therefore within the framework of the German four-year plan a very great effort was made to increase the mining of iron ore within the boundaries of Germany, above all in newly opened mines in the Salzgitter area (east of Hanover) and in southern Germany (Dogger-ores). The aim of the substantial investments which took place was to raise the level to which Germany was self-supporting as much as possible. ${ }^{6}$ ) However the concept of being completely independent of foreign iron ore was one which only found expression in the context of propaganda. ${ }^{7}$ )

\footnotetext{
${ }^{5}$ ) There was a rich flowering of metaphors to illustrate the importance of the German imports of iron ore. Von Grundherr on one occasion coined one of the most descriptive ones in Auswärtiges Amt. There he warned Sweden about 'pressing on the inflamed sciatic nerve'. Vpm 21/9 1938, H40Ct (UD A).

${ }^{6}$ ) Here there will be no further discussion of the substantial effort to increase the domestic ore and steel production which was being made in the government administration within the framework of the German Four Year Plan and which led to controversies between spokesmen for the steel industry and the bureaucracy. The literature on this is substantial. A highly partial contemporary author is Rheinländer, P., Die deutsche Eisen- und Stahlwirtschaft im Vierjahresplan (1939). A modern account of the background to the Four Year Plan and what it accomplished is Petzina, pp. 48-53, 102-108. There are also many interesting comments by Caroll, especially on pp. $93-105,122-139$.

$\left.{ }^{7}\right)$ See e.g. von Grundherr's explanation to Muhl, the Swedish naval attaché, of Göring's speech in Nuremberg on Germany's ability to be self-supporting with regard to the question of iron ore. Vpm 21/9 1938, H40Ct (UD A).
} 
Political and military opinion was of course in favour of the effort in question. Its economic consequences, viz. lower quality and dearer iron ore for the steel works along with impaired profitability and/or raised steel prices, were deliberately brushed aside by the politicians, in spite of the fact that the industry was sceptical of an increased use of native ores, both on economic and metallurgical grounds. ${ }^{8}$ ) A comparison between the costs of different ores is made in a later chapter (page 77).

The conscious effort to increase the native production of iron ore certainly led to a sharp rise in production during the latter years of the 1930s:

Table 12. Germany's production of crude ore 1928-1939

(1000 tons)

\begin{tabular}{|c|c|c|c|c|c|}
\hline Year & Tons of Ore & Tons of Iron & Year & Tons of Ore & Tons of Iron \\
\hline 1928 & 6475 & 2089 & 1934 & 4343 & 1372 \\
\hline 1929 & 6374 & 2081 & 1935 & 6044 & 1849 \\
\hline 1930 & 5741 & 1845 & 1936 & 7570 & 2259 \\
\hline 1931 & 2621 & 842 & 1937 & 9792 & 2759 \\
\hline 1932 & 1340 & 443 & 1938 & 12351 & 3360 \\
\hline 1933 & 2592 & 828 & 1939 & 14710 & 3928 \\
\hline
\end{tabular}

Source: Statistisches Handbuch von Deutschland 1928-1944, p. 281.

Note 1. Concentrated ore is included in the statistics, cf. Jäger (1969), p. 131.

${ }^{8}$ ) Hitler's views on the implementation of the policy, 'ohne Rücksicht auf die Kosten', are to be found in his Denkschrift, p. 209. In this connection it may also be of interest to give the views of the German industrialist Fritz Thyssen on the start of ore mining and steel production in Salzgitter, even if the evidence dates from 1945: '... When the Hermann-Göringwerke were started, the whole German industry was opposed because the HGW were built on ore deposits which had been found by my firm and the ore, from our experience, could not be used with success by putting it into the blast furnace alone. All the other works were of the same opinion with us and we made a meomorandum explaining that it was much too early to build big works on these deposits without knowing if Mr. Brassert pretended if the ore could be used alone for making pig-iron and steel. All the works were prepared to sign, but at 
The sharp rise in production was made partly through using ores with a lower iron content. The average iron content fell from about $32 \%$ at the end of the 1920 s to about $27 \%$ towards the end of the $1930 \mathrm{~s} .{ }^{9}$ ) This problem gives rise to further discussion later.

The table above only includes 'Altreich'. From October 1938 Austria's iron ore production ought to be included in 'Reich'. At the end of the 1930s the Austrian iron ore production had increased and in 1939 it rose to more than 2.7 million tons of iron ore, which meant 853,000 tons of iron. ${ }^{10}$ ) 'Reich's' total production would thus amount to $4,781,000$ tons of iron. This meant that the German production of iron ore had increased one and a half times again from 1935 to 1939.

\section{The imports of iron ore}

The imports of iron ore also rose sharply, even if not at the same rate as the home production. The level of self-support was therefore only raised slowly, and at the end of the 1930s there was a long way to go before the target set up in the middle of the decade was reached. The

the last moment two of them, Krupp and Mannesmann, received telegrams saying that if they signed the memorandum they would be treated as traitors, and consequently they did not sign. The memorandum could have been influential if all had signed, but of course if two of the most important works refused ... So the HGW were built with an enormous amount of money, some say $2 \frac{1}{2}$ billion Marks. And they could not work with the ore there, but had to introduce Swedish ore.' Interrogation of Dr. Fritz Thyssen 7/9-45, FD 3059/49 (IWM). On the opposition from the German steel industry, see also Petzina, pp. $103 \mathrm{ff}$., Caroll, pp. $145 \mathrm{ff}$, and on the 'peace treaty' between Reichswerke Hermann Göring and the steel works in the Ruhr, Eichholtz, p. 51.

$\left.{ }^{9}\right)$ Statistisches Handbuch von Deutschland 1928-1944, p. 281. The Salzgitter ore only had an iron content of about $20 \%$ and it was not until after concentration that the iron content reached 25-27\%. Industria, 1939, p. 392.

$\left.{ }^{10}\right)$ Bericht über den Steierischen Erzberg, Reichswirtschaftsministerium, R7VII:129 (B A). The annexation of Austria meant '... eine erfreuliche Erleichterung der Rohstoffversorgung. An erster Stelle sind hier die Österreichischen Eisenerzlager in Steiermark und Kärnten'. Die Bedeutung der Österreichischen Volkswirtschaft für das deutsche Reich, OKW, WiRüAmt, T77:411:1267070 (N A). 
apportionment of imports as between the various countries is shown in the following table:

Table 13. Germany's imports of iron ore 1935-1939

(1000 tons of iron content)

\begin{tabular}{rrrrrrrrrr}
\hline Year Sweden Norway France Luxem- Spain French Spanish \\
burg
\end{tabular}

Source: Statistisches Jahrbuch für das Deutsche Reich 1938. United States Bombing Survey, p. 247.

Note 1 . The conversion from tons of ore into tons of iron has been made using the following simplified calculations of the average iron content of iron ores: Sweden and Norway $60 \%$, France and Luxemburg $30 \%$, Spain $50 \%$, French North Africa $45 \%$, Spanish North Africa $55 \%$ and Other Countries $40 \%$. Cf. the qualification above, p. 29 .

As is shown, the imports increased sharply, above all from the Scandinavian countries and those outside Europe, while the deliveries from France and Spain stagnated. The relative contributions of the delivering countries are shown in the following table:

Table 14. Germany's imports of iron ore 1935-1939

$(\%)$

\begin{tabular}{|c|c|c|c|c|c|c|c|c|c|}
\hline Year & Sweden & Norway & France & $\begin{array}{l}\text { Luxem- } \\
\text { burg }\end{array}$ & Spain & $\begin{array}{l}\text { French } \\
\text { North } \\
\text { Africa }\end{array}$ & $\begin{array}{c}\text { Spanish } \\
\text { North } \\
\text { Africa }\end{array}$ & $\begin{array}{l}\text { New- } \\
\text { found- } \\
\text { land }\end{array}$ & $\begin{array}{c}\text { Other } \\
\text { Coun- } \\
\text { tries }\end{array}$ \\
\hline 1935 & 51.6 & 4.8 & 26.3 & 1.7 & 10.3 & 1.5 & - & 1.5 & 2.2 \\
\hline 1936 & 58.5 & 3.7 & 24.3 & 2.0 & 6.3 & 2.8 & - & 1.0 & 1.4 \\
\hline 1937 & 59.1 & 3.3 & 18.7 & 5.0 & 1.7 & 3.6 & - & 4.4 & 4.2 \\
\hline 1938 & 52.1 & 6.5 & 14.6 & 5.1 & 5.2 & 3.3 & 3.8 & 5.4 & 3.9 \\
\hline 1939 & 60.3 & 6.0 & 8.0 & 4.6 & 3.6 & 4.3 & 2.5 & 4.0 & 6.7 \\
\hline
\end{tabular}

Source: See the previous table. 
Thus Sweden was the most important delivering country and her proportion was maintained throughout the period. Its importance justifies a closer examination of the Swedish exports. First, however, German's imports from other countries will be discussed.

German imports of iron ore from France constituted only a minor part of the French production of iron ore, and consisted mainly of minett ore with a comparatively low iron content, which was used above all in the blast furnaces of the Saar. ${ }^{11}$ ) Imports from France stagnated during the period and her comparative proportion declined in consequence. With the outbreak of war at the beginning of September 1939 French deliveries of iron ore naturally ceased completely.

Spain had for a long time been a substantial exporter of low phosphorous content grades of ore both to Great Britain and to Germany. The total Spanish export, which was about 5.6 million tons of iron ore in 1929, fell considerably during the Spanish civil war. In 1935 the total export amounted to 1.9 million tons and in 1937 to only 0.9 million tons. ${ }^{12}$ ) Germany tried to use her political connections with the victorious Franco regime and the Spanish national debt to Germany in order to acquire and make substantial investments in Spanish iron ore mines to secure and increase continuous imports. ${ }^{13}$ ) However the German efforts had not led to any significant results even by the time war broke out. ${ }^{14}$ )

The uncertain imports of iron ore from Spain made Germany try to find new suppliers from further afield. As far as quantity was concerned delveries from deposits in Algeria, Tunisia and Morocco could

11) In 1938 the blast furnaces in the Saar area consumed 5.2 million tons (tons of ore) of iron ore. Of these, 4.3 million tons came from France, which in turn constituted over $80 \%$ of the total of French exports of iron ore to Germany. Der Bezug der Deutschen Hochofen und Stahlwerke an Eisen- und Manganerzen 1938, Reichswirtschaftsministerium, Wirtschaftsgruppe Eisen schaffende Industrie, T71:14:404616 (N A).

${ }^{12}$ ) Die Wirtschaftsstruktur Spaniens, OKW WiRüAmt, T84:134:1437023 ff., T84:135:1437139 f. (N A).

$\left.{ }^{13}\right)$ Entstehung, Entwicklung und gegenwärtiger Stand des Rowak/SofindusKonzerns, R7VII:140 (B A). AzDAP, Bd DIII, pp. 423 ff., 464. See also Van der Esch, p. 13, Merkes, M., pp. 26, $128 \mathrm{ff}$.

${ }^{14}$ ) In actual fact the German organisation in Spain only acquired a lot of worthless mines and mining claims. Entstehung, Entwicklung und gegenwärtiger Stand des Rowak/Sofinduskonzerns, R7VII:140 (B A). 
compensate for the loss of the Spanish ores. The German hunger for ore also reached the other side of the Atlantic. During the second half of the 1930s growing quantities of iron ore were imported from Newfoundland.

The fact that Sweden was responsible for half of Germany's total imports of iron ore naturally made that country of special interest to the German steel industry and thus also to the German political leaders. The interest in Sweden was also accentuated for other reasons. For her part Germany assumed that France if she were in a critical situation or at war would instantly cut off her deliveries of iron ore to Germany. Great Britain, by virtue of her military superiority at sea, could also cut off the more significant imports from North Africa and Newfoundland as well as the Norwegian deliveries across the North Sea. Finally, the imports from Spain had diminished alarmingly.

Against the background of the very unsatisfactory level of selfsupport and the unwillingness or inability of the other exporting countries to keep up deliveries in wartime conditions the well-documented interest in Swedish iron ore is understandable, and in 1937 it led to an 'offensive' against Sweden by Germany and England simultaneously to get her to increase deliveries of iron ore to each country respectively. This 'offensive', which has been noted earlier in the literature, was pursued both on a commercial and a political level. ${ }^{15}$ ) The latter was in itself natural, bearing in mind that the Swedish state owned half of the two largest Swedish iron ore mines, Kiruna and Gällivare, and also regulated by Government agreements the volume of exports from these two mines and the next largest in Grängesberg.

Thus it was Germany's obvious uneasiness over the country's future supply of iron ore which led to a request for increases in the deliveries of iron ore and a change in the Government agreement. This uneasiness was of course increased by the general boom with its accompanying shortage in the supply of steel, and above all by the currently growing interest of the English in Swedish iron ore.

The English request for increased deliveries also had to a certain extent a background of changes in the international structure of the trade in iron ore. At the same time as this demand for steel rose sharply-

$\left.{ }^{15}\right)$ Hägglöf, pp. 21 ff., Meinander, pp. 229, 238 ff. Hermann Göring was involved on the German side, and Runciman, the President of the Board of Trade, on the English side. 
reinforced by the armament programme-the ever reducing Spanish deliveries caused serious problems for England.

In addition the English blast furnaces went over to the Thomas method of pig-iron production on a growing scale, and in so doing their interest in Swedish phosphorous ores increased. The Germans also susspected that the increased English demand was dictated by a desire thus to reduce the Swedish shipments of iron ore to Germany. ${ }^{16}$ ) The suspicion of Germany was also directed towards Sweden. The increased exports to England, which were at first considered a natural commercial spreading of risk on the part of the ore sellers in Sweden, were now looked upon as influenced by considerations of foreign policy. It was also considered serious by the Germans that the increase in the export quantities-in order to be passed in the Swedish Parliament - had to be attended by a desire to be able to export more to England. ${ }^{17}$ )

During this 'offensive', which can be regarded as a prelude to the coming of the iron ore problem, and Sweden being confirmed in the role allotted to her, she was put under pressure which led to the alteration of the Government agreement. Thus it was made possible to increase exports to Germany as well as Great Britain. Because of the trade slump in the following years the quantities assigned to Great Britain were not collected in full, but instead were allotted-at least in partto the German steel industry. ${ }^{18}$ )

$\left.{ }^{16}\right)$ Deutsche Gesandtschaft, Stockholm to Auswärtiges Amt 6/10 1936, 15/1,18/3 1937, HaPol Schweden Eisenerz Bd 2 (AA), Trafikaktiebolaget Grängesberg-Oxelösund styrelseprotokoll 7/4 1937 (G A), Brewett t. Vererker 27/4-37, N2247/1509/42 (P R O).

$\left.{ }^{17}\right)$ Aufzeichnung 19/1 1938, Die deutschen Erzbezüge aus Schweden, HaPol Schweden Eisenerz Bd 2 (A A). The fact that the proceedings in parliament were delicate is evident from a piece of advice from the trade councillor Vinell in Berlin to the Germans, not to press the question too far in official circles, because the Swedish government would then have difficulties in forcing it through because of increased opposition in Sweden, from the press inter alia. Vermerk 18/1 1937, HaPol Schweden Eisenerz Bd 2 (A A). German apprehension was made more intense by the fact that the management of Grängesberg was considered markedly well disposed towards England, or as the German envoy expressed it in a report to Berlin, ‘. . dass wir bei der Leitung des massgebenden schwedischen Erzunternehmens Grängesberg $\mathrm{AB}$ keine gefühlsmässige Sympathie für unsere Interessen sondern eher eine ausgesprochene Hinneigung nach England vorauszusetzen müssen'. Deutsche Gesandtschaft to Auswärtiges Amt 18/3 1937, HaPol Schweden Eisenerz Bd 2 (A A).

${ }^{18}$ ) Out of $2,533,000$ tons contracted to Great Britain only $1,482,000$ tons were collected, PM 28/3 1939, H40Ct (UD A). Trafikaktiebolaget Grängesberg-Oxelösund styrelseprotokoll 12/4 1938, 25/11 1938 (G A), Söderblom to Prytz 14/7-38, H40 $\mathrm{Ba}$ (UD A). 
As a further example of the uncertainty which was felt in Germany during the spring of 1939 , mention may made of a proposal which was put to the Trafikaktiebolaget Grängesberg-Oxelösund concerning the possibility of storing a million tons of ore in the Ruhr, which were to be owned by Sweden although the buyers had paid the freight as well as the interest charges. As a justification for this a request was made for access to Swedish iron ore in the event of a sudden cut in deliveries. However the proposal was never put into effect, obviously for political reasons..$^{19}$ )

What was the assessment, on the German side, of the chances of obtaining iron ore from Sweden if there was a state of war? The question was certainly not one of little significance, but it was more difficult to answer than, e.g. the question about deliveries from France or North Africa.

There was hardly the fear-even if it was sometimes expressed-that Sweden would cut off her exports of ore for political reasons or-even worse-have them transferred to Great Britain. During the summer of 1939 the English planned purchases in Sweden, not primarily because their own steel works were in dire need of Swedish ore, but rather in order to reduce the shipments to Germany. ${ }^{20}$ ) Repeated assurances from the Swedish politicians indicated that there would be a continuous delivery of 'normal' quantities, which was considered consistent with Sweden's policy of neutrality. ${ }^{21}$ ) The English superiority at sea made the German observers realise that the substantial shipments from Narvik, which constituted at least half of Sweden's total exports of iron ore in the latter years before the war, could hardly be maintained in full in the event of a war. There was a doubt about the extent of this reduction and whether there would be a total stoppage. However reliance was placed on a substantial part of the traditional shipping of Narvik instead being routed to the Baltic port of Luleå, in spite of the fact that this port, as distinguished from Narvik, was frozen up for half the year.

\footnotetext{
19) Trafikaktiebolaget Grängesberg-Oxelösund styrelseprotokoll 20/3 1939, 15/6 1939 (G A).

$\left.{ }^{20}\right)$ Prytz to Sandler 27/4 1939, 1/5 1939, Prytz to Hägglöf 13/7 1939, H40Ct (UD A).

${ }^{21}$ ) Richert to utrikesministern 18/4 1939, H40Ct (UD A). Hägglöf pp. 14 ff.
} 
A reduction of about 3 million tons (tons of ore) was forecast in a report in January $1939 .{ }^{22}$ )

This made the question of transport across the Baltic of even more vital importance. As long as the Germans saw the Soviet Union as a threat transport across the Baltic remained insecure. If at the outbreak of war the Soviet Union was numbered among Germany's enemies, the Germans did not believe that they would be able to maintain the imports from the north of Sweden. ${ }^{23}$ ) However in the context of improving relations between Germany and the Soviet Union during the summer of 1939 Germany's shipping position also improved, and with the planning of alternative 'Mob-Falls', the forecast for the German steel industry as regards the question of her iron ore supply was a much brighter one. ${ }^{24}$ )

\section{Summary}

The great effort to bring about a sharp increase in the national production of iron ore in Germany led during the latter part of the 1930s to a raised level of self-support, which was further improved by the incorporation of Austria into 'Reich'. The rate of increase was however a slow one. The following tables provide information about the total supply of iron ore in Germany during the second half of the 1930s.

\footnotetext{
${ }^{22}$ ) In the years 1936-1939 over 2.5 million tons of ore a year were shipped from Luleå. Sammandrag av Luleå leveranser (Summary of Luleå deliveries) (G A). The Germans calculated that Luleå had an annual capacity of about 4.5 million tons. Vermerk 20/1 1939, HaPol Schweden Eisenerz Bd 2 (A A). In this connection it can be said that even the Swedes estimated Luleå's normal capacity at 4 million tons. By the use of small technical devices it was possible to ship 5 million tons. PM 28/3 1939, H40Ct (UD A).

${ }^{23}$ ) Reichsamt für wehrwirtschaftliche Planung, Der deutsche Aussenhandel im Kriegsfall. T84:195:1561347 (N A), OKW WiRüAmt, Die Eisenerzversorgung Deutschlands im Kriege, 28/2 1939, T77:701:1913702 ff. (N A).

${ }^{24}$ ) OKW WiRüAmt, Entwurf 28/6 1939, T77:701:1913675 (N A). During the spring of 1939 the German steel industry operated on the basis of two alternative 'Mob-Programs', one in which Swedish deliveries were pre-supposed to have stopped, and the other in which they were assumed to have continued. Eisenwirtschaft seit Kriegsausbruch, pp. 14 ff., R10III:6 (B A).
} 
Table 15. Germany's iron ore supply 1935-1939

(1000 tons iron content)

\begin{tabular}{|c|c|c|c|c|c|c|c|}
\hline \multirow[t]{2}{*}{ Year } & \multicolumn{3}{|c|}{ Domestic production } & \multicolumn{3}{|c|}{ Imports } & \multirow[t]{2}{*}{ Total } \\
\hline & 'Altreich' & $\begin{array}{l}\text { Rest of } \\
\text { 'Reich' }\end{array}$ & Total & Sweden & $\begin{array}{l}\text { Other } \\
\text { Imports }\end{array}$ & Total & \\
\hline 1935 & 1849 & - & 1849 & 3305 & 3098 & 6403 & 8252 \\
\hline 1936 & 2259 & - & 2259 & 4949 & 3518 & 8467 & 10726 \\
\hline 1937 & 2759 & - & 2759 & 5450 & 3767 & 9217 & 11976 \\
\hline 1938 & 3360 & - & 3360 & 5395 & 4970 & 10365 & 13725 \\
\hline 1939 & 3928 & 853 & 4781 & 6226 & 4092 & 10318 & 15099 \\
\hline
\end{tabular}

Source: See previous tables.

Table 16. Germany's iron ore supply 1935-1939

$(\%)$

\begin{tabular}{|c|c|c|c|c|c|c|c|}
\hline \multirow[t]{2}{*}{ Year } & \multicolumn{3}{|c|}{ Domestic production } & \multicolumn{3}{|c|}{ Imports } & \multirow[t]{2}{*}{ Total } \\
\hline & 'Altreich' & $\begin{array}{l}\text { Rest of } \\
\text { 'Reich' }\end{array}$ & Total & Sweden & $\begin{array}{c}\text { Other } \\
\text { Imports }\end{array}$ & Total & \\
\hline 1935 & 22.4 & - & 22.4 & 40.1 & 37.5 & 77.6 & 100.0 \\
\hline 1936 & 21.1 & - & 21.1 & 46.1 & 32.8 & 78.9 & 100.0 \\
\hline 1937 & 23.0 & - & 23.0 & 45.5 & 31.5 & 77.0 & 100.0 \\
\hline 1938 & 24.5 & - & 24.5 & 39.3 & 36.2 & 75.5 & 100.0 \\
\hline 1939 & 26.0 & 5.7 & 31.7 & 41.2 & 27.1 & 68.3 & 100.0 \\
\hline
\end{tabular}

Source: Table 15.

Thus the German iron ore situation during the end of the 1930s was not satisfactory if complete self-support was desired above all. As far as steel production was concerned the great dependence on other countries constituted a threat, as most of the delivering countries could be expected to cut off deliveries if war broke out. However the most important delivering country, Sweden, was prepared to continue her exports on a normal scale in the event of war breaking out. Therefore the deliveries to Germany became mainly a question of transport and in the last resort a question of whether it was possible to ship iron ore across the Baltic. 
Without in this connection going into the various reasons for the Soviet-German pact at the end of August 1939 and its consequences, one result should be established here and now: the Baltic acquired the character of a German sea. ${ }^{25}$ ) Thus at a single stroke a radical improvement took place in the German supply situation. Through political decisions the imports from Sweden now seemed assured for a long time to come.

\section{The first year of the war (September 1939-June 1940)}

\section{The supply of domestic iron ore}

German iron ore production, which was already growing sturdily and continuously before the outbreak of war, went on expanding during the autumn of 1939 and the spring of 1940 at an increased rate, mainly thanks to the mining which had started at the Salzgitter mines. ${ }^{26}$ ) The development of production is shown in the following table:

Table 17. German iron ore production 1938-1940

(1000 tons of iron)

\begin{tabular}{|c|c|}
\hline 1938 , quarterly average & 840 \\
\hline 1939 , quarterly average & \\
\hline of 1 st and 2 nd quarters, & 1103 \\
\hline 1939,3 rd quarter & 1174 \\
\hline 1939,4 th quarter & 1315 \\
\hline 1940,1 st quarter & 1184 \\
\hline 1940,2 nd quarter & 1471 \\
\hline
\end{tabular}

Source: Previous tables, and information from Planungsamt, printed in Milward (1967), pp. $130 \mathrm{ff}$.

\footnotetext{
${ }^{25}$ ) The protection of the Baltic became one of the most important tasks for the German navy. Hitlers Weisungen für die Kriegführung 1, 31/8 1939. In September the English were harbouring some hazardous plans for invading the Baltic. Starck, I, pp. $115 \mathrm{f}$.

${ }^{26}$ ) Production in Salzgitter rose from 86,000 tons (of ore) in August 1939 to 418,000 tons in June 1940. Friedensburg T:77:214:951586 (N A).
} 
From the year 1939 to the year 1940 production rose in 'Altreich' by $28 \%$ to a total of $5,019,000$ tons of iron, while production in Austria as a whole was on the same level as in previous years. ${ }^{27}$ ) Besides, the year 1940 became the best year from the point of view of production during the whole of the period under examination.

There is a natural explanation for the sharp increase in production after the outbreak of war. For reasons which have been mentioned earlier and which will be further explained below, German imports of iron ore decreased considerably, and therefore increased demands were made on domestic production in order to keep the steel industry going. Several factors dictated that the expansion was still relatively limited. ${ }^{28}$ ) The general shortage of labour also affected the mining industry. The insufficient means of transport of a Germany at war prevented substantial carriage of domestic iron ore, and finally the cold winter of 1940 caused a general decline in production. Pig-iron from ores of low iron content also required, comparatively, much coke and labour. There was a widespread shortage of both of these in Germany at the relevant time. Finally, the actual capacity of the blast furnaces precluded too substantial a use of the poorer ores. Because of this, imports of ores with a high iron content remained vital for the German steel industry.

\section{The imports of iron ore}

As regards imports the development immediately after the outbreak of war was as predicted. Imports from France ceased, as did the greater part of the imports of ore which came across the Atlantic. The loss has been estimated at $36 \%$ (according to the iron content) of the normal pre-war imports. ${ }^{29}$ ) As far as exports from Sweden were concerned shipments via Narvik were reduced but could be kept going in the shelter of Norwegian territorial waters.

$\left.{ }^{27}\right)$ Statistisches Handbuch von Deutschland 1928-1944, p. 281.

${ }^{28}$ ) Here there will be a reference once and for all to another examination of the period September 1939-June 1940 by the author. Fritz (1973), p. $133 \mathrm{ff}$.

$\left.{ }^{29}\right)$ Jäger (1969), p. 171. 
Table 18. Shipments from Narvik, September 1939-April 1940

(1000 tons of ore)

Corresponding shipments for the previous year in brackets

$1939 \begin{array}{lllllll}\text { Sept. } & 165 & (462) & 1940 & \text { Jan. } & 511 & (609) \\ \text { Oct. } & 227 & (418) & & \text { Feb. } & 290 & (587) \\ \text { Nov. } & 249 & (418) & & \text { March } & 376 & (724) \\ \text { Dec. } & 294 & (464) & & \text { April } & 168 & (687)\end{array}$

Source: Sammandrag av Narviksleveranser (Summary of Narvik deliveries) (G A).

More important than the deliveries from Narvik, however, were shipments from Luleå across a Baltic protected from enemies. These in fact rose to an extent which the Germans, for their part, had hardly dared to count on. The satisfaction over this was just as striking in Germany as the annoyance which it provoked in England: ${ }^{30}$ )

Table 19. Shipments from Lulea in the autumn of 1939

(1000 tons of ore)

Previous year's shipments in brackets

\begin{tabular}{llll}
\hline 1939 & Sept. & 592 & $(374)$ \\
& Oct. & 579 & $(230)$ \\
& Nov. & 514 & $(155)$ \\
& Dec. & 186 & $(-)$ \\
\hline
\end{tabular}

Source: Sammandrag av Luleåleveranser (Summary of Luleå deliveries) (G A).

Since the shipments from the next largest shipping port on the Baltic, Oxelösund, were also almost twice as high $(519,000$ tons for SeptemberDecember 1939, compared with 286,000 tons for the corresponding period in 1938) German satisfaction is very understandable. However, with the closure of the port of Luleå due to ice barriers, the supply decreased substantially during the first half of 1940:

\footnotetext{
${ }^{30}$ ) In a memorandum of September 1939 about the supply of steel the Germans reckoned on a yearly delivery of about 3.2 million tons (tons of ore) from North Sweden. OKW WiRüAmt, Versorgung mit Eisen und Stahl 17/9 1939, T77:367:1210648 (N A). During the period September-December 1939 alone 2.8 million tons (tons of ore) were shipped from Luleå and Narvik. Thomas, pp. $180 \mathrm{ff}$., Medlicott,. p 145.
} 
Table 20. Germany's imports of iron ore 1938-1940 (1000 tons of iron)

\begin{tabular}{lrcc}
\hline \multicolumn{1}{c}{ Period } & Total & From Sweden & $\begin{array}{c}\text { Sweden's } \\
\% \text { of total }\end{array}$ \\
\hline 1938, quarterly average & 2591 & 1349 & 52 \\
1939, quarterly average of & & & \\
$\quad$ 1st and 2nd quarters & 2790 & 1481 & 53 \\
1939, 3rd quarter & 2753 & 1535 & 56 \\
1939, 4th quarter & 1711 & 1546 & 90 \\
1940, 1st quarter & 641 & 460 & 72 \\
1940, 2nd quarter & 867 & 789 & 91 \\
\hline
\end{tabular}

Source: See table 17.

As shown in tables 17 and 20 the total supply of iron ore to Germany decreased during the first six months of 1940 and a considerable use of stocks had to be made. However it has been established in other connections that a shortage of iron ore was hardly the reason for the drop in production which afflicted the steel industry in Germany in 1939/ $1940 .^{31}$ )

It is absolutely clear that the supply of Swedish iron ore-in spite of decreased deliveries in the spring of 1940-constituted a substantial contribution to the steel industry. It was therefore important that Sweden should be willing to continue her deliveries even when there was a state of war. ${ }^{32}$ ) Obviously Sweden had no choice. Germany's ability and desire to deliver important goods to Sweden were explicitly directly dependent on the Swedish deliveries of iron ore to Germany. ${ }^{33}$ ) On the other hand it is possible to discern a perceptible nervousness and uneasiness in Germany, and various rumours about the Swedish iron ore found expression in all sorts of ways. The sale of the Gränges-

31) Fritz (1973), p. 133.

${ }^{32}$ ) In a discussion within the Reichswirtschaftsministerium in the autumn of 1939 it was established that 'Schweden ist gewissermassen Exportland $\mathrm{Nr}$ 1. In diesem Land keine Versorgungsschwierigkeiten aufkommen lassen'. Besprechung im RWM 23/11 1939, T71:48:422364 (N A).

33) Right from the start of the war the Germans were ready and willing to supply Sweden with vital goods in connection with Swedish exports of iron ore. PM angående överläggningar rörande de svensk-tyska handelsförbindelserna (Memoranda concerning discussions on Swedish-German trade links) 26/9 1939, HP64Ct (UD A). On the role of Swedish iron ore in Swedish trade policy see below, chapter VI. 
bergsbolag to France in the autumn of $1939,{ }^{34}$ ) like the wish of the U.S.A. to purchase the whole of Sweden's exports of iron ore in order to deliver them to Britain, ${ }^{35}$ ) was however among the more imaginative.

The imports of iron ore from Sweden, which were important for Germany-though hardly indispensible from a short-term point of view-led to clear efforts by the allies to reduce, or rather completely cut off the Swedish deliveries. The planning of the allies as well as subsequent events in the north of Scandinavia have long been known to research, and so a short summary will be given here, together with some notes. ${ }^{36}$ )

English interest was focused mainly on Narvik, the importance of which was apparently overrated by the English. It appears that they did not take into account either the fact that Luleå was to manifest so great a latent shipping capacity during its short season. ${ }^{37}$ ) During the Russian-Finnish war in the winter of 1939/1940 however, there was a transformation in the possibilities of encroaching on the actual ore fields themselves in the north of Sweden. An allied rescue expedition on a limited scale was to be put ashore in Narvik, and was to march through the north of Sweden to the assistance of Finland. The sympathy for Finland's fight which was generally widespread in Sweden would make the allied march through Sweden easier from the point of view of public opoinion. The main task of the expedition was in fact to gain control of the Swedish ore fields of Kiruna and Gällivare which accounted for the major part of the Swedish exports of ore to Germany. The planning of the allies was stimulated by the exiled German industrialist Fritz Thyssen who made highly exaggerated pronouncements to the effect that victory would go to the side which won control over the Swedish iron ore. In the English Cabinet it was reckoned in January

${ }^{34}$ ) The Swedish embassy in Berlin to Utrikesdeparterıentet 7/10 1939, H40Ct (UD A).

${ }^{35}$ ) OKW WiRüAmt, Aktenvermerk 2/11 1939, T77:430:1293155 (N A).

${ }^{36}$ ) The latest work is by Woodward, whose report follows War Cabinet Conclusions (P R O) closely. See also Wahlbäck, pp. $250 \mathrm{ff}$., Synnergren, pp. $184 \mathrm{ff}$., Carlgren, pp. $81 \mathrm{ff}$.

${ }^{37}$ ) Boheman, pp. 13, 87, 115. As mentioned above, note 22, in January 1939 the Germans estimated Luleå's capacity at 4 million tons a year. In actual fact during the year 1940 no less than 5.1 million tons were exported from this port. Sammandrag av Luleåleveranser (Summary of Luleå deliveries) (G A). That this was possible is due to the fact that the Swedes tried in every way to make deliveries easy. Memorandum 26/6 1941, HP64Ct (UD A). 
1940 that a cut in the deliveries of iron ore from the north of Sweden would bring Germany to her knees within a year. ${ }^{38}$ )

The English-French initiative met with opposition from Norway and Sweden to a march overland. Passive permission at least was considered to be a necessary condition for the action's prospects of success. In addition considerable doubt arose in the English government as to the action's consequences in various fields (e.g. that the German countermeasures would succeed). The risk that they themselves might lose deliveries of iron ore in an action against Narvik served to increase the doubts. ${ }^{39}$ )

The allies ambitions to stop Swedish exports of iron ore finally resulted - on 8 April 1940 - in the laying of mines outside Narvik and in the rest of the Norwegian territorial waters. But at that time Operation Weserübung was almost completed.

The plans of the allies to stop German imports of iron ore by using Finnish support as a battering-ram became known early on in Germany, and counter-measures were being prepared. ${ }^{40}$ ) There has been discussion in scientific literature as to whether the German attack on Norway was a 'defensive' act, i.e. done to prevent a cut in the imports of ores, or an 'offensive' operation designed to facilitate the attack which had been planned against Great Britain. ${ }^{41}$ ) Obviously the two motives cannot be kept quite distinct.

In this connection only a few observations will be made. As shown above, the allies' superiority at sea had not cut off the Swedish deliveries of iron ore to Germany. Instead shipments across the Baltic showed a

${ }^{38}$ ) Thyssen's statement, see Woodward, p. 50. An English Member of Parliament told the Swedish envoy in London that a cancellation of the shipments of Swedish ore to Germany would bring the war to an end within six months. Prytz to Sandler 8/9 1939, H40Ct (UD A), the view of the War Cabinet, see War Cabinet Conclusions 2/1-40 (P R O). However it was acknowledged that great risks were involved in such an action. The importance which attached to Swedish iron ore in fact justified the taking of great risks. War Cabinet Conclusions 20/12-39, 17/1-40 (P R O). However on a few occasions reservations were made about the importance of Narvik, e.g. the President of the Board of Trade in War Cabinet Conclusions 10/1-40 (P R O).

${ }^{39}$ ) It was emphasised that Great Britain's imports of iron ore from Sweden almost invariably went via Narvik. War Cabinet Conclusions 10/1, 12/1-40, (P R O), Eden to Halifax 10/1-40, N534/19/63, Foreign Office Minute 28/1-40, N2570/19/63, Collier Memorandum 7/3-40, N2815/9/56 (P R O).

$\left.{ }^{40}\right)$ E.g. AzDAP, Bd DVIII, pp. 510, $520 \mathrm{ff}$.

$\left.{ }^{41}\right)$ Gemzell, pp. 7 ff. Cf. Tägil, p. 214. 
considerable increase, and German satisfaction over this was plain. For the defensive interpreatation to be valid, not only would minelaying by the allies outside Narvik be called for but above all there would have to be a capture of the actual ore fields and the harbour of Luleå. After the peace treaty of 12 March 1940 between Finland and the Soviet Union such action could hardly any longer be politically motivated, and besides it would have led to Sweden being thrown into the arms of Germany. The mine-laying which finally took place could therefore hardly provide the motive for a German attack-any more than the mine-laying itself was economically motivated-since Luleå's shipping season was imminent. ${ }^{42}$ ) Destruction by the allies of the iron ore mines or of the harbours in Luleå and Oxelösund would then have constituted a much graver threat to the German iron ore supply. The English did not seem to expect a German attack in reprisal for the mine-laying. ${ }^{43}$ )

\section{Summary}

During the first year of the war the iron ore question came into focus in higher politics and helped to shape political events abroad. In this respect the English seem to have exaggerated Narvik's importance as a harbour for shipping, or rather to have failed to appreciate the extent of Luleå's latent potential. The theory that the German attack on Norway was dictated above all by the country's need for iron ore hardly seems plausible.

As a consequence of foreign political and military events iron ore deliveries from Sweden continued in a stabilized way. The shipments from Narvik ceased during the whole of the year 1940 and the ore had to be diverted to an increased extent via Luleå, whose exports, thanks to Swedish cooperation, were able to be substantially extended. Greater Germany became the only buyer of Swedish iron ore, and

\footnotetext{
$\left.{ }^{42}\right)$ Both the Swedes and the Norwegians put this point of view to the allies and to Germany, in order to avoid, if possible, an intervention in Narvik. Günther and Söderblom to Richert 2/4 1940, H40Ct (UD A), see also Bröyn, p. 113, Carlgren, p. 139.

${ }^{43}$ ) Woodward, p. 112. An 'operation Paul' directed against the shipping from Luleå by mine-laying from the air was being prepared in May 1940. To a great extent the material on this is not yet available, but see Memorandum by the First Sea Lord, N5798/19/63 (P R O). At the same time the possibility was being canvassed in the Foreign Office of offering Sweden economic compensation for destruction by the Swedes of the iron ore mines, Harris to Mallet 10/4-40, N5299/19/63 (P R O).
} 
thenceforth the allies were only able to bring about marginal interruptions of the ore shipments from Sweden, e.g. through the sinking of ships.

Sweden's role during this period was a fairly passive one, and her dependence on Germany increased. In the trade agreements which were made between the two countries iron ore deliveries of 10 million tons were provided for (in 1937 and 1938 exports had amounted to about 9 million tons). ${ }^{44}$ )

\section{The German iron ore supply during the war years}

\section{The domestic production of iron ore}

As shown in the previous section production in the German mines was intensified after the outbreak of war and reached record figures in 1940. With the conquest of France and the supply of minett ore, the domestic supply of iron ore, i.e. within 'Altreich', became less indispensable. Production stagnated and showed a downward tendency during the war years. Mining even stopped in certain newly dug mines (Dogger).

Table 21. The iron ore production of Germany ('Altreich') 1940-1944 (1000 tons)

\begin{tabular}{lcc}
\hline Year & Tons of ore & Tons of iron \\
\hline 1940 & 19204 & 5019 \\
1941 & 18119 & 4755 \\
1942 & 15341 & 4137 \\
1943 & 15208 & 4080 \\
1944 & 10137 & 2636 \\
\hline
\end{tabular}

Source: Statistisches Handbuch von Deutschland 1928-1944, p. 281. For the year 1944, p. 283 , with the iron content estimated to $26 \%$.

The stagnation within 'Altreich' was compensated for by a large production within 'Reich', resulting above all from the conquest of France and Luxemburg. The German need for iron ore does not in fact appear to have led to any immediate resumption of the offensive in the west. Milward, however, has seen a connection between the two, and has pointed out that the German dependence on Swedish iron ore could

\footnotetext{
${ }^{44}$ ) On Swedish trade policy see below, chapter VI.
} 
in the long run be troublesome for Germany, and that 'the possibility of an alternative source of supply made iron ore appear as the most valuable commodity which the French economy had to offer Germany' ${ }^{45}$ ) However the fact is-for various technical reasons, and in particular as confirmed by what actually happened-that the minett ore was hardly an immediately usable alternative to the Swedish iron ore, but was rather an alternative to the ore which was mined within 'Altreich'. ${ }^{46}$ )

The German conquest of France and Luxemburg brought about an increase in production within 'Reich':

Table 22. The production of iron ore within 'Reich' 1940-1944

(1000 tons of iron)

\begin{tabular}{ccccc}
\hline Year & 'Altreich' & Austria & France/Luxemburg & Total 'Reich' \\
\hline 1940 & 5019 & 865 & 1489 & 7373 \\
1941 & 4755 & 784 & 5176 & 10715 \\
1942 & 4137 & 771 & 5208 & 10116 \\
1943 & 4080 & 782 & 5920 & 11056 \\
1944 & 2636 & 900 & 3503 & 7846 \\
\hline
\end{tabular}

Source: 'Altreich': table 21, Austria: R7VII:129 (B A) and T71:17:407461 (N A), France/Luxemburg 1940-1942: Milward (1970), p. 215 converted above $30 \%$ iron content, 1943-1944: R3:1657B (B A), Total 'Reich' 1940$1942=$ the total of the various entries, 1943-1944: R3:1657B (B A).

Note 1. According to another source (Rohstoffbilanzen, Statistisches Reichsamt) the total production within 'Reich' amounted to 10,188,000 tons in 1942 and in 1943 to $10,884,000$ tons, T84:195:1561073 (N A).

\footnotetext{
${ }^{45}$ ) Milward (1970), p. 212. As to the French production of iron ore see Milward's work, the chapter entitled 'Iron Ore', pp. $210 \mathrm{ff}$.

${ }^{46}$ ) This interpretation is also made by Jäger (1969), pp. $180 \mathrm{ff}$. Clodius, one of the leading men in Auswärtiges Amt's trade policy department, contemplating Sweden in May 1940, says: 'Erz und Holz werden wir voraussichtlich auf absehbare Zeit noch in sehr grossem Umfange brauchen. Auch die Sicherung der lothringischen und nordfranzösischen Gruben als deutsche Bezugsquellen ... wird hieran nichts Grundlegendes ändern'. AzDAP, Bd DIX, pp. $392 \mathrm{f}$. At one of Speer's conferences with Hitler it was decided that the mining of iron ore should cease in Südbaden, since supplies were superabundant after the conquest of the Minett area. Deutschlands Rüstung, p. 76. Likewise it was thought that the German domestic iron ores compensated for the loss of the imports from France at the beginning of the war in 1939. OKW, WiRuAmt, Die Eisenerzversorgung Grossdeutschlands während der gegenwärtigen kriegerischen Verwicklungen, Dezember 1939, T84:195:1560535 (N A).
} 
Thus France and Luxemburg contributed at least half of the total production within 'Reich'. Probably the largest part of this production was also consumed by the blast furnaces within 'Reich' ${ }^{47}$ )

The German ('Reich') steel industry had of course the opportunity of making use of the iron ore which was mined in other conquered areas in 'Einflussgebiete'. In 'Einflussgebiete' too the French ore, especially from the departement of Meurthe-et-Moselle, played the most important role. $^{48}$ ) Deliveries from other areas were only occasional, or were of less importance.

Table 23. Iron ore mined in 'Einflussgebiete' and used in 'Reich' 1941-1944 (1000 tons of iron)

\begin{tabular}{|c|c|c|c|c|c|c|c|}
\hline Year & France & $\begin{array}{l}\text { French } \\
\text { North } \\
\text { Africa }\end{array}$ & Slovakia & Soviet & Norway & Others & Total \\
\hline 1941 & 2216 & 65 & 54 & - & 267 & 62 & 2664 \\
\hline 1942 & 2483 & 120 & 62 & 26 & 304 & 31 & 3026 \\
\hline 1943 & 2664 & - & 132 & 516 & 252 & 72 & 3636 \\
\hline 1944 & 983 & - & 72 & - & 119 & 56 & 1230 \\
\hline
\end{tabular}

Source: 1941-1942: R13I:532-533 (B A), 1943-1944: T84:195:1561073 (N A).

In order to obtain a more complete picture of the total iron ore production under German control it would of course be of interest to know also what the production was within 'Einflussgebiete'. However the statistical information about this is very uncertain. A rough estimate indicates that about half of the total iron ore production within 'Einflussgebiete' was delivered to steel works within 'Reich'. ${ }^{49}$ )

\footnotetext{
${ }^{47}$ ) Milward (1970), pp. $218 \mathrm{ff}$.

${ }^{48}$ ) On the allocation of France to 'Reich' and 'Einflussgebiete' respectively see Chapter I, p. 12.

${ }^{49}$ ) Statistische Handakte, Präsident Kehrl, R3:1657B (B A), Milward (1970), p. 222.
} 
On the basis of the information so far accounted for, 'Reich's' total supply of 'domestic' iron ore can now be compiled:

Table 24. 'Reich's' supply of 'domestic' iron ore 1940-1944 (1000 tons of iron and \%)

\begin{tabular}{lllllcrc}
\hline Year & \multicolumn{2}{c}{$\begin{array}{c}\text { 'Altreich' } \\
1000 \text { tons } \%\end{array}$} & \multicolumn{2}{c}{$\begin{array}{c}\text { Rest of 'Reich' } \\
1000 \text { tons } \%\end{array}$} & $\begin{array}{c}\text { 'Einflussgebiete' } \\
1000 \text { tons } \%\end{array}$ & $\begin{array}{c}\text { Total } \\
1000 \text { tons }\end{array}$ \\
\hline 1940 & 5019 & 68 & 2354 & 32 & - & - & 7373 \\
1941 & 4755 & 35 & 5960 & 45 & 2664 & 20 & 13379 \\
1942 & 4137 & 31 & 5979 & 46 & 3026 & 23 & 13142 \\
1943 & 4080 & 28 & 6702 & 47 & 3636 & 25 & 14418 \\
1944 & 2636 & 32 & 4403 & 53 & 1230 & 15 & 8269 \\
\hline
\end{tabular}

Source: Tables 21-23.

Thus during the war years the 'German' production of iron ore increased compared with the period at the end of the 1930s. The reason for this was mainly the conquest of France. Therefore the military successes contributed to a sharply increased level of self-support for 'Reich' as compared with pre-war 'Altreich'. However the raised level of self-support which is apparent is mainly a matter of book-keeping.

\section{The imports of iron ore}

By virtue of the fact that many countries which before the war had exported iron ore to Germany were integrated into 'Reich' or 'Einflussgebiete' total imports of iron ore obviously decreased. While the imports in 1938 had amounted to at least 10 million tons (tons of iron) during the war years they fell to about half:

Table 25. 'Reich's' imports of iron ore 1940-1944

(1000 tons of iron)

\begin{tabular}{lcccccc}
\hline Year & Sweden & Norway & $\begin{array}{l}\text { France/ } \\
\text { Luxemburg }\end{array}$ & Spain & Others & Total \\
\hline 1940 & 5339 & 74 & 281 & - & 311 & 6005 \\
1941 & 5027 & - & - & 126 & 172 & 5325 \\
1942 & 4205 & - & - & 359 & 447 & 5011 \\
1943 & 5568 & - & - & 192 & 72 & 5832 \\
1944 & 2628 & - & - & 53 & 30 & 2711 \\
\hline
\end{tabular}

Source: 1940: Statistisches Jahrbuch, 1941-1942: R13I:532-533 (B A), 1943-1944: T84:195:1561073 (N A). 
The imports from Spain during the war years never reached any significant quantities. Because of this Sweden became the totally dominant delivering country. Exports continued from there on the whole unaffected by foreign political events and no sudden changes in deliveries took place. It was the extent of the deliveries via Narvik which varied somewhat according to the strength of the navy. In 19410.7 million tons were shipped, in 1942 1.2, in 1943 2.0, and in 19441.1 million tons went via Narvik. In yearly trade agreements the quantities were fixed at 10 million tons (tons of ore) per year, but these were never collected in full. Thus the problems facing the importing of iron ore from Sweden were on a level different to that of foreign politics.

\section{Summary}

After the German military successes in Europe and above all by virtue of control over the French iron ore production, the German supply of iron ore formed a stable pattern. Production within 'Altreich' stagnated, while the French iron ores, those in 'Reich' as well as those in 'Einflussgebiete', became the dominant ones in supplying 'Reich'. Of the imported iron ores only those from Sweden were of importance:

Table 26. Germany's ('Reich') supply of iron ore 1940-1944 (1000 tons of iron)

\begin{tabular}{|c|c|c|c|c|c|c|c|c|}
\hline \multirow[t]{2}{*}{ Year } & \multicolumn{3}{|c|}{ Domestic production } & \multirow[b]{2}{*}{ Total } & \multicolumn{3}{|c|}{ Imports } & \multirow[t]{2}{*}{ Total } \\
\hline & 'Altreich' & $\begin{array}{l}\text { Rest of } \\
\text { 'Reich' }\end{array}$ & $\begin{array}{l}\text { 'Einfluss- } \\
\text { gebiete' }\end{array}$ & & Sweden & Others & Total & \\
\hline 1940 & 5019 & 2354 & - & 7373 & 5339 & 666 & 6005 & 13378 \\
\hline 1941 & 4755 & 5960 & 2664 & 13379 & 5027 & 298 & 5325 & 18704 \\
\hline 1942 & 4137 & 5979 & 3026 & 13142 & 4205 & 806 & 5011 & 18153 \\
\hline 1943 & 4080 & 6702 & 3636 & 14418 & 5568 & 264 & 5832 & 20250 \\
\hline 1944 & 2636 & 4403 & 1230 & 8269 & 2628 & 83 & 2711 & 10980 \\
\hline
\end{tabular}

Source: See previous tables. 
Table 27. Germany's ('Reich') supply of iron ore 1940-1944

(\%)

\begin{tabular}{|c|c|c|c|c|c|c|c|c|}
\hline \multirow[t]{2}{*}{ Year } & \multicolumn{3}{|c|}{ Domestic production } & \multirow[b]{2}{*}{ Total } & \multicolumn{3}{|c|}{ Imports } & \multirow[t]{2}{*}{ Total } \\
\hline & 'Altreich’ & $\begin{array}{l}\text { Rest of } \\
\text { 'Reich' }\end{array}$ & $\begin{array}{l}\text { 'Einfluss- } \\
\text { gebiete' }\end{array}$ & & Sweden & Others & Total & \\
\hline 1940 & 37.5 & 17.6 & - & 55.1 & 39.5 & 5.4 & 44.9 & 100.0 \\
\hline 1941 & 25.4 & 31.9 & 14.2 & 71.5 & 26.9 & 1.6 & 28.5 & 100.0 \\
\hline 1942 & 22.8 & 32.9 & 16.7 & 72.4 & 23.2 & 4.4 & 27.6 & 100.0 \\
\hline 1943 & 20.1 & 33.1 & 18.0 & 71.2 & 27.5 & 1.3 & 28.8 & 100.0 \\
\hline 1944 & 24.0 & 40.1 & 11.2 & 75.3 & 23.9 & 0.8 & 24.7 & 100.0 \\
\hline
\end{tabular}

Source: Table 26.

Did the political border changes mean that the supply situation for the steel works within 'Altreich' underwent some kind of change during the war years? For the years 1941-1942 the sources permit a comparison to be made with the pre-war period:

Table 28. 'Altreich's' iron ore supply in 1937 and 1941-1942 (tons of iron \%)

\begin{tabular}{|c|c|c|c|c|c|}
\hline \multirow[t]{2}{*}{ Year } & \multirow[t]{2}{*}{ 'Domestic supply' } & \multicolumn{3}{|c|}{ 'Imports' } & \multirow{2}{*}{$\begin{array}{l}\text { Total } \\
\text { tons of } \\
\text { iron }\end{array}$} \\
\hline & & Total & Sweden's share & France's share & \\
\hline 1937 & 23.0 & 77.0 & 45.5 & 14.4 & 11976 \\
\hline 1941 & 31.5 & 68.5 & 32.5 & 23.5 & 12784 \\
\hline 1942 & 31.7 & 68.3 & 36.1 & 19.9 & 13914 \\
\hline
\end{tabular}

Source: 1937: table 16, 1941-1942: R13I:532-533 (B A).

Thus the war years brought about certain changes in 'Alreich' iron ore supply. The domestic production showed a relative increase as did supplies from France, while the imports from Sweden decreased both relatively and absolutely. The changes can hardly be called fundamental, and the basic composition of the iron ore supplies in the steel works was unchanged. ${ }^{50}$ )

${ }^{50}$ ) Of the total Minett ore production (Lorraine, Luxemburg and Meurthe-etMoselle) in 1940-1944 of nearly 114 million tons (tons of ore) 14.7 million tons went to steel works in the Ruhr and 20.8 million tons to steel works in the Saar during these years. Milward (1970), p. 216. This meant a sharp rise in the consumption of this type of ore, especially in the Ruhr area. In 1938 the consumption of minett ore in the Ruhr area was only one-fifth of that in the Saar area, 1.1 million tons and 5.0 million tons respectively. T71:14:404615 (N A). 


\section{E. The end of the war}

The iron ore supply to the German steel works reached its maximum in 1943. Even during the first quarter of 1944 production was kept up around the level of the previous year's figures. After that there was a rapid decline..$^{51}$ )

The supply was reduced by the extensive bombing raids of the allies on the German steel industry and the German transport system. ${ }^{52}$ ) The military successes of the allies on land also of course meant a decrease in the deliveries from 'Einflussgebiete' and the rest of 'Reich'. The production of minett ore was reduced during the late spring and early summer to cease finally from the month of August onwards. ${ }^{53}$ )

The imports were also affected by the changes in foreign politics. During the autumn of 1943, when a new Swedish-German trade agreement for 1944 was being concluded, the Swedish negotiators were committed to a previous agreement with the Western Powers about a reduction in the quantities of exports, which were also reduced in the agreement from 10 million tons to 7 million tons. ${ }^{54}$ )

Under the pressure of the successes of the Western Powers the Swedish attitude hardened further. After pressure from the U.S.A. and Great

$\left.{ }^{51}\right)$ Reichswirtschaftsministerium, Hermann Röchling, Bericht über das I Quartal 1944, T71:34:428515 (N A).

52) The allied bombing raids began to take effect from the late summer of 1943 onwards. The transport system was bombed systematically from September 1944 and the steel works in the Ruhr from October. $80 \%$ of the fall in production in 'Reich' (from 2 million tons in September to barely 1 million tons in December) is ascribed to destruction by air raids. The United States Strategic Bombing Survey, pp. $11 \mathrm{ff}$,, $105 \mathrm{ff}$., the development of ingot steel production, ibid. appendix table 73 .

${ }^{53}$ ) The continuous fall in the production of minett ore is shown in the following table (1,000 tons of iron):

\begin{tabular}{crllc}
\hline Month & Production & & Month & Production \\
\cline { 1 - 2 } \cline { 5 - 5 } Average 1943 & & & & 728 \\
1944 Jan. & 935 & & May & 673 \\
Feb. & 908 & & June & 669 \\
March & 1026 & & August & - \\
April & 928 & & & \\
\hline
\end{tabular}

Source: Präsident Kehrl, Statistische Handakte, R3:1657B (B A).

${ }^{54}$ ) See below, p. 122. 
Britain as well as the Soviet Union, the transport of iron ore in Swedish ships was stopped in August of 1944. At the end of September German vessels were also prohibited from visiting the Swedish Baltic ports. The traffic via Narvik and the ports on the west coast of Sweden could not compensate for that loss, the less so as the state railways refused to re-direct goods trucks. Later that autumn deliveries via Narvik were stopped as well. ${ }^{55}$ )

Of what significance then were the simultaneous stoppages of the iron ore deliveries from France and Sweden for production conditions in the German steel industry? Judging by the analyses which were made during the autumn of 1944 the stoppages did not constitute a disaster or even a serious drawback. The storing of iron ore and scrap iron as well as pig-iron, which had increased sharply from the point of view of supplies during the good year of 1943, together with the production in the areas controlled by Germany, were regarded as being so extensive that the effect would hardly be noticeable until the spring of 1945 , and by that time-according to the administrators-German military successes ought to have made it possible for the deliveries to be resumed. ${ }^{56}$ )

${ }^{55}$ ) These various influences, which were accentuated by the unusually large exports in 1943, which shocked the allies, are clearly described in documents at the Swedish Foreign Office, the series HP64Ct, HP64Ba, HP64Ua and H40Ct (UD A), see below, p. 119. The Germans also connected the harsh Swedish attitude with pressure from the allies, e.g. the German envoy in Stockholm to Auswärtiges Amt 7/6 1944, R7X:46 (B A), Schnurre, to Auswärtiges Amt 23/8 1944, HaPol Schiffahrtsbez. Deutschlands zu Schweden, Band 5 (A A).

${ }^{56}$ ) The stock of iron ore in Germany is shown in table 30 below. In September 1944 the stock of scrap iron was 1.8 million tons, i.e. it was as high as during the spring of 1943 . The stock of pig-iron was kept to a constant 1 million tons during the whole of 1944. Statistische Handakte, Präsident Kehrl, R3:1657B (B A). In September 1944 Speer counted on a continuous production-even if reduced in comparison with 'Reich'-of Thomas steel for yet another 19 months. The stock amounted to almost 2 million tons (tons of iron). As far as the grades of low phosphorous ore for the production of Martin steel were concerned, the stock was almost as large, but the home production potential-apart from Erzberg in Austria-was lower. However the production of ingot steel could continue for a further $9 \frac{1}{2}$ months. Speer to Hitler 5/9 1944, R3:1525 (B A). In the Four Year Plan the same opinion was expressed. The blockade of the Baltic ports 'ist ... nicht mehr von so entscheidender Bedeutung und findet seine Auswirkung erst im nächsten Jahr nach Verbrauch der Bestände an phosphorarmen Eisenerzen'. Not until the middle of 1945 was the armament industry to be affected, with a cut of about $30 \%$. Beauftragter für den Vierjahresplan to Auswärtiges Amt 25/9 1944, Handakten von Behr (A A). 
The fact that the German steel works would not suffer any acute shortage of iron ore is confirmed by available sources. Unfortunately, however, there is no information later than January 1945:

Table 29. The German iron ore supply Oct. 1944-Jan. 1945

(1000 tons of iron)

\begin{tabular}{rcccc}
\hline Month & $\begin{array}{c}\text { Production } \\
\text { in 'Reich' }\end{array}$ & $\begin{array}{c}\text { Imports from } \\
\text { Sweden }\end{array}$ & Other imports & $\begin{array}{c}\text { The steel } \\
\text { works' stocks } \\
\text { at the end of } \\
\text { the month }\end{array}$ \\
\hline 1944 Oct. & 415 & 34 & 32 & 2681 \\
Nov. & 389 & 52 & 15 & 2371 \\
Dec. & 320 & 22 & 18 & 2204 \\
1945 Jan. & 300 & - & - & $\ldots$ \\
\hline
\end{tabular}

Source: Statistische Schnellberichte zur Kriegsproduktion, T84:195:1561122 (N A).

Thus the supply of iron ore to the German steel works was drastically reduced. However the German steel industry did not suffer a decline in production due only to the shortage of iron ore. Stocks were substantial and the systematic bombing raids on the German steel industry and the transport system caused a decline in production for other reasons. Instead the most important bottleneck-already more acute at the turn of the year 1944/1945-was the transport system which had been bombed to pieces; this caused above all a shortage of coal and coke, and as a result of that there was also a shortage of gas and electricity. ${ }^{57}$ ) Therefore the measures which the Swedes found it necessary to take would probably not have expedited the end of the war. ${ }^{58}$ )

${ }^{57}$ ) On the increased transport difficulties at the end of 1943, see Zentrale Planung 52:e Besprechung 21/12-43, FD, Handakten Milch, vol. 48 (IWM), Wagenfür, pp. 99,101 . As mentioned above the sources available for the last 6 months of the war are scanty. In the documents the transport difficulties are emphasised above all, e.g. Mitteldeutsche Stahlwerke to Herrn Reichswirtschaftsminister 7/3-45, T71:27:419283 (N A).

${ }^{58}$ ) It is symptomatic that at a discussion in the Reichswirtschaftsministerium on the 18 January 1945 transport problems, energy problems, fuel problems and labour problems were discussed, but not however the supply of iron ore. Reichswirtschaftsministerium, Versorgungs- und Produktionsprobleme, T:71:34:428592 ff. (N A). 


\section{F. Summary}

During the years immediately before the outbreak of the war the question of the German iron ore supply was to a high degree a political one. The shortage of iron ore which was feared by the Germans-and desired by the Allies-helped to shape foreign policies both before the outbreak of war and during the first war years.

The actual course of the war helped to provide Germany with a considerably strengthened base of raw materials for her steel production. Domestic production was maintained at quite a high level (production in 1943 was almost half as much again as the average in 1936/38), and Germany gained complete control over the French iron ore production and in addition an indirect but perfectly satisfactory control over the exports from Sweden. ${ }^{59}$ ) The positive development of the stocks of iron ore in Germany serves to illustrate this condition:

Table 30. Stocks of iron ore in Germany in 1938-1944

(million tons of iron)

\begin{tabular}{lllll}
\hline \multirow{2}{*}{ Point in time } & Quantity & & Point in time & Quantity \\
\cline { 1 - 2 } \cline { 4 - 5 } 4th quarter of 1938 & 2.5 & & $30 / 61942$ & 3.7 \\
$31 / 121939$ & 3.0 & & $31 / 121942$ & 4.6 \\
$30 / 61940$ & 1.6 & & $30 / 61943$ & 5.3 \\
$31 / 121940$ & 3.1 & & $31 / 121943$ & 5.7 \\
$30 / 61941$ & 3.0 & & Sept. 1944 & 3.0 \\
$31 / 121941$ & 4.8 & & $31 / 121944$ & 2.0 \\
\hline
\end{tabular}

Source: Statistisches Reichsamt, Monatliche Übersichten über die Rohstoffversorgung, T84:46:1325029 (N A), Statistische Handakte, Präsident Kehrl, R3:1657 B (B A).

Note 1 . The stocks of iron ore in Germany during the war years showed a very definite pattern, with a decrease in stocks during the spring and a reinforcement of stocks during the autumn. Apparently the shipments from Luleå ceased from December to May, which influenced the changes in stocks.

${ }^{59}$ ) On this see Chapter VI below. 
So from a general point of view the supply of iron ore during the war years did not constitute a political problem of resources..$^{60}$ ) It can also be established that the supply of iron ore did not form a bottleneck for the German steel industry for political reasons. ${ }^{61}$ )

${ }^{60}$ ) The special problems which beset parts of the German iron ore supply will be discussed in the following chapter.

$\left.{ }^{61}\right)$ The same interpretation is made by Jäger (1969) in the summary, pp. $301 \mathrm{ff}$. In a report for 1943 a certain amount of emphasis is placed on the good supply of phosphorous iron ore. For various reasons Swedish iron ore and minett ore had not been able to be used fully, and so domestic iron ore production had to be restricted and labour transferred to other sectors. Reichsvereinigung Eisen, Tätigkeitsbericht für das Jahr 1943, R10III:8 (B A). 


\section{III}

\section{THE TRANSPORTING OF IRON ORE BETWEEN SWEDEN AND GERMANY}

\section{A. Introduction}

As has been evident from the previous chapter, it is hardly possible to maintain that the German iron ore supply as a whole had to suffer any serious cuts during the war years because of political developments during the war. However, by way of introduction some reservations about the thesis's absolute validity, in connection with the previous chapter regarding the carriage of iron by sea, will be dealt with.

A certain proportion of the German imports of iron ore had in fact to be carried on waters which were unsafe for Germany. Thus because of inadequate military and political control carriage on these waters could result either in the ships being sunk or in the risks, and therefore the increased costs, becoming so great that shipments were reduced or were compelled to cease. From time to time this was the case with shipments from Spain and North Africa, and it also had an effect on the volume of shipping across the North Sea from Narvik. When in the autumn of 1943 the allies expressed their strong disapproval of the exceptionally high figures for the exports of iron ore to Germany during that year, the Swedish Foreign Office replied that an increase in the quantities exported in comparison with the previous year was due at least in part to the fact that the German collection of iron ore from Narvik had been able to continue moderately undisturbed by the operations of the allies. ${ }^{1}$ ) The exports via Narvik which were thus in-

$\left.{ }^{1}\right)$ UD to the Swedish Minister in London 3/9-43. H 40 Ct (UD A). 
fluenced by the policy of the Great Powers amounted to the following quantities:

Table 31. Sweden's iron ore exports to Germany via Narvik 1940-1944 (1000 tons of ore and as a percentage of Sweden's total exports of iron ore)

\begin{tabular}{cccccccc}
\hline Year & Quantity & $\%$ & & Year & Quantity & $\%$ \\
\cline { 6 - 7 } \cline { 5 - 7 } 1940 & - & - & & 1943 & 1944 & 19.2 \\
1941 & 730 & 7.6 & & 1944 & 1099 & 23.9 \\
1942 & 1140 & 13.3 & & & \\
\hline
\end{tabular}

Source: Sammandrag av Narviksleveranser (Summary of Narvik deliveries) (G A).

Note 1. 1940 refers to the period after April 9th.

The text which follows shows that the traffic on the Baltic was to be characterised by a gradual and perpetually increasing shortage of shipping. There were several reasons for this, and they will be discussed below. The German navy's allocation of German merchant vessels for various missions is suggested as a reason for the shortage of shipping, which was sometimes more prevalent. Thus it is possible to maintain that in this case also the traffic dwindled for 'political' reasons. However it has been considered appropriate to discuss this problem in the context of other shipping questions.

The purpose of the present chapter is in fact to examine whether shipping conditions in general had a restrictive effect on the German steel industry's supply of iron ore; in short, was the carriage of goods by sea a bottleneck for the German steel works? If the answer is positive, the reasons for it must be established.

Along with this-and almost as a result of work on the main problemcertain other problems will be discussed too. The carriage of iron ore made extremely heavy demands on shipping in relation to the value of the product, ${ }^{2}$ ) and shipments of iron ore constituted a very significant proportion of the total volume of shipping carrying goods between

$\left.{ }^{2}\right)$ The breakthrough of the Swedish exports of iron ore coincided with, and was a partial cause of, the expansion of the Swedish merchant navy around 1900. Fritz (1967), pp. $67 \mathrm{ff}$. The costs of sea transport 1903-1956 are shown by Meinander, folded diagram 4. 
Scandinavia and Germany during the war. ${ }^{3}$ ) An account of this will therefore inevitably shed light on fundamental aspects of merchant shipping during the war. ${ }^{4}$ )

\section{B. Shipping conditions during the latter half of the 1930s}

The information in the official statistics published by the Swedish authorities does not enable an estimate to be made either of the various shipping ports, or of the import ports or of the nationality of the ships carrying the Swedish exports of iron ore. The German documents only give sporadic and incomplete information on these matters. To answer questions about them it has been necessary to use materials from the export companies themselves. In this respect it is therefore highly advantageous that Swedish iron exports were concentrated in a single company, the Grängesbergsbolag, which in addition was responsible for the exports from several other smaller export mines. The Grängesbergsbolag disposed of its own and other mines' iron ore abroad in the following proportions, calculated as a percentage of Sweden's total exports of iron ore, so that the extent to which the sources used are representative-as an actual share of the total-will also be shown:

Table 32. The Grängesbergsbolag's exports of iron ore as a percentage of Sweden's total iron ore exports $1935-1944$

\begin{tabular}{|c|c|c|c|c|c|c|c|}
\hline Year & $\%$ & Year & $\%$ & Year & $\%$ & Year & $\%$ \\
\hline 1935 & 88 & 1938 & 91 & 1941 & 79 & 1944 & 77 \\
\hline 1936 & 90 & 1939 & 89 & 1942 & 77 & & \\
\hline 1937 & 92 & 1940 & 83 & 1943 & 82 & & \\
\hline
\end{tabular}

Source: Sammandrag av Narviks-, Luleå- och Oxelösundsleveranser (Summary of Narvik, Luleå and Oxelösund deliveries) (G A)

${ }^{3}$ ) Already during the pre-war period imports of iron ore constituted over $75 \%$ of the total quantity of German imports from Scandinavia. OKW WiRüAmt, Das skandinavische Verkehrsproblem, T84:89:1379760 (N A).

${ }^{4}$ ) Swedish shipping conditions during the second world war have not yet been the subject of scientific research. 
The shipping via the various export ports was characterised by a fairly stable pattern during the end of the 1930s. As has been pointed out above, Narvik was the most important export port, her comparative importance growing as the total exports of iron ore from Sweden increased. After Narvik, Luleå was the most significant export port, in spite of the short shipping season, followed by Oxelösund. Other export ports, such as Gävle, Hargshamn, Stockholm, Västerås and Otterbäcken, were of far less importance in this connection. Thus in the year $193755 \%$ of Sweden's exports of iron ore were shipped via Narvik, $22 \%$ via Luleå, $15 \%$ via Oxelösund, and $8 \%$ via other ports (a complete account for the whole period is given below, table 33).

The distribution between Narvik, Luleå and Oxelösund was a natural reflection of the volume of production at the country's three largest mines, Kiruna, Gällivare/Malmberget and Grängesberg, each of which for reasons of transport economy had its own natural export port. Certain smaller quantities of Gällivare ore were shipped via Narvik, and also certain Kiruna ore via Luleå. However these 'transposed' quantities never attained any greater dimensions during the 1930s.

A stable pattern also characterised the import ports for the iron ore from Sweden. Rotterdam was the dominant unloading port, followed by Emden. Both of these ports served as unloading ports for exports to the Ruhr area. Other important unloading ports were Antwerp, for Belgium's imports, and also Stettin, which received the ore which was used in the steel works in Upper Silesia and Czechoslovakia. Quite naturally the shipping from Luleå and Oxelösund was more strongly concentrated round the German Baltic ports than the vessels from Narvik were, all of which only frequented such ports as Stettin occasionally. Of the total exports of iron ore from Sweden to the continent of Europe in 1937 almost 52\% were unloaded in Rotterdam, 27\% in Emden, i.e. in combination almost $80 \%$, while Antwerp received $9 \%$ and the German Baltic ports $11 \%$, of which Stettin received two-thirds (see below, table 34).

During the latter half of the 1930s Swedish vessels were responsible for over $40 \%$ of the total of direct trade between Sweden and abroad. ${ }^{5}$ ) As regards the carriage of iron ore, the Swedish share was in fact smaller.

${ }^{5}$ ) The Swedish proportion was falling, from almost $46 \%$ in 1935 to just over $41 \%$ in 1938. Svensk Sjöfartstidning, 1941, p. 145. 
The reason for this is partly to be found in the conditions on the freight market.

The Swedish export ore-and this still means the Grängesbergsbolag's selling of its own and other mines' ores-was sold on an f.o.b. basis as well as c.i.f. The exports to Germany and Czechoslovakia, which constituted about $80 \%$ of Sweden's exports of iron ore, were sold f.o.b., which meant that the buyers had to be responsible for the carriage by sea, and had to enter into agreements with shipping companies. ${ }^{6}$ ) This resulted in German vessels acquiring about $40 \%$ of the freight, Dutch ships $15-20 \%$, and Norwegian ships about $5 \%$. The Swedish share fell from $47 \%$ in 1935 to barely $30 \%$ in 1938 , or 4 million tons a year. (See table 35).

\section{From the outbreak of the war to the start of the blockade of Skagerack}

From 1936, when it amounted to 3.6 million tons gross, the German merchant navy had expanded rapidly, and on 1 September 1939 it amounted to almost 4.5 million tons gross. ${ }^{7}$ ) Because of the allies' superiority at sea a large number of German ocean-going vessels were recalled during the period around the outbreak of the war. By virtue of the reduction of the ocean trade after the outbreak of war a good supply of German shipping was made available in the autumn of 1939, inter alia for the carriage of iron ore across the Baltic. Therefore at the end of September 1939 the shipping situation looked very promising. ${ }^{8}$ )

At the same time as Germany's supply of shipping increased in this way, Swedish vessels following the outbreak of war were burdened with sharply increased costs, above all for insurance against war risks and higher wages for the people employed on board. When the German vessels were not charged equivalent costs the Swedish shipping companies became much less competitive. ${ }^{9}$ )

These two factors contributed to a large reduction in the trade of the Swedish merchant navy, above all in the Baltic. Of the total direct

$\left.{ }^{6}\right)$ Meinander, pp. 228, 442. The Grängesbergsbolag's own shipping department had precedence in the transporting of ore to Germany.

${ }^{7}$ ) Steinweg, pp. $3 \mathrm{f}$.

${ }^{8}$ ) Ibid., pp. 5 ff. Svensk Sjöfartstidning, 1941, p. 491, OKW, WiRüAmt, Aktennotiz 3/6-40, T77:699:1911530. Entwurf 21/9-39, T77:699:1911731 (N A).

9) Svensk Sjöfartstidning 1940, p. 825, 1941, pp. 145, 492, Affärsvärlden 1940, p. 542. 
trade between Sweden and abroad, to which Swedish vessels contributed over $40 \%$ in 1935 , Sweden's share was reduced to $36 \%$ in 1939 and to $32 \%$ in the following year. Germany's share increased to a like extent and reached its peak in the early summer of $1940.0^{10}$ ) Likewise pronounced changes also took place in the carriage of ore, both as to the shipping and unloading ports and also as to the nationality of the vessels (see below).

\section{From the start of the blockade of Skagerack onwards: the formal framework}

When the blockade started on 9 April 1940 no immediate changes ensued for the shipping trade in the Baltic, whereas on the other hand shipping via Narvik ceased for the rest of 1940. However, the Swedish merchant navy was cut into two almost equal halves, which were to operate within two completely different fields for the rest of the war. Over 1 million tons dead weight ended up inside the blockade, of which 616,000 tons were coal-fired steamships. Owing to the unusually cold winter in 1940 several vessels remained in Sweden on 9 April, which made the confined fleet larger than was 'normal'. ${ }^{11}$ )

While the carriage of iron ore across the Baltic had continued during the autumn of 1939 and the spring of 1940 under the influence of an unconstrained market situation-leading to the result described abovein connection with a new trade agreement between Germany and Sweden in June 1940, the two countries also entered into an agreement over the shipping trade, which on the one hand laid down freight charges for the various types of goods, and on the other hand provided for the allocation of the quantities to be carried between vessels of various nationalities. ${ }^{12}$ )

$\left.{ }^{10}\right)$ Svensk Sjöfartstidning 1941, p. 145. In May 1940 German ships accounted for $72 \%$ of the total of direct shipments between Sweden and abroad, while the Swedish share was only $17 \%$. Eneborg (1940), pp. $141 \mathrm{f}$.

11) There was a total of 304 steamships which together amounted to 616,000 tons gross inside the blockade. Of these, 181 vessels (234,000 tons gross) were of less than 2,000 tons gross each. The motor vessels amounted to 373,000 tons gross, of which 193,000 was tanker tonnage. Statens Trafikkommission to Folkhushållningsdepartementet 31/10-40 (copy), HP 64 Ct (UD A). Ulff, p. 911.

${ }^{12}$ ) Niederschrift 13/6-40, HaPol, Schweden Handel 13A (A A). Cf. Hägglöf, pp. $138 \mathrm{f}$. The agreement meant a sharp fall in freight charges, Svensk Sjöfartstidning 1941, p. 65. 
With this, complete control of the shipping trade inside the blockade started, and continued in force, subject only to minor adjustments, for the rest of the war. As to freight rates, the principle was upheld whereby the shipping companies were to be compensated for the increases in costs which would occur, but not for reduced profits or reduced turnover. Thus the running costs of the shipping companies governed the freight rates It was of course of importance for the negotiators on behalf of the Swedish government-for reasons which will be explained elsewhere, p. 118-to push the freights down as much as possible in order to try and maintain a stable price level in Sweden. ${ }^{13}$ )

Therefore the German freighters-plainly with very bad grace-had to allow the Swedish shipping companies higher rates than the German equivalent. Even though satisfaction was expressed in Swedish negotiating circles over the fact that Swedish vessels inside the blockade had achieved secure employment at reasonable rates, the German concession must still have been based on Germany's need of iron ore and wood products. ${ }^{14}$ )

In the agreement in June 1940 it was laid down that Swedish vessels were to ship 200,000-225,000 tons of ore a month for the rest of the year. For the following years of the war agreements were made in connection with the yearly trade negotiations in the late autumn, which

13) Niederschrift 11/1 1941 with certain adjustments for higher insurance costs, Niederschrift 25/4 1941 mit Ergänzung 3-6/5 1941 with an addendum for lay-days and return freight in ballast, Niederschrift 8/7 1941 with some adjustments upwards for the German-Russian war, Niederschrift 16/12 1941, FIII:7 (SCB A), Vereinbarung 29/1 1943, Handelskommissionen, vol. 352 (R A), Vereinbarung 10/12 1943, Ha Pol, Schiffahrtsbeziehungen Deutschlands zu Schweden Band 5 (A A).

${ }^{14}$ ) As regards the cost structure of the shipping, the development of the freight market and the success of the shipping companies only a few general points will be made. Apart from the fact that the journeys took longer (convoys, detours, longer stoppages for loading and unloading) Swedish shipping inside the blockade-as mentioned above - was burdened with considerable increases in costs during the war. An estimate of these costs put the increases at about 2.25 times the level in the years before the outbreak of war. Fuel and insurance costs rose most sharply (about 4 times), while loading/unloading costs and ship taxes, which had previously been the major items of cost, only rose slightly. Eneborg (1942), pp. $176 \mathrm{ff}$. During the war freight charges for the transporting of iron ore must have increased 4 or 5 fold since 1939, while the average for traffic on Sweden remained at a 3-fold increase in freight charge;. Eneborg (1942), p. 356. On the dissatisfaction of the shippers, see Wenzel to Waldenström 12/9-40 (G A). 
provided that Swedish vessels were to transport 3.5 million tons of ore a year out of a total of about 10 million tons, i.e. about $35 \%$ of the total exports. This quantity was somewhat smaller than the total shipped in Swedish vessels in 1937, but was about twice as large as that carried in Swedish vessels on the Baltic that year. ${ }^{15}$ ) The following section will show the extent to which the formal decisions were to be realised, as well as the general influence of the war on the shipping trade.

\section{E. From the start of the blockade of Skagerack onwards: carriage of goods by sea as a bottleneck for the German iron ore supply}

\section{The Swedish shipping ports}

As previously mentioned in this research, Narvik's quays and loading equipment were destroyed in the battles in the late spring of 1940, and the shipping could not be resumed until January 1941, and then

Table 33. Iron ore shipping via Narvik, Luleå, Oxelösund and other Swedish ports 1935-1944

(\%)

\begin{tabular}{rrrcc}
\hline Year & Narvik & Luleå & Oxelösund & Other ports \\
\hline 1935 & 50 & 18 & 20 & 12 \\
1936 & 49 & 24 & 17 & 10 \\
1937 & 55 & 22 & 15 & 8 \\
1938 & 54 & 21 & 16 & 9 \\
1939 & 44 & 27 & 18 & 11 \\
1940 & 13 & 53 & 17 & 17 \\
1941 & 8 & 49 & 22 & 21 \\
1942 & 13 & 43 & 21 & 23 \\
1943 & 19 & 43 & 20 & 18 \\
1944 & 24 & 31 & 22 & 23 \\
\hline
\end{tabular}

Source: Sammandrag av Narviks-, Luleå- och Oxelösunds leveranser (Summary of Narvik, Luleå and Oxelösund deliveries) (G A).

Note 1. Under Narvik and Luleå are included ores from Kiruna and Gällivare together with Tuolluvaara and Koskullskulle, and under Oxelösund ores from Grängesberg and several smaller mines in central Sweden, e.g. Blötberget, Ställberg and Stripa. Thus 'other ports' is a balance item (cf. table 32).

15) See note 13 above. 
only with a greatly reduced capacity. ${ }^{16}$ ) The limits on the shipping from Narvik (see table 31 above) were partly due to the destruction of the loading equipment and partly to the superiority of the allies in the North Sea. ${ }^{17}$ ) Instead deliveries from Luleå were able to be extended considerably and they reached proportions undreamed of until then (cf. above, p. 43).

The great expansion of Luleå as a shipping port was of course followed by a strong concentration there of all the shipping in the months, normally May-November, when the port was accessible. Already in peace-time there was a clearly defined 'balance' between Luleå and Oxelösund in that shipping from Oxelösund was concentrated round the period when the port of Luleå was closed, i.e. the winter and spring months. This possibility of using the shipping to the full was exploited with advantage at least to the same extent during the war years. ${ }^{18}$ )

$\left.{ }^{16}\right)$ Meinander, pp. $270 \mathrm{ff}$.

${ }^{17}$ ) The largest monthly shipments from Narvik after 9/4 1940 amounted to 239,000 tons (May 1943), which can be compared with average monthly shipments in 1937 of somewhere near 650,000 tons. Sammandrag av Narviksleveranser (Summary of Narvik deliveries) (G A).

${ }^{18}$ ) The monthly shipments of Kiruna and Gällivare ore via Luleå, and Grängesberg's ore via Oxelösund from 1935 to 1943 are shown as percentages of the total yearly shipments in the following table:

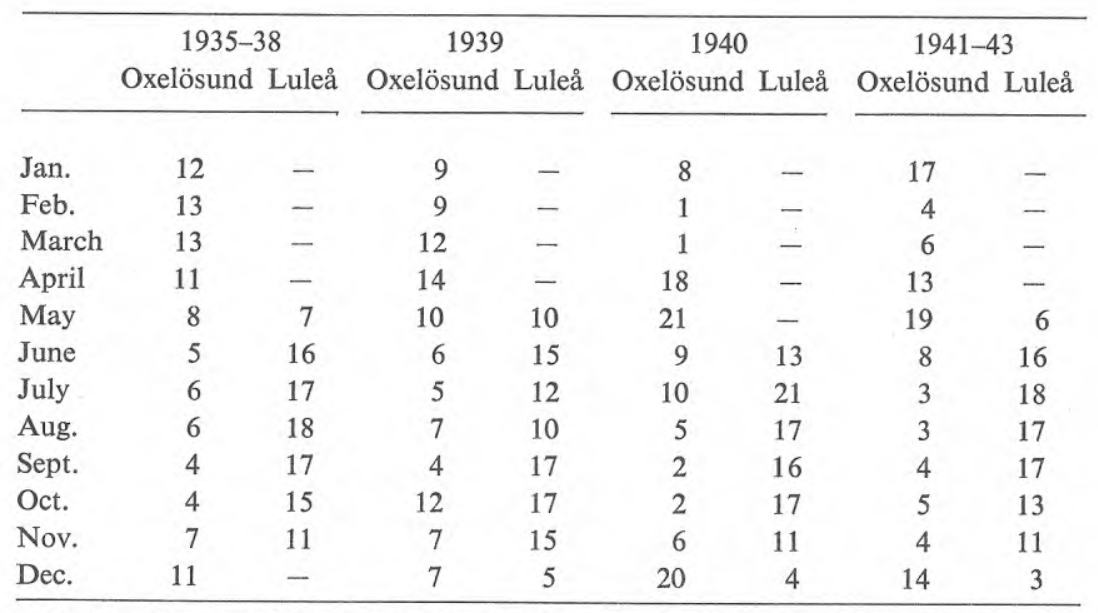

Source: Sammandrag av Luleå- och Oxelösundsleveranser (Summary of Luleå and Oxelösund deliveries) (G A). 
It has been pointed out by way of introduction that the three large export ports on the whole corresponded to the production of the three large export mines, i.e. Kiruna ore-Narvik, Gällivare ore-Luleå and Grängesberg ore-Oxelösund. With the sharp fall in Narvik shipping certain changes also took place in production at the Norbotten mines. In the period before the war the ratio of production as between Kiruna and Gällivare was about 75:25. During the war years a change to $70: 30$ occurred, which therefore meant that the Kiruna ore was still largely dominant but was being shipped via Luleå.

With regard to the whole of Sweden's shipping a general change also took place in the relation between exported Norrbotten ore and ore from central Sweden, whereby the latter increased its share. This change also has its cause in other circumstances which will be discussed below (p. 99).

Thus during the war certain important changes took place, in contrast to the stability of the pre-war years. It is clear that these changes, taken as a whole, meant a reduction in the volume of shipping. On the other hand there are grounds for pointing to the flexibility and adaptability which helped to maintain a high shipping capacity.

\section{The import ports on the Continent}

In the introductory statistical account of conditions in the 1930s emphasis was put on the great dominance of Rotterdam and Emden as unloading Table 34. Percentage of the total imports of Swedish iron ore via the more significant import ports on the Continent 1935-1944

\begin{tabular}{rrrrrrr}
\hline Year & Antwerp & Rotterdam & Emden & Bremen & Hamburg & $\begin{array}{c}\text { Baltic } \\
\text { ports }\end{array}$ \\
\hline 1935 & 7 & 49 & 36 & - & - & 8 \\
1936 & 7 & 51 & 34 & - & - & 9 \\
1937 & 9 & 52 & 27 & 1 & - & 11 \\
1938 & 9 & 52 & 26 & 1 & - & 11 \\
1939 & 5 & 40 & 28 & 9 & 8 & 10 \\
1940 & 1 & 2 & 28 & 29 & 22 & 19 \\
1941 & - & 31 & 21 & 16 & 12 & 19 \\
1942 & - & 24 & 20 & 20 & 16 & 21 \\
1943 & - & 7 & 27 & 26 & 21 & 19 \\
1944 & - & - & 20 & 32 & 24 & 24 \\
\hline
\end{tabular}

Source: See table 33.

Note 1. The figures are based on material from the Grängesbergsbolag (table 32 above). 
ports on the Continent (1937: $80 \%$ ). During the war the pattern changed radically. Rotterdam's importance as an unloading port declined greatly, above all in the years 1940 and 1943-1944, whereas on the other hand Emden's relative share remained fairly stable. Instead the loss of traffic in Rotterdam was replaced by a great increase in unloading in Hamburg and above all in Bremen, neither of which had previously been concerned in the importing of ore from Sweden. Together these two ports were to receive about one-third of the Swedish exports of iron ore.

The sharp decline in the importance of Rotterdam was not due to any great extent to the bombing raids on the town, but resulted from the great risks which attached to the shipping trade off the North Sea coast of Holland. Losses on this route were exceptionally high. ${ }^{19}$ ) Thus, in spite of the expense of transport from Bremen and Hamburg to the Ruhr, which was of course greater, it was in the common interest of Sweden and Germany to try and cut down the Rotterdam traffic. ${ }^{20}$ )

The war years not only brought a change from Rotterdam to the German North Sea ports but also a significant increase in the imports of the German Baltic ports, which rose from over $10 \%$ to about $20 \%$. It happened - though to a limited extent both in time and in volumethat Swedish iron ore, even ore which had been transported from Narvik, was unloaded in Stettin to be forwarded to the Ruhr. ${ }^{21}$ ) On the whole

${ }^{19}$ ) The Rotterdam traffic caused constant protests from the crews. Therefore shipping on that route had to be divided between the various Swedish shipping companies, who also complained that German ships only took part in this dangerous traffic to a much lesser extent. The German air-raid precautions were considered inadequate. However, the shipping companies were compensated with increased freight rates for freight to Rotterdam. Niederschrift 8/10-40, PM från Bränslekommissionen (Memoranda from the fuel commission) 30/6, 2/7 1942, 11/1 1943, BK 401, 402 (R A).

${ }^{20}$ ) However, from the point of view of the Swedish shipping companies it was a significant disadvantage that fairly large quantities of high quality Westphalian coke had to be collected from Rotterdam, preferably by Swedish ore shipping. In the Swedish fuel commission it was considered very important to keep up the transporting of ore to Rotterdam in order to be supplied with coke for the production of gas, and also for the industry's energy supply generally. Trafikkommissionens sammanträde 26/3-43, Protokoll from 'statsrådsberedningen' 4/3, 25/10 1943, BK 404, 405 (R A).

${ }^{21}$ ) In the months round the turn of the year 1940/41 over 100,000 tons of Swedish iron ore were unloaded in Baltic ports for transportation to steel works in the Ruhr. There were also similar arrangements during the autumn of 1943 and the summer of 1944. 
the increase in the unloading in the Baltic ports would in fact be a reflection of a comparative increase in the consumption of Swedish ore, above all in the works on the German coast and the steel works of Upper Silesia.

To sum up therefore, it can be established that the war brought about radical changes in the relative importance of the individual import ports. Apart from the aspect of cost, the change from traditional ore unloading ports (Rotterdam) to completely untried ports (Hamburg) must have caused a decrease in the quantities imported. However in this respect also there is every reason to lay stress on the flexibility.

\section{The composition of the shipping}

It has been mentioned above (p. 66) that according to the trade agreements from 1941 onwards Swedish shipping was to deal with the transporting of 3.5 million tons of iron ore out of a total quantity calculated at about 10 million tons. This figure was exceeded considerably, which is the more remarkable since after 9 April 1940 Swedish vessels no longer carried ore from Narvik but only took part in shipments across the Baltic. Carriage on board Swedish vessels amounted to about 5 million tons a year during the period 1941-1943, and therefore the share of the Swedish merchant navy amounted to at least half instead of the estimated $35 \%{ }^{22}$ ) On the other hand the share of the German merchant navy in 1941-1943 was reduced, above all in comparison with the years 1939-1940 but also in comparison with the pre-war years. This decline in German shipping, which was absolute as well as comparative, was caused by a real shortage of vessels, a problem which will be discussed below.

${ }^{22}$ ) Reichsvereinigung Eisen, Hauptabteilung Statistik: Skandinavische Verschiffungen an Erzen, Abbränden, Sinter und Briketts, sowie Phosphaten, R10III:106 (B A). In this connection it can also be mentioned that the Grängesbergsbolag's vessels, which before the outbreak of war were responsible for the greater part of the Swedish shipping and had contributed about $25 \%$ of the total ore shipping, almost completely disappeared as ore transporters during the war, and their share fell to about $5 \%$. Thus it was not the traditional ships which were used for the carriage of ore during the war. In place of the fairly large vessels which were specially constructed to carry ore, older and smaller ships were incorporated in the traffic. In the Baltic traffic the average cargo load per vessel fell from about 6,000 tons to approximately half during the war. Sammandrag av Luleå- och Oxelösundsleveranser (Summary of Luleå and Oxelösund deliveries) (G A). 
Table 35. The composition of the iron ore shipping 1935-1944

\begin{tabular}{cccccccc}
\hline \multicolumn{7}{c}{$\%$} \\
\hline Year & Swedish & German & Dutch & Norwegian & Finnish & Danish & Others \\
\hline 1935 & 47 & 36 & 11 & 5 & - & - & 1 \\
1936 & 35 & 39 & 18 & 6 & - & 1 & 1 \\
1937 & 30 & 40 & 17 & 7 & 2 & - & 4 \\
1938 & 30 & 42 & 16 & 6 & 2 & - & 5 \\
1939 & 19 & 58 & 14 & 4 & 1 & - & 4 \\
1940 & 23 & 62 & - & 1 & 5 & 1 & 7 \\
1941 & 47 & 33 & 2 & 1 & 9 & 7 & - \\
1942 & 46 & 34 & 3 & 2 & 7 & 7 & - \\
1943 & 40 & 33 & 1 & 2 & 12 & 11 & - \\
1944 & 36 & 44 & - & 3 & 7 & 11 & - \\
\hline
\end{tabular}

Source: See table 33.

Note 1 . See table 34 , note 1 .

2. Among other shipping English vessels for the years 1939-40 had figures of $3 \%$ and $7 \%$ respectively.

3. The figures in this table differ somewhat from those mentioned in German documents, which however comprise the total shipping of ore from Scandinavia. The German documents show the following distribution in 1941-1943:

Year Swedish German Dutch Norwegian Finnish Danish Others

\begin{tabular}{rrrrrrrr}
1941 & 51 & 30 & 2 & 2 & 9 & 7 & - \\
1942 & 54 & 31 & 2 & 2 & 5 & 6 & - \\
1943 & 48 & 30 & 1 & 2 & 9 & 10 & - \\
\hline
\end{tabular}

Source: Reichsvereinigung Eisen, Hauptabteilung Statistik, R10III:106 (B A).

The two series of figures may easily be reconciled on the basis of the assumption that the iron ore which was not sold by the Grängesbergsbolag was to a larger extent carried in Swedish ships.

\section{The shortage of shipping-a bottleneck for the iron ore supply?}

Whereas the reorganisation with regard to loading and unloading ports did not apparently create any greater problems-if it is possible to draw that conclusion on the basis of the sources' comparative silence on this point-it was instead the increasingly acute shortage of German 
shipping which led to the failure to collect the quantities provided for in the agreements. This may seem paradoxical against the background of an abundance of ships which existed during the whole of the first year of the war (above, p. 63). However the shortage was already beginning to make an impact during the autumn of $1940^{23}$ ) and of course it varied in degree. In general terms it can be said that the longer the war continued the more acute was the shortage. The question therefore is why was the shipping for German ore reduced to such an extent? There were many reasons for this.

The German merchant fleet was reduced in numbers throughout the war by substantial losses-although to a lesser extent on the Baltic itself. The following figures show the size of the German merchant fleet during the war:

Table 36. The German merchant fleet 1939-1944. Size and changes (1000 tons gross)

\begin{tabular}{lcccccc}
\hline Period & $\begin{array}{c}\text { Tonnage at } \\
\text { the start of } \\
\text { the period }\end{array}$ & Losses & $\begin{array}{c}\text { Losses } \\
\text { in the } \\
\text { Baltic }\end{array}$ & $\begin{array}{c}\text { Sales of } \\
\text { vessels }\end{array}$ & $\begin{array}{l}\text { Purchases } \\
\text { and newly } \\
\text { built ships }\end{array}$ & $\begin{array}{c}\text { Tonnage at } \\
\text { the end of } \\
\text { the period }\end{array}$ \\
\hline \multicolumn{1}{l}{ 1/9-39-31/12-40 4493} & 828 & 36 & 101 & 46 & 3610 \\
1941 & 3610 & 576 & 30 & 17 & 30 & 3046 \\
1942 & 3046 & 287 & 39 & 73 & 37 & 2723 \\
1943 & 2723 & 281 & 48 & 32 & 74 & 2485 \\
1944 & 2485 & 514 & 48 & - & 150 & 2122 \\
\hline
\end{tabular}

Source: Steinweg, pp. $29 \mathrm{ff}$.

Note 1 . In the work Deutschlands Rüstung im zweiten Weltkrieg the figures given for German losses are 898,000 tons gross up to and including $1940,335,000$ tons gross in 1941, 207,000 tons gross in 1942, 170,000 tons gross in 1943 and 349,000 tons gross in 1944 .

2. In a primary source the size of the German merchant fleet is stated to be $2,845,000$ tons gross on $1 / 61942$, K. Kaufmann's report 16/12 1942, FD 4195/45 (IWM).

\footnotetext{
${ }^{23}$ ) The German consulate in Luleå to Auswärtiges Amt 2/9 1940, Ha Pol, Schweden Eisenerz, Band 3 (A A).
} 
The sharp decrease in Germany's merchant shipping was thus due partly to losses at sea, but also to the new shipbuilding scheme which was on much too small a scale. The shipbuilding industry's incapacity for new production was due partly to shortage of labour and partly to the excessively limited share of steel for shipbuilding resulting from the general steel shortage. This vicious circle was heavily stressed by Karl Kaufmann, Reichscommissioner for German shipping, in a great number of written protests to Hitler and Martin Bormann, and it was also apparent, for example, to Speer. In addition far too few warships were built which might for example form convoys for the shipping of iron ore. ${ }^{24}$ )

At the same time as the German merchant fleet was being reduced it was also being given further tasks, in that Germany, because of her military conquests, had to maintain contact with countries which she occupied and supplies to her own troops in foreign countries. The traffic to and from Norway seems to have made particularly heavy demands on the shipping, as did the traffic in the Mediterranean. ${ }^{25}$ ) In addition - and more important - the German fleet decreased, since a large part of it was placed at the disposal of the German navy. The extent of this can be gauged only by occasional instances, but on these occasions it was very large. At the turn of the year 1941/42 no less than $60 \%$ were engaged by the navy and on 1 June 1942 only slightly less. Not only was a large proportion of the total tonnage involved: so also were the biggest and most modern vessels, which were required

\footnotetext{
${ }^{24}$ ) E.g. K. Kaufmann to M. Bormann $1 / 10-42,7 / 3-43$, K. Kaufmann's 6th-8th reports, FD 4195 (IWM). The problem of German shipping and shipbuilding was also discussed in Zentrale Planung, 8:e Besprechung betreffend Schwedenverkehr und Schiffsbau 26/6-42, FD, Handakten Milch, vol. 46 (IWM). The German navy also indicated that the excessively low ration of iron and steel for the building of warships was a reason for the superiority of the allies at sea which caused great loss of cargo ships, Dönitz's argument in Zentrale Planung's 40:e Besprechung 4/5-43, F D, Handakten Milch, vol. 47 (IWM). The vicious circle (no shipbuilding-no shipping of ore-no steel production-no shipbuilding) was also pointed out in Zentrale Planung 35:e Besprechung 2/3-43, F D, Handakten Milch, vol. 47 (IWM).

${ }^{25}$ ) These points of view are also vigorously put forward in Kaufmann's reports. Against the background of Germany's shortage of shipping her interest in transit traffic to and from Norway via Sweden is understandable.
} 
by the German navy, while those which went in civil traffic were smaller, old fashioned and clearly undermanned. ${ }^{26}$ )

Thus the German shipping which was at the disposal of civil traffic was considerably less than was stated in table 36 , above. Certain data can be given. On 1 June 1942 the 'free' shipping amounted to 947,000 tons gross, in the autumn of 1943 to $1,021,000$ tons gross and on 31 July 1944812,000 tons gross. ${ }^{27}$ )

Another reason for the shortage of shipping-although it varied in degree and it is hardly possible to quantify it - was of course the fact that the vessels had to sail in convoy or under escort by warships. This meant that the vessels' tour of duty was prolonged. ${ }^{28}$ )

In the civil traffic on the Baltic coal-fired steamships were used almost exclusively. The acute oil shortage in Germany prevented more substantial motor shipping. In addition there was a large reserve of Swedish motor shipping inside the blockade, most of which was laid up. In order to cure the shipping shortage the conversion of Danish motor vessels into steam vessels was also planned. ${ }^{29}$ )

However some rations of oil were distributed for the rapid transporting of ore. In $194115 \%$ of the ore imports were carried in motor ships. This proportion was gradually reduced and the last motor vessels were loaded with iron ore in January $1944 .{ }^{30}$ ) But on the other hand it is possible to maintain that from the transport point of view it was advantageous for the German iron ore supply that such a large proportion of coal-fired Swedish shipping was stationed in Sweden on 9/4 1940.

In the shipping agreements between Germany and Sweden it was implied that the vessels which carried ore were to have a return cargo of coal or coke. However this was not always the case. Instead it appears that vessels carrying ore from Sweden often returned in ballast. Likewise there were vessels which carried coal to Sweden and returned to Germany

\footnotetext{
${ }^{26}$ ) OKW, WiRüAmt, Tätigkeitsbericht 26/1-42, T77:367:1210470 (N A). Kaufmann's report 16/12-42, FD 4195 (IWM).

${ }^{27}$ ) Kaufmann's reports, FD 4195 (IWM).

$\left.{ }^{28}\right)$ Trafikaktiebolaget Grängesberg-Oxelösund, styrelseprotokoll 5/10-42 (G A).

$\left.{ }^{29}\right)$ Deutschlands Rüstung, p. 244.

30) 8:e and 9:e Besprechung der Zentrale Planung, Handakten Milch, vol. 46 (IWM), Reports from Sjöfartskommittén to UD, H 40 Ct (UD A), Svensk Sjöfartstidning 1941, p. 99.
} 
without any cargo of ore. Thus in spite of the prevailing shortage of shipping, the tonnage which was available was not rationally used. ${ }^{31}$ )

In Germany efforts were being made to compensate for the sharp decline in German merchant shipping by the most extensive use possible of vehicles from occupied countries. As is plain from table 35 above, the proportions of Norwegian and Danish shipping increased, as did the Finnish. ${ }^{32}$ ) The most important factor would have been the extentfar greater than the terms of the agreements prescribed-to which Swedish vessels could be assigned to the transporting of ore. From the date of the agreement on 13 June 1940 to the end of that year 800,000 more tons of ore than had been agreed on were carried on board Swedish vessels, and during the year 1941 about a million tons more. The substantial transport in Swedish vessels was also considered in Germany to be of great value. ${ }^{33}$ )

The situation was considered to be so serious that the German government planned a railway line from Narvik to the Oslo fjord for transporting Swedish Norrbotten ore. ${ }^{34}$ ) Thus the contribution from Swedish shipping meant above all that the quantities of exports to Germany could be fairly well maintained. The exports of iron ore from Sweden to Germany amounted to a total of about 35 million tons in 1940-1943 instead of the 40 million tons provided for in the agreement. Bearing in mind all the difficulties, the reorganisation of shipping-and of the import ports too, the reduced number of vessels, the shortage of German

$\left.{ }^{31}\right)$ This problem occurred from the start. Svensk Sjöfartstidning 1941, p. 458. Above all the Germans aimed at speedy ore deliveries with the return journey in ballast. The Swedish motor vessels, which received supplies of oil for transporting ore to Germany, always returned home in ballast. VPM from Trafikkommissionen 30/6-42, HP 39 H, Tyskland (UD A). Ballast in one direction of the voyage obviously meant increased costs, but as the shipping companies were compensated for this in the form of higher rates this could lead to a preference for going one way in ballast. Svensk Sjöfartstidning 1941, pp. 157, 457, Finanstidningen 1941, pp. 573, 612. From the German point of view also it was most profitable in a wider context that there should be coordinated shipping of ore and coal. Zentrale Planung 9:e Besprechung 15/7-42, F D, Handakten Milch, vol. 46 (IWM).

${ }^{32}$ ) The Danish vessels had apparently achieved the same conditions as the Swedish ships, Vereinbarung 31/8-41, Ha Pol, Schweden, Eisenerz, Band 3 (A A).

${ }^{33}$ ) Kaufmann's 9th report, F D 4195 (IWM), Wied to Auswärtiges Amt 20/10-42 Ha Pol, Schweden, Eisenerz, Bd 3 (A A).

$\left.{ }^{34}\right)$ Deutschlands Rüstung, p. 312. 
shipping, the shortage of oil for motor vessels and the poor coordination of the traffic, it can be established that transport by sea was well maintained during the war. The loss of almost 5 million tons of Swedish iron ore during the war could hardly constitute any serious bottleneck for the German steel industry. ${ }^{35}$ ) On the other hand it can reasonably be asserted that 5 million tons of high quality Swedish iron ore would have constituted a very valuable addition to Germany's iron ore supply, and the reasons for this will be given in the following chapter.

35) 5 million tons of Swedish iron ore correspond to about 3 million tons of iron. The total German (Reich) consumption 1940-43 amounted to about 70 million tons of iron (see above, p. 52). 


\section{THE IRON ORE SUPPLY FROM A SOCIO-ECONOMIC AND COMMERCIAL POINT OF VIEW}

\section{A. Introduction}

In earlier research on the importance of Swedish iron ore for Germany during the second world war only sporadic attempts have been made to integrate the iron ore supply with the other socio-economic and commercial economic realities which were current in Germany during those years. This situation is all the more remarkable since of course supplies of iron ore did not take place in isolation from other socioeconomic influences. ${ }^{1}$ ) To gain a more subtle appreciation of the German need for Swedish iron ore it is necessary to study the supply of various kinds of iron ore to the steel works from general economic and commercial economic aspects.

In making its choice between various kinds of ore for its pig-iron production a steel works has to resolve several different problems. In this context certain very special metallurgical aspects are disregarded, viz. the various chemical combinations of iron ores, which naturally affected their uses and prices. ${ }^{2}$ ) Instead attention will be focussed on the quality of the iron ore which was of the greatest significance for its price at the smelting-house works, viz. the actual iron content.

In an earlier chapter it has been shown how a steel-works based its pig-iron production on low iron-content domestic ores (with an iron content down in the region of $25 \%$ ) as well as on imported ores with

$\left.{ }^{1}\right)$ One exception is Jäger, (1969) pp. $72 \mathrm{ff}$., who discusses the higher cost of the German domestic ore generally but in isolation. Jäger's conclusions coincide with those reached in the present analysis, but he does not then integrate these results into his account of the German iron ore supply.

${ }^{2}$ ) In chapter $\mathrm{V}$ which follows the question of the phosphorous content of the iron ore is discussed. 
an extremely high iron content (with an iron content up in the region of $65 \%$ ). For reasons which will be discussed at length in the text below, the iron ores with a high iron content were in principle worth more than the types of ore with a low iron content (thus the remaining chemical constituents of iron ores, e.g. phosphorous content and manganese content, will be completely disregarded here). The price of the iron ore at the smelting-house works was determined above all by the mining and transport costs. So that the ore would be able to carry the costs of long transportation, e.g. across the Atlantic to Germany or from the very north of Sweden to Germany, it was vital that, thanks to its high iron content, it was of greater value to the buyer. In this regard the basic structure of the German iron ore supply is natural: domestic or near at hand ores (e.g. minett ore) with a low iron content on the one hand, and imported ores carried from a greater distance with a high iron content on the other. Schematically expressed it is possible to say that the German steel works had to make a choice between these two main types and that the difference in price was decisive.

The high price of the ore with the high iron content-still disregarding all aspects other than the iron content-was due to the fact that a larger quantity of pig-iron was obtained from a given quantity of this type of ore than was the case when ore with a low iron content was melted down. Therefore for the quantity of pig-iron produced less fuel (coke) ${ }^{3}$ ) was consumed, and a smaller number of workers had to be employed. In addition the smelting of iron ore with a high iron content required a smaller blast furnace capacity, or meant that the existing capacityeven in subsequent production lines-could be used in a more rational way.

Thus the schematic discussion above means that ore with a high iron content would have been specially sought after when coke prices were high or when for various reasons there was a shortage of coke, when wages were high or when there was a shortage of labour or in a situation in which the capacity of the blast furnaces was being used extensively. The same conditions naturally applied to scrap iron as the basic material

\footnotetext{
$\left.{ }^{3}\right)$ The saving in blast furnace coke by using Swedish iron ore instead of domestic ore in the Ruhr was estimated at half a ton for every ton of pig-iron produced. Zentrale Planung 8:e Besprechung 26/6-42, FD, Handakten Milch, vol. 46 (IWM). Jäger (1969), p. 76, puts the saving at $2-3 \%$ less coke consumed for each per cent increase of iron content in the ore.
} 
for steel production. ${ }^{4}$ ) Conversely the steel works' interest in ores with a lower iron content increased when the price of coke was low and when there was a good supply of coke, when the supply of labour was good and when there was a blast furnace capacity surplus. Thus the German demand for ore with a high iron content increased in the former case-especially if several or all of the factors mentioned occurred in combination-while the competitive strength of the minett ore and the domestic ores increased correspondingly in the latter case. ${ }^{5}$ )

It will therefore be of the greatest importance to find the answers to two questions. First, did the German steel works have a freedom of choice as regards the type of iron ore at the end of the 1930s and during the war years? With the boom period at the end of the 1930s it was indeed a seller's market, but during the war years there was in actual fact-as has been shown in previous chapters of this research-hardly any need for a shortage of iron in Germany. Even if, with expanding governmental control, the individual steel works did not have complete freedom of choice of iron ore, the German political leaders nevertheless conceded a theoretical right of choice between the two main types, ores with a low iron content (domestic and minett) and ores with a high iron content (imported ore from Sweden). ${ }^{6}$ ) Consequently the people responsible for the steel production had to take into consideration the other conditions in the commercial and industrial life of Germany.

$\left.{ }^{4}\right)$ It was emphasised that the scrap iron action was important precisely because increased supplies meant a decrease in the consumption of coke. Zentrale Planung, 18:e and 19:e Besprechung 28/10, 1942, FD, Handakten Milch, vol. 46 (IWM).

$\left.{ }^{5}\right)$ A substantial concentration of the domestic ore would of course have reduced the consumption of coke. Apparently the concentration of e.g. the Salzgitter ore was a technical problem and with the general shortage of steel during the war years steel could not be allocated to ore concentration plants in spite of the fact that people in responsible quarters were aware of its effect in saving coke. Niederschrift der Sitzung des Gutacht-Ausschusses über Rohstoff-Fragen am 26.5.36., R26I:29 (B A), Iron and Coal Trades Review, 1939, p. 411, Zentrale Planung 24:e Besprechung 5/11-42 (Ergebnisse), FD, Handakten Milch, vol. 46 (IWM), von Hanneken: Stand und Zukunft der deutschen Eisenwirtschaft, R13I:382 (B A).

$\left.{ }^{6}\right)$ The German negotiators of trade with Sweden tried to capitalise on this situation and laid heavy stress on the fact that Germany thanks to the minett ores at her disposition had less need of Swedish iron ore and therefore demanded a reduced price for Swedish iron ore. PM över sammanträde mellan de svenska och tyska regeringskommissionerna (Memorandum of meeting between the Swedish and German governmental commissions on) 20 November 1942, Hp 64 Ct, (UD A). 
The second question, which follows on from the first, is: what in fact was the situation in Germany before and during the war as regards coke prices and the supply of coke, wages and the supply of labour and also the supply of blast furnace capacity? Earlier, in a previous chapter of this research, reference has been made to certain facts which clearly indicate that Swedish iron ore became desirable in Germany. ${ }^{7}$ ) These factors will be discussed further in the text which follows.

\section{B. Questions of fuel, labour and capacity in German pig-iron production}

As regards the supply of coke to the steel industry for melting down iron ore it has been established earlier (p. 26) that from the end of the 1930s and throughout the war there was a marked shortage, in spite of the fact that the steel industry was given more and more priority in the distribution. ${ }^{8}$ ) When examination is made of the investigations which were carried out in Germany during this period and the discussions which took place between politicians, technicians and economists, there emerges a very clear consensus of opinion that the 'Engpass Kohle' was the fundamental reason for the inadequate production of the steel industry. ${ }^{9}$ ) The reasons for the inadequate supply of coke will not be the subject of any more profound inquiry in this context, ${ }^{10}$ ) but it seems to be perfectly clear that it is primarily a question of shortage of labour, especially skilled labour, and a badly functioning transport system. ${ }^{11}$ ) The actual shortage of coke, as well as the rise in the price

${ }^{7}$ ) See above, p. $17 \mathrm{ff}$.

${ }^{8}$ ) During one of Zentrale Planung's first meetings in the summer of 1942 Speer said: 'Es ist notwendig, eindeutig von der Zentralen Planung festzulegen, dass die dadurch im Inlande mehr zu Verfügung stehenden Kohlenmengen Zug um Zug der Eisenerzeugung zur Verfügung gestellt werden'. Zentrale Planung 9:e Besprechung 15/7-42, FD, Handakten Milch, vol. 46 (IWM).

$\left.{ }^{9}\right)$ It is symptomatic that the many discussions in Zentrale Planung about steel production and the allocation of steel to various sectors of German economic life were mainly concerned with the insufficient allocation of coal and coke.

${ }^{10}$ ) These conditions will be accounted for in a forthcoming analysis by SvenOlof Olsson, The Institute of Economic History, Gothenburg University.

11) 'Das Entscheidende ist der Arbeitseinsatz' (Pleiger the 'Coal Pope'). Zentrale Planung 16:e Besprechung 23/10-42, FD, Handakten Milch, vol. 46 (IWM). 
of coke, $\left.{ }^{12}\right)$ meant that blast furnaces had to be blown out and at times had to be left unused. ${ }^{13}$ ) The coal shortage also caused a shortage of gas which hampered subsequent production lines. From this aspect it was obviously a common concern both for the government and the steel sector that the imports of ores with a high iron content should be stimulated as much as possible, so that the production of steel could be increased with a reduction in the use of coke.

In this connection it is necessary to pause and contemplate the annual German exports of coal and coke to Sweden (about 3 million tons and 1 million tons respectively), which may seem paradoxical against the background of the situation on the German coal market. However the exports to Sweden, which came to a large extent from conquered areas of Poland, constituted a smaller burden on the German coal market, above all as regards blast furnace coke, since the use of Swedish iron ore by the steelworks meant large savings of this important product many times over. Actually the readiness of the Germans to deliver coal and coke indicates that Germany did not lose overall by the exchange. ${ }^{14}$ )

A comparatively high consumption of imported ores with a high iron content also had the advantage that mining at the domestic iron ore mines could be reduced-as in actual fact happened from 1941 onwards-and a large labour force which would otherwise have been engaged in iron ore mining could now be employed in coalmining or

${ }^{12}$ ) The development in the price of coal and coke will not be the subject of any special investigation here. However as an example of the sharp rise it may be mentioned that the price of coal-coke f.o.b. Emden was 11 Reichsmarks per ton in 1937 and 16.70 Reichsmarks per ton in the summer of 1942. Notiz über die Hochofenwerk Lübeck AG, T83:57:3426597 (N A).

${ }^{13}$ ) An example of the blowing out of the blast furnaces due to the shortage of coke, Reichsvereinigung Eisen: Bericht über das IV Quartal 1942, T71:34:428508 (N A), an example of the insufficient use of capacity due to the coke shortage, Hochofenwerk Lübeck AG, T83:57:3426600 (N A).

${ }^{14}$ ) Speer expressed his view on the exports of coal and coke to Sweden in the following way: 'So dass eigentlich über Kohle noch ein verhältnismässig gutes Geschäft gemacht wird. Die Kohle, die wir für die Schwedenerze hergeben, macht sich bei der Erzeugung des Eisens mehrfach bezahlt'. Zentrale Planung 8:e Besprechung 26/6-42, FD, Handakten Milch, vol. 46 (IWM). 
in other sectors of industrial life where there was a shortage of labour. ${ }^{15}$ ) Here we touch upon the second important bottleneck for the German steel industry, viz. the shortage of labour. This shortage occurred generally, but was accentuated as regards skilled workers and technicians of various kinds. The reason for this was not far to seek-the need of the armed forces for soldiers and specialists of various kinds-and substitutes in the form of prisoners of war or other imported labour could not fill the gap at all for many reasons. In spite of the fact that the steel industry as an important sector for the preparation of warfare was not affected by conscription to the same degree as many other sectors of German commercial and industrial life, the shortage did in fact cause fundamental disruptions in German steel production. ${ }^{16}$ ) To summarise the matter, it can be established that the situation on the German labour market was such that the interest in Swedish iron ore was further accentuated.

In this context only a brief reference will be made to a third bottleneck in German commercial and industrial life, which was of importance for Germany's attitude to Swedish iron ore. It concerns conditions of

$\left.{ }^{15}\right)$ When the mining of Dogger ore in Südbaden was no longer considered necessary the labour force could be transferred back to coalmining in the Saar, Deutschlands Rüstung, p. 76. Also, the exceptionally large exports of Swedish iron ore in 1943 meant that the mining in Germany could be slowed down and about 1,000 miners could be transferred to other tasks. Reichsvereinigung Eisen, Tätigkeitsbericht für das Jahr 1943, R10III:8 (B A).

$\left.{ }^{16}\right)$ The shortage of labour, above all of skilled labour, was put forward as being the narrowest of the bottlenecks in the production of steel after the shortage of coke, see e.g. Reichswirtschaftsministerium, Hauptring Eisenerzeugung, Tätigkeitsberichte, T71:34:428355 ff. (N A), Bezirkgruppe Nordwest der Wirtschaftsgruppe Eisen schaffende Industrie, Lagebericht, R10III:7 (B A), Reichsvereinigung Eisen, quarterly reports, T71:34:428508 ff. (N A), or Zentrale Planungs Besprechungen, FD, Handakten Milch, vol. 46-48 (IWM). Two examples may illustrate the favoured position occupied by the steel industry in spite of everything. From May 1939 to May 1941 total employment in Germany fell by almost $8 \%$, and within industry as a whole by $5.5 \%$, while employment within the steel and metal industry increased by almost $14 \%$. OKW, WiRüAmt, Ergebnisse der volkswirtschaftlichen Kräftebilanz vom 31 Mai 1941, T77:367:1210145 (N A). At the end of May 1939 the proportion of conscripts in the total number of males in the population in employment was $23.6 \%$, it was $21.4 \%$ of the workers in industry, and $17.3 \%$ of the steel and metal workers. OKW, WiRüAmt, Die beschäftigen Männer in der deutschen Industrie am 31.5.41. T77:367:1210153 (N A). 
transport by rail as well as canal. Steel production required great scope in transport. It was calculated that for each ton of rolled steel a total of 7 tons of raw materials and fuel had to be transported. In 1937 no less than $20 \%$ of German railway traffic was serving the steel industry. ${ }^{17}$ ) The German transport system functioned very badly for civil purposes, since the transporting of troops and war materials was given priority. It was therefore of considerable value that the German railway and canal networks were not also burdened with the carriage of domestic oreand of coal and coke-but that the supply of iron ore from Sweden to the steelworks was dealt with by Swedish goods trains and to a large extent by Swedish ships. It was pointed out in contemporary research that the actual exports of coal and coke to Sweden and the imports of iron ore from there made smaller demands on the scope of German transport than the carriage of domestic ore would do in the event of a suspension of Swedish iron ore deliveries. ${ }^{18}$ )

Finally, as regards blast furnace capacity it has already been mentioned that this was limited. ${ }^{19}$ ) In consequence there were reduced opportunities for the steel works to base their production of pig-iron on inferior grades of ore to any greater extent. The general steel shortage in Germany which has been accounted for earlier also hampered a larger expansion of blast furnace capacity or of concentration and briquetting works. Instead an increase in the use of imported ores with a high iron content meant that better use could be made of the existing blast furnace capacity, as well as that of the steel furnaces and rolling mills of course.

Thus if the German iron ore supply is considered in conjunction with the other economic realities which the German steel industry had to take into account in its choice of iron ore, primarily shortage of fuel, labour and blast furnace capacity, it appears absolutely plain that the Swedish ore with its high iron content would have been a priori highly desirable to the German consumers during the war years. However, the level of desirability was of course related to the development in price of the Swedish iron ore.

\footnotetext{
${ }^{17}$ ) Hauptring Eisen und Stahl, Rationalisierung in der Eisen schaffenden Industrie, R10III:7 (B A).

${ }^{18}$ ) Reichsvereinigung Eisen, Betr.: Auswirkungen eines evtl. Ausfalles skandinavischer Erze, 26/2-43, R10III:76 (B A).

${ }^{19}$ ) A certain shortage of capacity also existed in the Ruhr. Bericht des Herrn Bergassessor a.D. Dr. H. Winkhaus zur Frage des Erz- und Schrottpreisausgleiches, R13I:385 (B A).
} 


\section{The price relationship between domestic and Swedish iron ore}

It has not been possible to base any illustration of the price relationship between the various types of iron ore on documents of account from the individual producers of pig-iron. Even if such documents had been available it would have been difficult to study them since the steel works were compensated at least in part by the state for raised iron ore, coke and transport costs. ${ }^{20}$ )

As regards the development in the price of Swedish iron ore during the war, there were only minor adjustments upwards (mainly relating to the low phosphorous grades) of the Swedish f.o.b. price. In 1942 the f.o.b. price of the high phosphorous grades was about $10 \%$ above the pre-war level, and that of the low phosphorous grades was about $25 \%$ higher. ${ }^{21}$ ) The price of iron ore was linked on a price scale to that of the Swedish imports of coal from Germany, and therefore it became just as much in the Swedish as in the German interest to keep the price of

${ }^{20}$ ) In a proclamation in the spring of 1941 it was resolved that the steel works themselves would pay for the increase in the price of Swedish iron ore, while compensation for the increase in the costs of its sea freight would be paid at the rate of 2 Reichsmarks per ton. Payment of compensation for other iron ores would be at the rate of 4 Reichsmarks per ton. Beauftragter für den Vierjahresplan to Wirtschaftsgruppe Eisen schaffende Industrie 18/4-41, T71:85:588751 (N A). Hochofenwerk Lübeck showed the following rises in price for the period 1/9 1939-31/3 1942 and the compensation received for these.

\begin{tabular}{lccc}
\hline & $\begin{array}{c}\text { Increase in costs } \\
\text { (million Reichsmarks) }\end{array}$ & $\begin{array}{c}\text { Compensation } \\
\text { (million Reichsmarks) }\end{array}$ \\
\hline Ore freights & 2.5 & 2.3 (from Eisenkasse) \\
Ore prices & 1.0 & $1.0 \% ", "$ " and \\
Coal freights & 3.5 & $2.0 \%$ Kohlenkasse) \\
Coal prices & 1.9 & - & \\
\hline \multicolumn{1}{c}{ Total: } & 8.9 & 5.3 \\
\hline
\end{tabular}

The difference, 3.6 million Reichsmarks, was charged to the company itself. Notiz über die Hochofenwerk Lübeck AG, T83:57:3426594 ff. (N A).

On the other hand the cost of scrap-iron did not increase very much in 1937-1944. Statistisches Handbuch von Deutschland 1928-1944, p. 466.

$\left.{ }^{21}\right)$ Reichswirtschaftsministerium, Bezirkgruppe Nordwest der Wirtschaftsgruppe Eisen schaffende Industrie, Mehrpreis für Skandinavienerze, T71:85:588601 ff. (N A). 
iron ore at a stable level, even if the Swedish iron ore export companies thought that the price increases were too insignificant in regard to the large rises in costs which weighed heavily on the companies, especially during the first years of the war. ${ }^{22}$ )

But although the f.o.b. price was thus fairly stable, a considerable rise occurred in the iron ore price at the German steel works, mainly because of the increased costs of carriage by sea. This price increase is difficult to estimate, as the rise in costs consisted inter alia of compensation and subsidies of various kinds. It seems reasonable to assume that there was a quadrupling of the costs of transport to German or Dutch North Sea ports and a re-doubling of those to the Baltic ports compared to the pre-war period. ${ }^{23}$ ) This increase in the cost of freight would have meant almost a re-doubling of the price of Swedish iron ore at the German steel works. ${ }^{24}$ )

But as the price of iron ore rose in this way, the price of scrap iron was fairly stable. Therefore scrap iron became comparatively cheaper as a basic material for steel production. Apart from all the other advantages described above, scrap iron thus became especially desirable even from the point of view of price. Together these factors account for the great interest which the Germans plainly showed in an increased supply of scrap iron..$^{25}$ )

In spite of the very substantial rise in the price of Swedish iron ore as shown above, the ore was still extremely desirable in Germany from the point of view of price during the second world war. The price development and the situation of shortages on the German coke, labour

${ }^{22}$ ) The key role of coal and coke for the general price development in Sweden was often stressed, e.g. Statens Bränslekommission and many others to Statsrådet och Chefen för Kungl. Handelsdepartementet, Nov. 1941, Handelskommissionens prot. 1941 (RA). The Grängesbergsbolag's dissatisfaction with the low prices affected otherwise good relations with the Swedish government. Trafikaktiebolaget Grängesberg-Oxelösund styrelseprotokoll 12/2, 19/12 1940, 21/12 1942 (G A).

${ }^{23}$ ) See the chapter on sea transport, p. 65 note 14. Compensation for the increased costs of Swedish iron ore was paid to the companies from 1/7 1940 at the rate of 10 Reichsmarks per ton of steel. Beauftragter für den Vierjahresplan, Reichskommissar für die Preisbildung 5/6-40, R26II:27 (B A).

${ }^{24}$ ) According to certain information the price of Kiruna D-ore $(60 \% \mathrm{Fe}, 1.8 \% \mathrm{P})$ rose c.i.f. the Ruhr from 15.70 Reichsmarks in 1937/39 to 25.90 Reichsmarks in 1940/42. Statistisches Handbuch von Deutschland 1928-1944, p. 466.

${ }^{25}$ ) Statistisches Handbuch von Deutschland 1928-1944, p. 466, Milward (1970), p. 227. 
and transport markets were reasons for this, and from a commercial point of view Swedish ore was of great interest to governments and businessmen alike. ${ }^{26}$ )

Is it possible then to estimate the 'profit' made in German commercial and industrial life by the wide use of Swedish iron ore? A contemporary analysis-biased, certainly, but well-informed-of a possible increase in the consumption of domestic ore enables a more exact estimate to be made of the situation during the war years.

In the big effort which was being made at the end of the 1930s to increase the use of domestic German iron ores, the aspects of cost and profitability had, as has already been pointed out (p. 31) been pushed into the background in favour of political, military and propaganda arguments. The iron ore in Salzgitter had a very unfavourable chemical composition, and therefore required extra preparation. The mining, roasting and sintering of this ore involved great expense. It was already perfectly clear at this time how difficult to work and unremunerative these grades of iron were, but the politicians had their own way. ${ }^{27}$ ) Because of the shortage of coke and labour described above the cost of producing pig-iron on the basis of Salzgitter and Dogger ores rocketed, and pig-iron could be bought more cheaply from outside. This rise in costs, which caused growing irritation in the steel works, was acknowledged by the politicians responsible, but they maintained that the mining of domestic ores with a low iron content was necessary because of the emergency and was also desirable because it was estimated that the demand for steel in Europe after the war would reach such proportions that the German steel industry would not be able to base its production entirely on imported ores. There were plainly substantial questions of prestige involved in the attitude of the politicians and those

\footnotetext{
${ }^{26}$ ) Niederschrift über die am 18. Dezember 1940 im Reichswirtschaftsministerium abgehaltene Besprechung betr. Eisenerzpreisausgleich, R13I:382 (B A).

${ }^{27}$ ) See e.g. Niederschrift der Sitzung des Gutachtausschusses über RohstoffFragen 26/5-36, R26I:29 (B A), with a discussion between Göring on one side and the technicians and economists on the other. In a later and different context (in conversations with the head of the Grängesbergsbolag, Waldenström, in 1937) Göring in fact explained that Germany preferred Swedish iron ore from the point of view of cost among other things. At this meeting Göring also expressed a wish for a 10 year contract with Sweden for the delivery of ore, Trafikaktiebolaget Grängesberg-Oxelösund styrelseprotokoll 7/4-37 (G A).
} 
responsible for the Reichswerke Hermann Göring in their decision to continue the mining of domestic iron ore. ${ }^{28}$ )

In fact the difference in price between the comparatively expensive domestic iron ore and the imported ore became of such importance that steel works which based their production of pig-iron mainly on domestic iron ores had to be compensated by other companies which used imported iron ores to a large extent. ${ }^{29}$ ) As a paradox it may be mentioned that Göring's creation, the state-owned Reichswerke Hermann Göring in Watenstedt, which was to produce steel from Salzgitter ore with a low iron content, expressed a wish to import iron ore from Sweden to reduce its consumption of coke which was above normal. ${ }^{30}$ ) The privately owned steel works were not opposed to this idea, since there would then be a reduction in the cost of compensation paid by them. ${ }^{31}$ ) From the summer of 1940 onwards there was a possibility of getting compensation for the steel works which based their production on domestic iron ore in a takeover of the steel works in Lorraine which had considerably lower production costs. In December 1940 the Reichswerke Hermann Göring gained control over the large de Wendel works. ${ }^{32}$ )

In fact the steel works were opposed in principle to compensation brought about by large differentials in costs. It was thought that the politicians exaggerated the need for domestic iron ore, and the un-

$\left.{ }^{28}\right)$ Niederschrift über die am 18. Dezember 1940 im Reichswirtschaftsministerium abgehaltene Besprechung betr. Eisenerzpreisausgleich, von Hanneken, Stand und Zukunft der deutschen Eisenwirtschaft, R13I:382 (B A). Cf. Petzina pp. $102 \mathrm{ff}$. Industria, 1939, p. 392, U.S. Strategic Bombing Survey, p. 101.

${ }^{29}$ ) Ibid., von Hanneken to Poensgen 18/11-40, R13I:382 (B A).

${ }^{30}$ ) On learning of the fact that Hermann Göring had decided to use Swedish iron ore in the Reichswerke Hermann Göring in Watenstedt the spokesman for the private sector of the steel industry, director Poensgen, was called upon to say that Thyssen on one occasion had bet Pleiger, head of Reichswerke Hermann Göring, a number of bottles of Sekt that the Reichswerke would at one stage have to use Swedish iron ore for its production of pig-iron. Then Vögler from Vereinigte Stahlwerke had been of the opinion that it was simply not possible just to wager a couple of bottles of Sekt on such an important question and the bet was raised to 10,000 Reichsmarks. Niederschrift über die am 18. Dezember 1940 im Reichswirtschaftsministerium abgehaltene Besprechung betr. Eisenerzpreisausgleich, R13I:382 (B A). On Thyssen's attitude towards the Reichswerke Hermann Göring see Chapter II, note 8.

${ }^{31}$ ) Aus der Besprechung mit Herrn General von Hanneken am 10.12.40. im Reichswirtschaftsministerium, R13I:382 (B A).

${ }^{32}$ ) Milward (1970), pp. $226 \mathrm{f}$. 
economic and irrational consequences of such a high consumption were put forward. Certain representatives of the private steel industry considered that the mining of domestic ore was unnecessary but realised that the steel industry had to use it for political reasons. ${ }^{33}$ ) Naturally there entered into the prolongation of this discussion the steel industry's fear of controls of coke and freight costs and of an increase in government influence generally, which had begun with the foundation of the Reichswerke Hermann Göring and would perhaps end in the socialisation of the whole sector. ${ }^{34}$ )

How great was the difference in price between the imported iron ore and the domestic? In this context it is normal to calculate on the basis of the cost per ton of pig-iron produced, as the use of the poorer iron ore always meant an increase in the costs of blast furnace coke and labour. It is hardly necessary to point out that all calculations of this kind are tentative.

According to one well-informed analysis the average cost of producing one ton of Thomas pig-iron at four steel works in the Ruhr using imported ore as the raw material amounted to just over 42 Reichsmarks-plus an estimated capital profit and taxes of about 4 Reichsmarks. The cost of producing one ton of pig-iron in the Ruhr using exclusively domestic iron ore was estimated at almost 97 Reichsmarks. In the latter case the cost of production was in fact twice as high. ${ }^{35}$ ) Corresponding

${ }^{33}$ ) Wenzel from Vereinigte Stahlwerke explained on one occasion: '. . . es würde den schärfsten Wiederspruch der allerhöchsten Stellen herbeiführen, wenn wir erklären wollen: "Wir haben es nicht nötig", obwohl es wirtschaftlich für uns das allerangenehmste wäre'. Niederschrift 28/7-41, R13I:385 (B A). By and by however there was a decline in the use of the Salzgitter ore by the Ruhr works. Hermann Göring-Werke, FD 3175/45 (IWM).

${ }^{34}$ ) Niederschrift über eine am 11. Dezember 1940 mit Herrn Kommerzienrat Dr Hermann Röchling geführte Besprechung, R13I:382 (B A). Niederschrift über die am 18. Dezember 1940 im Reichswirtschaftsministerium abgehaltene Besprechung betr. Eisenerzpreisausgleich, R13I:382 (B A), Niederschrift über die am 28. Juli 1941 abgehaltene Sitzung betr. Erz- und Schrottpreisausgleich, R13I:385 (B A). See also the interpretation of the relationship between politicians and representatives of the steel industry in Eichholtz, pp. $51 \mathrm{f}$.

${ }^{35}$ ) Bericht des Herrn Bergassessor a.D. Direktor Dr. H. Winkhaus zur Frage des Erz- und Schrottpreisausgleiches, R13I:385 (B A). The cost of 46 Reichsmarks relates to the year $1935 / 36$ and since then the price of iron ore had risen. On the other hand pig-iron produced from domestic iron ores had to bear other costs in the subsequent production process which were not included in the sum of 97 Reichsmarks which was given. According to the investigator these extra costs cancelled each other out. 
production in the neighbourhood of the domestic iron ore mines e.g. at the Reichswerke Hermann Göring, was apparently not as costly as in the Ruhr, but a more precise estimate of this is not possible. ${ }^{36}$ )

Thus by way of summary a rough estimate would indicate that the production of pig-iron in Germany during the war years based on domestic iron ores would be twice as expensive as that based on Swedish iron ores. It was apparently also less expensive to produce pig-iron using Swedish iron ores as the basic material than to use the minett ores, in spite of the fact that-at least in the winter of 1941-considerably less was paid for the minett ore than before the war. ${ }^{37}$ ) If the general assumption is made that in 1942 in Germany ('Altreich') 4.5 million tons of pig-iron were produced with Swedish iron ore as the basic material, and that this production meant a saving of 40 Reichsmarks per ton of finished pig-iron in comparison with the cost of using domestic iron ore, this would mean a total German socio-economic saving of about 180 million Reichsmarks in that year, which can be compared with the f.o.b. value of the total exports of Swedish iron ore to Germany in the same year, viz. 90 million Reichsmarks.

However the arithmetical example is in a sense hypothetical. In order to maintain production of pig-iron unchanged in the event of a possible loss of the deliveries of Swedish iron ore a great increase in the mining of iron ore in Germany would have been required, yielding approximately a further 19 million tons (the production in 'Altreich' in 1943 was 15 million tons). ${ }^{38}$ ) In addition other demands were to be made both on

${ }^{36}$ ) Not even the best informed people were able to make adequate comparisons of costs between the Reichswerke Hermann Göring and the rest of the steel industry. Reichsvereinigung Eisen to Speer 28/1-43 R10III:53 (B A). See also a very dubious calculation in Jäger (1969), p. 75. Klein's estimate that the cost of pig-iron produced from domestic iron ores was $10 \%$ higher than the cost of pig-iron produced from Swedish iron ore is clearly too low. Klein, p. 42.

$\left.{ }^{37}\right)$ Bemerkungen zu dem Schreiben des Herrn von Hanneken vom 18.11.40., R13I:382 (B A). While the price of minett ore had been about 5 Reichsmarks per ton before the war, in January 1941 the price paid was between 3.50 and 4.50 Reichsmarks per ton. From 1942 onwards the price was increased to 4.50 Reichsmarks per ton. Note 7/1-41, Deutsche Waffenstillstands-Delegation to Auswärtiges Amt 16/6-42, HaPol Frankreich, Eisenerz (A A), Der Militärbefehlhaber in Frankreich to Oberberghauptmann Gabel 6/5-42, T71:21:412166 (N A).

${ }^{38}$ ) Reichsvereinigung Eisen, Ausfall skandinavischer Erze, 1/3-43, R10III:78 (B A). 
coal mining and on the transport potential. Apart from the enormous cost of investment in the mines, ore concentration plants, the transport system, blast furnaces etc. and greatly increased running costs, such a re-structuring of the iron ore supply would of course fall heavily on other sectors of German economic life.

Set in such a context the supply of iron ore to the German steel works obviously becomes a latent but threatening bottleneck, nothing like as obvious as the shortage of coke, for example, but just as important in a wider perspective. From this point of view the Swedish iron ore deliveries were plainly of very great importance to the German war economy. 


\section{V \\ IRON ORE QUALITY AND THE IRON ORE SUPPLY}

\section{A. Introduction}

In the preceding analysis of the German iron ore supply during the latter part of the 1930s and during the second world war no qualities of the iron ore apart from its actual iron content were considered. In this respect the present account is similar to earlier works dealing with problems connected with this question..$^{1}$ ) In this, however, an extremely important facet of the issue is lost in the combination of problems to which the German iron ore supply gives rise. It concerns the varying content of phosphorus in the iron ore and its consequences for the continuing production of steel.

In fact the phosphorus content of the iron ore played a decisive role at this time for the subsequent processing of the steel and for its various uses. From iron ore with a high phosphorus content, e.g. the major part of the Swedish iron ore, which contained $1-2 \%$ phosphorus, Thomas steel was produced which was in turn made into ship plates, railway tracks, builders' hardware, etc. On the other hand, for the production of certain high quality steel products, e.g. for machinery and for use in armaments, iron ore with a low phosphorus content or scrap iron were required as raw materials. ${ }^{2}$ ) The iron ores containing the least phosphorus went into the production of acid Martin, Bessemer or electric steel, while iron ores with a somewhat higher phosphorus content $-0.1 \%$ at the most-were being used as raw material for the

$\left.{ }^{1}\right)$ Although this issue is touched on by Jäger (1969), pp. 134, $184 \mathrm{f}$., he does not however integrate this issue into the bigger problem with which he deals, viz. the German steel industry's need of foreign iron ore.

${ }^{2}$ ) On the other hand a high phosphorus content in the iron ore was desirable for the manufacture of certain other products. Gemeinfassliche Darstellung des Eisenhüttenwesens, p. 16. 
production of basic Martin steel. This latter steel did not have the qualities which the steels mentioned above possessed but it was in fact superior to the ordinary Thomas steel and it was therefore used within the armaments industry. ${ }^{3}$ ) Thus the dividing line between the low phosphorus and the high phosphorus iron ores was drawn at $0.1 \%{ }^{4}$ ) Of the total German supply approximately $20-25 \%$ came below that line..$\left.^{5}\right)$

With the accelerated rearmament from the end of the 1930s it is possible then to assume that there was a strongly increased demand in Germany for Martin steel and consequently for low phosphorus iron ore as well as scrap iron. How could this expanding demand be satisfied?

\section{B. Germany's supply of raw materials for the production of high quality steel}

\section{Introduction}

The domestic iron ores almost without exception had a high phosphorus content. Only in Siegerland in western Germany were smaller quantities of low phosphorus iron ore mined. For this reason alone all the talk towards the end of the 1930s about a German armament industry based on domestic iron ore was divorced from reality. Therefore the country's supply of iron ores which were poor in phosphorus had to come mainly from imports from abroad at this time. Of Germany's imports of these grades Spain accounted for about 500,000 tons (tons of iron) and North Africa for 300,000-500,000 tons. About 600,000 tons were imported each year from Norway and about 900,000 tons from Sweden. ${ }^{\text {) }}$ In all this meant, e.g. in 1938 an import of about 2.5 million

${ }^{3}$ ) The basic Martin steel had a phosphorous content of $0.02-0.05 \%$, the Thomas steel $0.04-0.08 \%$, ibid., pp. 97, 107.

4) Reichsstelle für Eisen und Stahl, Eisenbilanz 2/10-39, R10III:1 (B A).

5) See table 37 below, Reichsvereinigung Eisen, Erzbilanz 1943, R10III:1 (B A).

$\left.{ }^{6}\right)$ See table 13, p. 34 . The volume of the imports of iron ores with a low phosphophorus content from Sweden is not shown in any official trade statistics. The information is based on a German collocation, Schwedenerz-Ausfuhr nach Deutschland 1929-1943, 4/7-44, R7X:46 (B A). Milward (1970), p. 213, states that the iron ores in Normandy and Anjou were of great importance because of their low phosphorus content. However, in the German documents these iron ores are classified as high phosphorus, e.g. Reichsvereinigung Eisen, Erzbilanz 1943, R101II:79 (B A). 
tons (tons of iron), while Germany's supply of scrap iron amounted to 3.5 million tons, of which 1.1 million tons were imported. ${ }^{7}$ ) Thus of Germany's total supply of raw materials for the production of steel that year, about one third can be classified as low phosphorus iron ores.

However the importation of low phosphorus iron ores during the latter part of the 1930s was not free from problems. At the same time as the demand for this type of iron ore was accentuated, deliveries from what was traditionally the most important delivering country, Spain, were reduced for natural reasons. In order to compensate for the reduced deliveries from Spain Germany took a greater interest in the iron ore deposits in North Africa. However the allies' superiority at sea caused the newly established connections to be cut off at the outbreak of the war, at a time when Spain, partly for the same reason, was unable to increase her deliveries to Germany.

With the conquest of Austria and access to her low phosphorus iron ore deposits the Germans assumed that substantial assistance in the supply of these grades would be forthcoming. However, in spite of the fact that great efforts were being made, the Austrian production never exceeded 900,000 tons (tons of iron) per year. Next to this, therefore, the low phosphorus iron ores from Norway and Sweden became the most important ores during the war years.

The loss of important import markets and a severely reduced import of scrap iron meant that the shortage of these kinds of material became acute already at the start of the war. ${ }^{8}$ ) While the supply of grades of iron ore with a high phosphorus content was mainly a problem of cost and transport, as is evident from previous chapters, the supply of low phosphorus iron ores and scrap iron then formed a real bottleneck in the production of certain grades in the German steel industry. The shortage in supply of materials of these kinds in fact varied in degree during the war years but never ceased to be an acute problem.

In what way then did the Germans try to deal with this 'ausgesproche-

\footnotetext{
${ }^{7}$ ) See above, p. 25.

$\left.{ }^{8}\right)$ Reichsvereinigung Eisen, Eisenwirtschaft seit Kriegsausbruch, pp. 21, 37, 39, 51, R10III:6 (B A).
} 
nen Materialmangel'?') Three solutions seem to have been nearest to hand. First, there was a suggestion of trying to extend the possible uses for the Thomas steel which was produced from the grades of iron ore which had a high phosphorus content. Secondly, attempts were made in various ways to increase the supply of scrap iron to the steel works, and thirdly, efforts were made to stimulate the imports of low phosphorus iron ores.

\section{The adaptability of Thomas steel}

A measure close at hand for the prevention of a situation in which there was a shortage of low phosphorus materials was of course the practice of stringent economy with these materials. There was a possibility of economising by trying to extend the serviceability of Thomas steel and above all by restricting the steel works' use of Martin steel for purposes where it was possible to use Thomas steel instead. This applied particularly to the production of ammunition which swallowed up steel, where Thomas steel was used more and more. ${ }^{10}$ ) Through certain technical innovations within the field of steel production during the war, there was a reduction in the content of dangerous materials, including phosphorus, in some of the Thomas steel, which could consequently be used in several fields in which Martin steel had previously had the monopoly. ${ }^{11}$ ) After 1943 there was a distinction in Germany with regard to technique between the ordinary Thomas ingot steel on the one hand and the refined 'Austausch' steel on the other. In 1943 about a million tons of ingot steel of the latter refined variety were produced in Germany, which corresponded to barely $10 \%$ of the production of ordinary Thomas ingot steel. Apparently this proportion did not in-

\footnotetext{
$\left.{ }^{9}\right)$ Reichsvereinigung Eisen summed up the situation in a communication to the Reichsministerium für Bewaffung und Munition 29/1-43, as follows: 'Zusammenfassend ist zu sagen, dass die ausreichende Versorgung der Eisenschaffenden Industrie mit P-haltigen Rohstoffen ausschliesslich eine Transportfrage ist, während an Parmen Rohstoffen ein ausgesprochener Materialmangel besteht, der eine sorgfältige Beobachtung der jeweiligen Versorgungslage und eine entsprechende Stecierung erfordert'. R10III:52 (B A).

$\left.{ }^{10}\right)$ Janssen, pp. 73 f., Bericht des Herrn Bergassessor a.D.Dr. H. Winkhaus zur Frage des Erz- und Schrottpreisausgleiches, R13:I:385 (B A).

$\left.{ }^{11}\right)$ Klein, pp. 133 f., Reichswirtschaftsministerium, Jäger-Programm, T71:34:428351 ff. (N A). Reichsvereinigung Eisen, Tätigkeitsbericht für das Jahr 1943, T71:34:428525 (N A).
} 
crease in 1944 either. ${ }^{12}$ ) Thus the technical advancements did not provide any radical solution to the problem of the inadequacy of the supply of raw materials with a low phosphorus content. ${ }^{13}$ )

\section{The supply of scrap iron}

On an earlier occasion (p. 85) reference has been made to the great interest in Germany during the war in an increase in the supply of scrap iron, because of its coke-saving qualities. Since scrap iron also had great advantages as a raw material for the manufacture of high quality steel products, this interest naturally increased more and more. Finally, the development in the price of scrap iron favoured it as against iron ore. ${ }^{14}$ )

In an earlier chapter it has been shown that the yearly imports during the period before the outbreak of war, from Great Britain and the U.S.A. among other places, amounted to about 1 million tons. After the outbreak of war the German steel industry had to rely on sources in Germany or in the conquered areas. As was apparent from the earlier account of the German scrap iron supply (p. 25) the attempt to increase the supply of scrap iron to any greater extent was unsuccessful. Only in 1943, when there was an increase in the supply of scrap iron due to Speer's scrap iron campaign and to supplies from Eastern Europe, could the situation be regarded by the politicians responsible as satisfactory from this point of view. ${ }^{15}$ ) However, the inadequacy of the scrap iron supply was throughout a source of anxiety for the steel industry. ${ }^{16}$ )

\footnotetext{
${ }^{12}$ ) Stahlerzeugung in Deutschland und in den von Deutschland besetzten Ländern, T84:41:1319495 (N A), Reichsvereinigung Eisen, Hauptabteilung Statistik, Rohstahlerzeugung nach Sorten 1943, okt.-dec. 1944, T84:41:1322834, 869 ff. (N A).

${ }^{13}$ ) One possible way of increasing the production of Martin steel was to permit an increase in the phosphorus content of the steel at the expense of a lower quality. Niederschrift zur 10:e Besprechung der Zentralen Planung 15/7-42, FD, Handakten Milch, vol. 46 (IWM).

${ }^{14}$ ) As stated earlier, the price of imported iron ores rose sharply at the outbreak of the war, while the price of scrap iron remained stable, Statistisches Handbuch von Deutschland 1928-44, p. 466.

$\left.{ }^{15}\right)$ Reichsvereinigung Eisen, Tätigkeitsbericht für das Jahr 1943, R10III:8 (B A), Deutschlands Rüstung, p. 197.

${ }^{16}$ ) E.g. Eisenwirtschaft seit Kriegsausbruch, pp. $52 \mathrm{ff}$. R10III:6 (B A), Reichsvereinigung Eisen to Reichsministerium für Bewaffnung und Munition 29/1-43, R10III:53 (B A).
} 
Certainly it was possible to increase the part played by scrap iron in the feeding of the blast furnaces through additional premiums, ${ }^{17}$ ) but-in spite of all the efforts-scrap iron never became an effective means of overcoming the shortage of raw materials with a low phosphorus content.

\section{The supply of grades of iron ore with a low phosphorus content}

Thus neither economising nor technical innovations nor the supply of scrap iron could effectively assist in compensating for the shortage of raw materials with a low phosphorus content for the production of high quality steel. This made it a more urgent task for the politicians responsible in Germany to maintain or preferably increase the production and importation of these grades of iron ore.

Extensive efforts were of course made to increase production in Austria. In fact the Austrian iron ores had a low iron content of about $30 \%$ which was further reduced, however, because of the accelerated mining. ${ }^{18}$ ) Like all other iron ores with a low iron content these iron ores also became comparatively more expensive to use in production. Above all a shortage of labour hampered a further rise in production in Austria. ${ }^{19}$ )

German interest would therefore have to be directed mainly towards the imports. After the imports from North Africa had almost completely disappeared, those from Spain, Norway, Sweden and also for a short period the conquered areas of the Soviet Union continued.

As has been mentioned earlier, the production of iron ore in Spain had already declined considerably during the civil war and in the chaotic conditions which also prevailed during the years which followed produc-

\footnotetext{
$\left.{ }^{17}\right)$ Deutschlands Rüstung, p. 197. From the first six months of 1942 to February 1943 the consumption of scrap iron in loading the blast furnaces rose from $6 \%$ to $12 \%$ in the production of pig-iron. Reichsvereinigung Eisen, Vermerk betr. Entwicklung der Eisenerzeugung, des Schrotts- und des Roheisens-Verbrauches 1942, R10III:79 (B A). In the autumn of 1944, after the deliveries from Sweden had ceased, scrap iron may have constituted $40 \%$ of the loading of blast furnaces. Reichsvereinigung Eisen zur Lage 28/9-44, T71:34:428500 (N A).

$\left.{ }^{18}\right)$ Reichsvereinigung Eisen, Phosphorarme Erze, Bilanz 1943, 27/3-43 R10III:76 (B A). Hitler explained 1943 the increased iron ore mining: 'Im besonderen soll der Eisenerzberg in der Ostmark auf keinen Fall geschont werden.', Deutschlands Rüstung, p. 238.

$\left.{ }^{19}\right)$ Reichswirtschaftsministerium, Steigerung der Eisenerzförderung am Erzberg 11/5-44, Bericht über den Steirischen Erzberg 14/6-44, R7VII:129 (B A).
} 
tion was further reduced. Thus the Spanish production of iron ore fell from 3.2 million tons in 1939 to just over 1.6 million tons a year in 1941-1942 and the quantities for export had to be taken partly from existing stocks. ${ }^{20}$ ) Neither were the Spanish exports of iron ore to Germany characterised by the stability which for example distinguished the Swedish deliveries, but gave the impression to a greater extent of improvisation. ${ }^{21}$ ) The actual transport was expensive and had to be carried out partly by rail through France. ${ }^{22}$ ) Furthermore Germany was not the only importer of Spanish iron ore. During the whole of the war there were exports-greatly reduced, certainly, in comparison with the pre-war period, but regular-to Great Britain. ${ }^{23}$ )

The Norwegian iron ore mines - the most important was Sydvaranger, situated farthest to the north-contained ores with a low phosphorus content. However, the Norwegian iron ore was also characterised by a

$\left.{ }^{20}\right)$ Apparently there was great confusion at the Spanish iron ore mines, and part of the labour force left. Reichsvereinigung Eisen, Phosphorarme Erze, Bilanz 1943, 27/3-43, R10III:76 (B A), Reichswirtschaftsministerium, Bergbau Spaniens Mai 1943, R7VII:136 (B A). The Spanish production and exports of iron ore developed in the following way from 1936 to 1942 (million tons of ore):

\begin{tabular}{ccccccc}
\hline Year & Production & Exports & & Year & Production & Exports \\
\cline { 1 - 1 } 1936 & 2.3 & 1.7 & & 1940 & 2.2 & 0.8 \\
1937 & 1.3 & 0.8 & & 1941 & 1.6 & 0.6 \\
1938 & 2.5 & 1.1 & & 1942 & 1.8 & 0.7 \\
1939 & 2.4 & 1.3 & & & \\
\hline
\end{tabular}

Source: Reichswirtschaftsministerium, Bergbau Spaniens, R7VII: 138 (B A).

${ }^{21}$ ) Reichsvereinigung Eisen, Bericht 31/3-43, R10III:76 (B A). The conditions of importing from Sweden were put forward as an example which ought to be followed. Reichsvereinigung Eisen, Erzabteilung, R10III:76 (B A). As an example of the unpredictability of the Spanish iron ore exports it may be observed that deliveries which had left Spain in October 1943 had not yet reached the Ruhr in February 1944. Speer to Ganzenmüller 8/2-44, R10III:53 (B A).

${ }^{22}$ ) The rail freights were about $75 \%$ higher than the sea freights. Reichswirtschaftsministerium, Prüfungsstelle Frachten 28/4-43, T71:85:388625 (N A).

${ }^{23}$ ) Reichsministerium für Bewaffnung und Munition, Eisenerze, Lagebericht zur spanischen Eisenerzförderung und -ausfuhr unter besonderer Berücksichtigung der britischen Bezüge 19/7-44, R3:1655 (B A). During the period 1941-1943 almost $45 \%$ of the Spanish iron ore exports went to Great Britain. Estadistica del commercio exterior de España. 
low iron content, and in order to meet the cost of transport to Germany the iron ore had to be concentrated and made into briquettes. ${ }^{24}$ ) For this imported fuel was needed, which, with the previously documented German shortage of coal and freight space, was difficult to supply. To this must be added the fact that the coal as well as the iron ore had to be carried on the North Sea, where the risk of attack by the allies was great. ${ }^{25}$ )

Consequently the Norwegian mining companies did not experience during the war the period of prosperity which would otherwise have been expected. In several of the mines-among them Sydvarangermining was periodically discontinued during the war years and exports to Germany, which had amounted to just over half a million tons (tons of iron) during the pre-war years, were reduced during the war to about half. ${ }^{26}$ )

In Germany great hopes were attached to deliveries of grades of iron ore with a low phosphorus content from the conquered areas in the east, primarily from Krivoj-Rog. However as a result of destruction by the Russians no real mining was started in these mines, and instead

$\left.{ }^{24}\right)$ Norges Offisielle Statistik, Norges Bergverksdrift 1935-1944.

${ }^{25}$ ) In the Norwegian official reports the shortage of coal was put forward as the most important cause of the standstill at Sydvaranger. Sydvaranger usually required about 4,500 tons of coal a month and a round voyage with a convoy in 1943 took 3-4 months to complete, and so 4 medium-sized vessels had to be regularly engaged in this traffic if the mining was to be maintained. Reichswirtschaftsministerium, Vermerk für Herrn Präsident Kehrl 17/5, 8/6-43, T84:90:1380944 ff. (N A), Speer to Terboven 24/6-43, T84:106:1400869 f. (N A).

$\left.{ }^{26}\right)$ Reichsvereinigung Eisen, Phosphorarme Erze, Bilanz 1943, R10III:76 (B A). The Norwegian production of iron ore developed as follows in 1937-1944 (million tons of ore):

\begin{tabular}{llllll}
\hline Year & Production & & Year & Production \\
\cline { 1 - 1 } \cline { 5 - 6 } 1937 & 1.1 & & 1941 & 0.6 \\
1938 & 1.5 & & 1942 & 0.3 \\
1939 & 1.4 & & 1943 & 0.3 \\
1940 & 0.7 & & 1944 & 0.3 \\
\hline
\end{tabular}

Source: Norges Offisielle Statistik, Norges Bergverksdrift 1937-1944. 
the deliveries had to be taken from existing stocks. Owing to the great transport difficulties this import was also kept down. ${ }^{27}$ )

Therefore the only country which managed to satisfy to an increased extent Germany's need of iron ores with a low phosphorus content during the war was Sweden. Already in the autumn of 1939 there were promptings from Germany to make deliveries of iron ores with a low phosphorus content on the largest possible scale. ${ }^{28}$ ) In 1936 Swedish exports of these grades had amounted to 870,000 tons (tons of iron). After the outbreak of war these exports increased sharply and in 19401943 they amounted to just over 1.5 million tons a year. Therefore the proportion of iron ore with a low phosphorus content in the total Swedish exports of iron ore to Germany rose from $18 \%$ in 1936 to $27 \%$ in $1940-1943 .{ }^{29}$ ) This sharp rise in the deliveries to Germany was partly due to the fact that the earlier Swedish exports to Great Britain, which consisted to a large extent of grades with a low phosphorus

${ }^{27}$ ) Because of extensive Russian blastings in the pits-there was only underground mining - and the removal of materials, the mining could not start before extensive repairs and substantial investments had been made. Wirtschaftsgruppe Eisen schaffende Industrie, Erster Arbeitsbericht der Berg- und Hüttenwerksgesellschaft Ost mbH, T84:124:1423855 ff. (N A), Reichsvereinigung Eisen, Phosphorarme Erze, Bilanz 1943, R10III:76 (B A).

${ }^{28}$ ) Trafikaktiebolaget Grängesberg-Oxelösund styrelseprotokoll 16/12-39 (G A).

${ }^{29}$ ) The official trade statistics did not distinguish the phosphorus content in the iron ore trade. According to a German report the following quantities of iron ore with a low phosphorus content were exported from Sweden to Germany:

\begin{tabular}{|c|c|c|c|c|c|c|}
\hline \multirow[t]{2}{*}{ Year } & \multicolumn{2}{|c|}{ Central Sweden } & \multicolumn{2}{|c|}{ Norrbotten } & \multicolumn{2}{|c|}{ Total } \\
\hline & $\begin{array}{l}\text { million } \\
\text { tons of } \\
\text { ore }\end{array}$ & $\begin{array}{c}\% \text { of } \\
\text { total } \\
\text { exports }\end{array}$ & $\begin{array}{l}\text { million } \\
\text { tons of } \\
\text { ore }\end{array}$ & $\begin{array}{c}\% \text { of } \\
\text { total } \\
\text { exports }\end{array}$ & $\begin{array}{l}\text { million } \\
\text { tons of } \\
\text { ore }\end{array}$ & $\begin{array}{c}\% \text { of } \\
\text { total } \\
\text { exports }\end{array}$ \\
\hline 1935 & 0.5 & 26 & 0.7 & 20 & 1.2 & 22 \\
\hline 1936 & 0.7 & 30 & 0.8 & 13 & 1.5 & 18 \\
\hline 1940 & 1.6 & 50 & 1.0 & 17 & 2.6 & 29 \\
\hline 1941 & 1.8 & 45 & 1.0 & 14 & 2.8 & 25 \\
\hline 1942 & 1.8 & 51 & 0.7 & 14 & 2.5 & 30 \\
\hline 1943 & 1.8 & 48 & 0.7 & 12 & 2.5 & 25 \\
\hline
\end{tabular}

Source: Reichwirtschaftsministerium, Schwedenerz-Ausfuhr nach Deutschland, R7X:46 (B A). 
content, ceased from 9 April 1940, but the main reason was the comparatively sharp rise in the production of these grades in Sweden during the war years. ${ }^{30}$ )

Iron ores with a low phosphorus content were to be found in the large Norrbotten mines in Kiruna and Gällivare as well as in a large number of smaller iron ore mines in central Sweden. However the geology of the Norrbotten mines was such that it was not possible to mine only low phosphorus grades because there was always a certain relationship between the grades with a low phosphorus content and those with a high phosphorus content. An increase in the deliveries of iron ores with a low phosphorus content from Norrbotten would therefore also have meant an expansion in mining, and the exporting of iron ores with a high phosphorus content, which it would hardly have been possible to achieve, given the shortage of tonnage mentioned above (p. $71 \mathrm{ff}) .^{31}$ )

On the other hand several of the smaller iron ore mines in central Sweden-some of which were owned by German steel works-could have extended their exports of iron ores with a low phosphorus content considerably, or could have begun such an expansion. ${ }^{32}$ ) While low

30) The production of iron ores with a low phosphorus content (under $0.1 \%$ ) in Sweden in the years $1936-1939$ was almost exactly $20 \%$ of the total iron ore production. After that it rose to $27 \%$ in 1940 and $29 \%$ in the years 1941-1944. SOS, Bergshantering 1936-1944. On the export of iron ores with a low phosphorus content to England, PM 1/9-38, H40Ct (UD A).

${ }^{31}$ ) Reichsvereinigung Eisen, Phosphorarme Erze, Bilanz 1943, R10III:76 (B A).

${ }^{32}$ ) Amongst the larger export mines in central Sweden were inter alia-apart from the Grängesberg field—the Idkerberg, Ställberg, Stripa, \Striberg, Riddarhyttan, Bastkärn, Norberg and Dannemora, all of which were Swedish owned. It is worth noting that mining in the last named mine, due to the low phosphorus content in the iron ore has been classic for the Swedish iron industry, expanded substantially during the war and was orientated towards exports. The owners, Fagersta Bruks AB, on the basis of the favourable export prices of this iron ore, chose to buy iron ore from other places instead. Wretblad, pp. 501, 503.

In the area round Ludvika there were a number of mines which were under common management and were owned by the German steel works Hoesch AG in Dortmund with Fried. Krupp AG as minority shareholder $(33 \%)$. These included Bergverks $\mathrm{AB}$ Vulcanus, which operated mines in the Blötberg, Håksbergs Nya Gruv AB, Gruv AB Lekomberg and AB Stollberg's mines. Fr. Krupp AG, Geschäftsbericht der Hauptverwaltung des Erzbergbaues 1943/44, FD 2459/44 (IWM). Stora Långviks Gruv AB was also German owned (Vereinigte Stahlwerke, Düsseldorf) and it operated Intrånget's mines, the ores of which were characterised by the very low phosphorus content (under $0.01 \%$ ). During the war this company also developed Småland's 
phosphorus grades accounted for $30 \%$ of the exports to Germany from central Sweden in 1936, the proportion increased during the war years to just under $50 \%{ }^{33}$ ) These increased deliveries of iron ores with a low phosphorus content slowly led to a certain uneasiness within the foundry circles of central Sweden, where they began to fear that they themselves might be short of this type of iron ore in the future. ${ }^{34}$ )

Taberg, the ore of which was wanted in Germany because of its vanadium content. According to one estimate the German owned mines in central Sweden accounted for $17 \%$ of the lump ore production and $18 \%$ of the ore concentrate production in this area in 1942. Första Kammarens protokoll 1943, nr 35, p. 19. The German administration showed great interest in the mines owned abroad, see e.g. Reichswirtschaftsministerium, Stand und Entwicklung der von deutschen Firmen in europäischem Ausland betriebenen Bergwerke, R7VII:125 (B A).

On the whole the war years meant a certain re-structuring of Swedish iron ore production and exporting, which was due at least partly to the German demand for grades with a low phosphorus content. While iron ore mines not belonging to the Grängesbergsbolag had exported about $800,000-1,000,000$ tons (tons of ore) a year in the 1930's, these exports were doubled during the war. The Swedish production of iron ore with a low phosphorus content showed the following development in 1936-1944 (million tons of ore):

\begin{tabular}{cccc}
\hline Year & Central Sweden & Norrbotten & Total \\
\hline 1936 & 0.9 & 1.1 & 2.0 \\
1937 & 1.2 & 1.5 & 2.6 \\
1938 & 1.3 & 1.3 & 2.6 \\
1939 & 1.2 & 1.3 & 2.6 \\
1940 & 1.6 & 1.2 & 2.7 \\
1941 & 1.8 & 0.8 & 2.6 \\
1942 & 1.8 & 0.7 & 2.5 \\
1943 & 1.8 & 0.9 & 2.8 \\
1944 & 1.1 & 0.6 & 1.6 \\
\hline
\end{tabular}

Source: SOS, Bergshantering 1936-1944.

Note 1: Iron ores with a low phosphorus content are those with less than $0.1 \%$.

${ }^{33}$ ) See note 29 above.

${ }^{34}$ ) The discussion was prompted by a lecture given by the engineer Karl Rutberg at Stora Kopparbergs Bergslags AB in December 1943 and it led to a government inquiry into Sweden's deposits of iron ores with a low phosphorus content. Affärsvärlden 1943, pp. 934 ff., 954 f., 1,000, Första kammarens protokoll 1943, nr 35, pp. $18 \mathrm{ff}$. In Germany it was believed that the initiative stemmed from M. Waldenström in the Grängesbergsbolag, who wanted to avoid competition from other mines, and from J. Wallenberg, a member of the Swedish delegation negotiating with Germany, and therefore that the campaign was directed politically and economically against Germany. Auswärtiges Amt to Reichswirtschaftsministerium 14/6-44 with supplements, R7X:46 (B A). 


\section{Summary}

It is possible to establish beyond debate that the supply of iron ore to the German steel industry during the war years constituted in a particular respect a serious and highly significant bottleneck, viz. as regards grades of iron ore with a low phosphorus content for the production of certain kinds of high quality steel. Contemporary statements about this matter are innumerable, and comment is made with equal frequency on the great advantage it was to Germany's armament industry that Sweden managed to increase her deliveries of this particular grade. The Swedish concessions were of course dictated by political reasons. ${ }^{35}$ )

In the revised sources no compilation-apart from a few optimistic forecasts-has been found regarding the actual supply of grades of ore with a low phosphorus content. Therefore the following table, in which the net scrap iron supply is also given, is somewhat tentative.

Table 37. Germany's supply of iron ore with a low phosphorus content and net scrap iron in 1938 and 1941

(million tons of iron)

\begin{tabular}{|c|c|c|c|c|}
\hline & \multicolumn{2}{|c|}{1938} & \multicolumn{2}{|c|}{1941} \\
\hline & Iron ore & Net scrap iron & Iron ore & Net scrap iron \\
\hline \multicolumn{5}{|l|}{ Domestic } \\
\hline Siegerland & .. & & 0.5 & \\
\hline Purple ore & .. & & 0.5 & \\
\hline Austria & - & & 0.8 & \\
\hline Total & . & 2.5 & 1.8 & 3.0 \\
\hline \multicolumn{5}{|l|}{ Imports } \\
\hline Sweden & 0.9 & & 1.5 & \\
\hline Norway & 0.7 & & 0.3 & \\
\hline Spain & 0.5 & & 0.4 & \\
\hline North Africa & 0.7 & & 0.1 & \\
\hline Total & 2.8 & 1.1 & 2.3 & 0.9 \\
\hline
\end{tabular}

Source: 1938 see table 13 above p. 34, and also Schwedenerz-Ausfuhr nach Deutschland, R7X:46 (B A), 1941 see tables 22-25 above p. 49 ff and the sources stated there.

${ }^{35}$ ) In May 1940 the German ore negotiator Wenzel (Vereinigte Stahlwerke) said: 'Die Schweden erklärten ohne weiteres bereit zu sein, so viel wie nur eben möglich phosphorarme Erze zur Verfügung stellen zu wollen'. OKW, WiRüAmt, Vermerk 
It is clear from the table that the low phosphorus Swedish iron ore became very important and of course the Germans tried to stimulate exports in every way. The grades with a low phosphorus content were always given priority in the Swedish-German trade negotiations, and the price increases allocated to the Swedish iron ore related almost without exception to the iron ore with a low phosphorus content. ${ }^{36}$ ) The Germans were also prepared at times to deliver war materials merely in exchange for Swedish iron ore with a low phosphorus content. ${ }^{37}$ )

über die Stockholmer Verhandlungen 7-9 Mai 1940, T77:699:1911542 ff. (N A). See also note 9 above. In another statement from Reichsvereinigung Eisen it was said: 'Während der Mehrbedarf an phosphorreichen Erzen für die geplante Kontingentserzeugung aus inländischer Förderung ohne weiteres aufgebracht werden kann, besteht ... auf der P-armen Seite eine erhebliche Unterdeckung'. Reichsvereinigung Eisen to Speer 10/4-43, R10III:86 (B A), Reichswirtschaftsministerium, Vermerk 4/11-43, R7VII:383:1 (B A).

$\left.{ }^{36}\right)$ Protokoll über Besprechungen des deutschen und des schwedischen Regierungsausschusses für Fragen des Zahlungs- und Warenverkehrs zwischen Deutschland und Schweden 28/11-19/12-41, 7-18/12-42, 10/12-43-10/1-44, HK vol. 352 (R A). Trafikaktiebolaget Grängesberg-Oxelösund styrelseprotokoll 3/12-41, 22/12-43 (G A).

When Sweden after pressure from the English and Americans limited the quantity of exports to 7 million tons for the year 1944, the Germans nevertheless considered themselves satisfied as far as the various types of ore were concerned, i.e. with a comparatively high proportion of iron ores with a low phosphorus content. OKW, WiRüAmt T77:693:1902660 (N A), Vortrag Dr Rohland 23/3-44, T71:34:428551 ff (N A). The quality aspects was never referred to by the English or the Americans in their negotiations with the Swedish Foreign Office. All types of ore always made them 'see red'. It appears that they had completely misunderstood the situation. In an investigation by the Ministry of Economic Warfare 4/1-40 it was suggested that it was precisely the high phosphorus content of the Swedish iron ore which was important, since Germany herself had such a good supply of iron ores with a low phosphorus content. N347/19/63 (P R O).

${ }^{37}$ ) In a 'Führerbesprechung' Speer gave the following arithmetical example to demonstrate that deliveries of armament materials to Sweden in exchange for iron ores with a low phosphorus content would be a good business proposition for Germany: 'Der Preisunterschied zwischen Eisenerz und Rüstungsgut ist ein so ausserordentlicher, dass bereits mit geringen Waffenlieferungen eine grosse Erzmenge abgedeckt werden kann. So kostet z.B. ein Panzer 4250000 RM, eine Tonne Erz 10-20 RM. Der Panzer hat ein Einsatsgewicht von 40 to., so dass ein Panzer wertmässig 12,500 to. Erze (RM 20) bringt somit Stahl (bei $65 \%$ Fe-Gehalt) für 200 Panzer'. Speer's Führerbesprechung 11/11-43, R3:1514 (B A), Reichsvereinigung Eisen, Aktennotiz 5/11-43, R10III:53 (B A). 
The importance of the grades with a low phosphorus content is perhaps best illustrated by an analysis which was made within the Reichsvereinigung Eisen of what a stoppage of the Swedish iron ore deliveries would mean to the German steel industry. While it was considered possible to compensate for the loss of the Swedish iron ores with a high phosphorus content by an increase in the mining of other iron ores, e.g. minett ore, it was stated in the analysis that the important Swedish iron ore with a low phosphorus content was 'nicht ersetzbar' for the production of quality steel. ${ }^{38}$ )

${ }^{38}$ ) Reichsvereinigung Eisen, Auswirkungen eines evtl. Ausfalles skandinavischer Erze 26/2-43, R10III:76 (B A), Ausfall skandinavischer Erze 1/3-43, R10III:78 (B A), Ausfall an Schwedenerzen 24/8-44, R10III:53 (B A). 


\section{SWEDEN'S IRON ORE EXPORTS AND WAR TRADE POLICY}

\section{A. Introduction}

As shown in an earlier chapter of this research, the Swedish exports of iron ore to Germany were a subject of great interest politically to the warring powers during the second world war. Of course the iron ore exports also played an important role in Swedish trade and foreign policy. However, the Swedish government had for years been involved in the exporting of iron ore (owning from 1907 a half share in Sweden's two largest iron ore mines, Kiruna and Gällivare), but because the exports were increasingly bound up with politics, the government's interest in controlling and regulating activities quite naturally increased. 'No other exports can expose us to such great risks as the exports of iron ore'. $\left.{ }^{1}\right)$

During the war years trade negotiations between Sweden and Germany were also to take place on two different levels. Spokesmen for the Swedish export mines (ore sellers) and for the German steel works (ore buyers) were above all negotiating about technical questions of minor importance and they had to act as a group of experts to whom matters could be referred. The more important questions relating to export quantities and prices were discussed at the superior government commissions, which were also the contracting parties. The government commissions' way of dealing with the question of prices at times caused great bitterness among the ore exporters. ${ }^{2}$ )

$\left.{ }^{1}\right)$ During the interwar period the Swedish Foreign Office came to the conclusion that the government ought to take responsibility for the control of foreign trade in its entirety. Hägglöf, pp. $14 \mathrm{ff}$., Sohlman, pp. $65 \mathrm{f}$. The quotation from a memorandum on measures taken in connection with Sweden's foreign trade in the event of a war or a crisis 1/9-38, H40Ct (UD A).

$\left.{ }^{2}\right)$ Trafikaktiebolaget Grängesberg-Oxelösund styrelseprotokoll 12/2-40, 21/12-42 (G A), Mallet to Eden 23/12-40, N 7530/24/42 (P R O). 
The principal features of Swedish trade policy during the second world war have been thoroughly investigated in Gunnar Hägglöf's well-informed work Svensk krigshandelspolitik under andra världskriget, in which much attention is devoted to the exports of iron ore from Sweden. ${ }^{3}$ ) In the present chapter, however, the Swedish war trade policy will be discussed partly from other viewpoints and partly in the light of other sources. The iron ore exports constitute the axle round which the other questions are grouped.

The following table will serve to give an immediate idea of the extent of the iron ore exports in terms of value, and their relationship to the rest of the Swedish exports:

Table 38. The Swedish exports in 1936-1944

(million kronor and \%)

\begin{tabular}{lccccc}
\hline Year & $\begin{array}{c}\text { Total exports } \\
\text { (million kronor) }\end{array}$ & $\begin{array}{c}\text { Exports to } \\
\text { Germany } \\
\text { (million } \\
\text { kronor) }\end{array}$ & $\begin{array}{c}\text { Exports to } \\
\text { Germany as } \\
\text { \% of total } \\
\text { exports }\end{array}$ & $\begin{array}{c}\text { Iron ore } \\
\text { exports to } \\
\text { Germany as } \\
\% \text { of total } \\
\text { exports }\end{array}$ & $\begin{array}{c}\text { Iron ore } \\
\text { exports to } \\
\text { Germany as } \\
\% \text { of total } \\
\text { exports to } \\
\text { Germany }\end{array}$ \\
\hline $1936 / 38$ & 1786 & 301 & 17 & 8 & 46 \\
1939 & 1888 & 371 & 20 & 10 & 50 \\
1940 & 1328 & 494 & 37 & 12 & 32 \\
1941 & 1345 & 558 & 41 & 12 & 28 \\
1942 & 1319 & 529 & 40 & 11 & 28 \\
1943 & 1172 & 537 & 46 & 16 & 34 \\
1944 & 853 & 345 & 40 & 10 & 25 \\
\hline
\end{tabular}

Source: SOS, Handel

Thus Germany's share of Sweden's total exports increased considerably during the war years. This was partly due to a sharp increase in the exports there in terms of value, but also to a reduction in the volume of foreign trade generally. Before the war broke out iron ore was clearly the dominant product exported to Germany (almost half of the export

\footnotetext{
${ }^{3}$ ) Apart from his experience in his job as head of the trade policy department at the Swedish Foreign Office (UD) during the greater part of the war, Hägglöf has also drawn on Swedish Foreign Office documents. In the following account there will not be a reference to Hägglöf in every individual case.
} 
value), whereas during the war the share fell to about $30 \%$. The paradox is that the iron ore exports to Germany during the second world war lost some of their comparative importance in terms of value while at the same time acquiring an unprecedented importance in political terms.

However it is perfectly clear that the Swedish iron ore exports in other respects cannot be considered in isolation from trade and foreign policy. ${ }^{4}$ ) Changes within the exports of iron ore caused, or were in turn caused by, changes in other spheres of trade policy or in foreign policy generally. Viewed in this way the iron ore exports constituted one of the many means of exerting pressure, political as well as economic, which were exploited during the second world war. In German domestic diplomatic language a suitable term for this was in use, viz. 'Daumenschrauben' (thumb-screws). For the various parties it was a question of having the opportunity to tighten certain screws in order to achieve the desired results. The changes in the realities of foreign and trade politics determined which party could tighten the most sensitive screws the most at the time. It is from this aspect that the Swedish exports of iron ore are examined in the account which follows.

What thumb-screws could be used against Sweden? On the other hand, what were Sweden's trump cards?

It is possible to compile a very long list of these but it will still not be beyond dispute since the various means of applying pressure constantly changed in character and strength. Only some of the more important ones will be mentioned here.

The German thumb-screws on Sweden operated both in the political and economic spheres. The German deliveries of coke and coal were considered to be basic necessities for Swedish economic life. In addition Sweden imported a large number of important products. German deliveries of war materials - and not least promises of such deliverieswere also a useful means of bringing pressure to bear. Finally Germany also exercised control over the so-called Gothenburg traffic. On the political level German military superiority during the first years of the war obviously constituted a source of strength.

The Swedish trade and political trump cards consisted of a number

${ }^{4}$ ) For Sweden's foreign policy see Carlgren, who without adding many new facts, also incorporates trade policy into his account. Carlgren, p. 27, note 6. 
of products which were of interest to Germany, above all iron ore and ballbearings. On the general political level Sweden could also use the German transit traffic through Sweden to Norway and Finland as a thumb-screw. Germany's increasing military weakness during the latter part of the war was also exploited by the Swedish negotiators.

The principal economic means of pressure by the allies on Sweden lay above all in the goods which Sweden was allowed, with the consent of the British, to import via Gothenburg, mainly oil and rubber, together with promises of deliveries of certain war materials. With an increase in their military strength from 1943 the negotiating position of the allies was strengthened and gradually threats were made about special treatment of Sweden in the future, and confiscation of Swedish property abroad and blacklisting of Swedish companies were suggested.

During the greater part of the war Sweden had no economic means of putting pressure on Great Britain (up to 9 April 1940 imports of iron ore and steel from Sweden were considered by the British to be of great importance). Instead, Sweden had to exploit the military weakness of the allies during the first years of the war.

\section{B. The period up to the outbreak of war}

It was apparent within the Swedish Foreign Office for several years before the outbreak of the second world war that the Swedish exports of iron ore to Germany were of such a sensitive nature that they would cause political difficulties for Sweden in a possible conflict of high politics. In articles which had great coverage and were often highly exaggerated, and which appeared in the Swedish as well as in the foreign press, the German dependence on Swedish iron ore was stressed, and there were speculations about the consequences of this for foreign politics. The speculations were nourished to some extent by the almost simultaneous proposals from England and Germany to Sweden, during the boom year of 1937, for increased deliveries of iron ore. The requirements of England were dictated above all by the fact that deliveries from Spain had quite naturally been severely reduced. ${ }^{5}$ ) The blockade theory, i.e. that of attempting to reduce Swedish exports to Germany through personal purchases, was not so predominant on this occasion. ${ }^{6}$ ) By

5) See above, p. $36 \mathrm{f}$.

$\left.{ }^{6}\right)$ Palmstierna to Sandler 10/5-37, H40Ba (UD A). 
the intervention of the Swedish government in the shape of changes in the law, increased exports to Germany as well as Great Britain were made possible. However the slump in 1938 caused a decline in England's interest in Swedish iron ore, and in spite of reminders from the Swedish Foreign Office, who wanted a more even distribution of exports to Germany and Great Britain, the agreed quantities were not collected. ${ }^{7}$ )

In the spring of 1939 England's interest in Swedish iron ore was increasing again. However, at this time the behaviour of the English was entirely dictated by the blockade theory. In order to reduce German imports of Swedish iron ore substantial orders were planned in Sweden, which was something which the Swedes also found desirable in order to resist expected German demands for increased imports of iron ore. ${ }^{8}$ ) The English were emphatically maintaining an attitude to Swedish iron ore which was to assert itself throughout the war, viz. that a stoppage of the Swedish deliveries of iron ore to Germany would be a staggering blow to the enemy's steel industry and would therefore constitute perhaps the most effective blockade weapon which the allies had against Germany. ${ }^{9}$ )

During the spring and summer of 1939 the Swedish Foreign Office also received constant reports about the great importance which was attached abroad to the Swedish exports of iron ore. At times the tone became rather hostile. 'I am afraid we have to destroy your mines' was once a well-known expression of an English diplomat in the spring of $1939 .{ }^{10}$ ) At about the same time a German diplomat let fall that

$\left.{ }^{7}\right)$ Söderblom to Prytz 14/7-38, H40Ba (UD A). When the English returned in the spring of 1939 the Swedish Foreign Minister expressed his disappointment with England's behaviour. Hudson to Halifax 1/3-39, Memorandum 1/4-39, N1189/1189/42, N1842/1818/42 (P R O).

${ }^{8}$ ) A record kept by the British Minister for Foreign Trade permits us to assume that it concerned the whole of the Swedish iron ore exports. Hudson Memorandum 6/4-39, Ashton-Gatwin Memorandum 1/5-39, N/1910/31/63, N2238/31/63 (P R O). Prytz to Hägglöf 13/7-39 H40Ba (UD A).

$\left.{ }^{9}\right)$ On the British blockade policy see Medlicott, I, pp. $44 \mathrm{ff}$., $180 \mathrm{ff}$. At the beginning of September 1939 the English Member of Parliament Sir Ralph Glyn presented a memorandum to the Swedish envoy to London which ended with the following pathetic appeal: 'Probably there has never been a case in history of a state, itself remote from active participation in the war, having such a real opportunity of making decisions of stch an absolutely decisive character'. Hägglöf, p. 35.

$\left.{ }^{10}\right)$ Hägglöf, p. 27. 
if Sweden cancelled the ore exports Germany would take the ore, like Bohemia, by force. ${ }^{11}$ )

In the cross-fire between German claims for continuing and increased iron ore deliveries (which also created currency for Swedish imports from Germany) and English demands for a stoppage of the deliveries to Germany, Swedish trade policy was faced with great difficulties and had to show great flexibility and adaptability. A rigid adherence to stale principles of neutrality was considered quite impossible in this situation.

\section{From the outbreak of war to the 9 April 1940}

The actual outbreak of war did not cause any cuts in the Swedish deliveries of iron ore to Germany and Great Britain. Very soon, however, in order to regulate trade between the countries, parallel negotiations started between Sweden and Germany and between Sweden and Great Britain, the so-called double negotiations. In both cases the Swedish exports of iron ore were at the heart of the discussions, in which English negotiators tried to reduce, and German negotiators tried to increase, the deliveries. As Hägglöf's thorough investigation has shown, it was a question for the Swedish negotiators of fixing an upper limit to the exports to Germany which was acceptable to both parties.

In this context the long and complex sessions of negotiations during the autumn of 1939 will not be described. Instead the extent to which it was politically and economically possible for the various parties to lend force to their arguments will be examined.

The negotiating strength of the English (thumb-screw) lay in the country's ability to continue her deliveries to Sweden of certain important goods. In other respects the English negotiators had to appeal to the desire to safeguard common democratic values. ${ }^{12}$ ) The Swedish negotiators argued along the following lines vis-à-vis Great Britain. Germany's military superiority in northern Europe meant that Sweden felt it necessary to adopt a cautious attitude towards that country. Thus for Sweden the exporting of iron ore to Germany was more a political than an economic question. Germany's documented request that she might deliver goods of vital importance to the Swedish national economy

\footnotetext{
${ }^{11}$ ) Winther to Söderblom 17/4-39, H40Ct (UD A).

$\left.{ }^{12}\right)$ Boheman, pp. $85 \mathrm{ff}$.
} 
also entailed as a consideration the exporting of iron ore by Sweden. ${ }^{13}$ )

On the other hand in the simultaneous negotiations with the German government commission the Swedish negotiators had no particularly strong arguments in favour a reduction of the export quantities. Instead they had to prolong the negotiations until agreement had been reached with the English. ${ }^{14}$ )

At the start of the negotiations the German negotiators already showed a pronounced interest in the iron ore, while other subjects were of secondary significance. The German chief negotiator maintained 'that from the German point of view there was only one problem of real importance, and that was the iron ore'. ${ }^{15}$ ) Germany's readiness to deliver all kinds of goods to Sweden-among other things, thanks to the conquest of Poland, it would be possible to satisfy Sweden's total needs for coal and coke-was an extremely strong argument in the negotiations, especially as the imports from the West became smaller. The whole of the foreign political situation in the autumn of 1939 favoured the German negotiating position. ${ }^{16}$ )

On 19 October the English accepted that the quantity exported to Germany in the year 1938, 10 million tons, was to be applied as the maximum quantity to be exported in future years. This constituted a substantial concession from the stands which had been taken earlier and of course it was greeted with great satisfaction in Sweden since it enabled an agreement to be concluded with Germany. The fact that the English accepted the high export figure must have been due to their hopes that they would nevertheless be able to prevent exports via Narvik, the importance of which as a shipping port was greatly overrated in Great Britain. It was also assumed that the war would be short-lived. Before the ice outside Luleå broke up in May the war would be over, or the negotiating position would be different. Great importance also

\footnotetext{
${ }^{13}$ ) Ibid., Monson to Foreign Office 7/9-39, N4298/1189/42 (P R O), UD to the Swedish Minister in London 17/10, 26/10-39, HP64Ba (UD A).

${ }^{14}$ ) Hägglöf to Boheman 5/10-39, HP64Ba (UD A).

15) Ibid. PM angående samtal rörande de tysk-svenska handelsförbindelserna (Memorandum of conversations about Swedish-German trade connections) 26/9-39, HP64Ct (UD A).

$\left.{ }^{16}\right)$ Richert to Boheman 9/9-39, HP64Ct (UD A), Walter and Wied to Auswärtiges Amt 23/9-39, HaPol VI, Schweden, Handel 11, Nr 1, Bd2 (A A), UD to the Swedish Minister in London 26/10-39 HP64Ba (UD A).
} 
seems to have been attached to the Swedish promises not to make any technical improvements in Luleå in order to increase shipping on the Baltic, and also to make certain 'technical' preparations (e.g. calling up miners) in order to reduce imports. The only alternative-a situation in which no agreement was reached-was considered to be worse from the British point of view. Sweden could manage without imports from Great Britain, while certain Swedish exports (special steel, charcoal iron) were of great importance to Great Britain. A situation in which no agreement was reached would also cause a substantial loss of public support. ${ }^{17}$ )

Nevertheless, in discussion with the German representatives the Swedish negotiators adopted a very strict attitude-among other reasons, in order to extract advantages in other fields-and offered only 7 million tons a year. ${ }^{18}$ ) German military threats-of minelaying in Swedish territorial waters-persuaded the Swedish negotiators to weaken, and in December 1939 agreement was reached on deliveries of 10 million tons of iron ore during the year 1940. In actual fact however Sweden was pressed to exceed the limit in the agreement. For the year 1939 contracts were concluded between German buyers and Swedish export mines for a total of 11.5 million tons. In addition the Swedish negotiators had to accept in silence the drawing up of contracts for 11 million tons for the year 1940. Thus Sweden had to acquiesce tacitly in breaches of the earlier agreement with the English in the month of October. There was no mistaking the satisfaction of the Germans over the results achieved in the negotiations. ${ }^{19}$ )

However, English opposition to the Swedish iron ore deliveries to Germany did not cease after the agreement in October. There was mounting opposition to the terms of the agreement, and it was con-

${ }^{17}$ ) Foreign Office Memorandum 13/10-39, Memorandum by the Minister of Economic Warfare 31/10-39, N5162/1189/42, N6104/1189/42 (P R O). Medlicott, I, pp. 147, 152, Boheman, p. 87.

${ }^{18}$ ) Boheman to M. Wallenberg 11/11-39, HP64Ba (UD A).

$\left.{ }^{19}\right)$ Protokoll über Besprechungen der deutsch-schwedischen Regierungsausschüsse betreffend den deutsch-schwedischen Warenverkehr im Jahre 1940 vom 12/1-40, Anlage 1, Gutachten, Aufzeichnung über den Ausgang der deutsch-schwedischen Wirtschaftsverhandlungen von Dezember 1939/Januar 1940, HaPol VI, Handel 13A, Bd1 (A A). 
sidered that they were far too favourable to Sweden. ${ }^{20}$ ) The annoyance of the English increased when the quantities of iron ore exported by Sweden to Germany during the year 1939 were made known, viz. 10.9 million tons. Information about overtime at the Swedish export mineswhich was in breach of the promises made by Sweden in the autumnalso annoyed the English. ${ }^{21}$ )

However the Finnish winter war gave the allies an opportunity to combine aid to Finland with control over the iron ore mines in the north of Sweden. The latter aim was of course the principal one, and was considered by many people-including Churchill above all-to be extremely important. ${ }^{22}$ ) Parallel with attempts to get permission to march through Sweden the English tried, inter alia by promising to deliver war materials, to commit Sweden to firmer military co-operation. ${ }^{23}$ ) The arguments of the English were along the following lines: After Finland was defeated the Soviet Union would border on Sweden to the north. The advance positions would be considered by Germany to constitute such a serious threat to the iron ore deliveries from the north of Sweden that Germany would be compelled to resort to military intervention against Sweden. The Swedes-fully realising that the primary aim of the allies was not aid to Finland but control over the ore fields-in fact remained cool, and maintained that there were no reasons for Germany to attack Sweden, since the iron ore deliveries functioned so excellently just as they were. ${ }^{24}$ ) The slightest threat to the iron ore deliveries would-the Swedes maintained-bring about a successful German attack and 'Sweden might well be made a shambles

$\left.{ }^{20}\right)$ In Great Britain the internal criticism was directed against her own negotiators who had come from the industries. Hambro, whose bank did much business with Scandinavia, was considered to have been too co-operative. Sargent Memorandum 7/12-39, N7247/1189/42 (P R O).

${ }^{21)}$ Medlicott, I, p. 188, M. Wallenberg to Boheman 20/11-39, Prytz to Boheman 7/1-40, HP64Ba (UD A), Foreign Office to Monson 31/12-39, N58/19/63 (P R O).

${ }^{22}$ ) War Cabinet Conclusions 22/12-39, 29/2-40 (P R O). The literature on this is plentiful. Last thoroughly dealt with by Woodward, p. $42 \mathrm{ff}$.

${ }^{23}$ ) M. Wallenberg to Boheman 12/1, 14/1, 15/1-40. Uppteckning av Halifax' uttalande vid samtal med Prytz, (Record of Halifax's statements in conversation with Prytz) 19/1-40, HP64Ba (UD A), Stanley to Halifax 24/1-40, N1069/1069/42 (P R O), Medlicott, I, p. 186.

${ }^{24}$ ) UD to the Swedish Minister in London 20/1-40, M. Wallenberg to Boheman 24/1-40, HP64Ba (UD A), Mallet to Halifax 14/2-40, Mallet to Cadogan 4/3-40, N1943/9/56, N2872/9/56 (P R O). 
like Poland long before (allied) aid could be effective'. ${ }^{25}$ ) However from this point of view Sweden's interest in contributing to a quick end to the hostilities between Finland and the Soviet Union seems quite natural. ${ }^{26}$ )

The difficulties in the trade policy sessions between Sweden and Great Britain during the winter of $1939 / 40$ originated in the highly exaggerated view of the English about the great importance in the short run of Swedish iron ore, 'possibly the most important issue of Economic Warfare today' ${ }^{27}$ ) In addition, the real importance of the Swedish iron ore was misinterpreted (see above, chapter V, note 36). Sweden tried in every way, inter alia by giving international coverage to an article by the Swedish industrialist Gerard de Geer, to moderate this opinion. However she was not successful in convincing international opinion of the strength of the arguments. ${ }^{28}$ )

The Germans, however, had every reason to be satisfied with the results they had obtained in the negotiations with Sweden. The German negotiators considered that the Swedish government, although it had been under pressure from the English, was decidedly friendly towards Germany. ${ }^{29}$ ) A worrying sign that Sweden's ability to make deliveries was not assured was to be found in the increasing conscription of miners, crane-drivers, and other groups which were essential for the iron ore exports. In Germany the demands for the exemption of these groups of workers were increased little by little. ${ }^{30}$ )

${ }^{25}$ ) Mallet to Halifax 14/2-40, N1943/9/56 (P R O).

26) A Swedish 'Munich' would give Sweden time to build up a stronger defence against future Russian aggression. Mallet to Foreign Office, 24/2-40, N2331/9/56 (P R O). Mallet was also able to report strong Swedish pressure on Finland to accept Russia's terms. Mallet to Foreign Office 1/3-40, N2627/9/56 (P R O).

${ }^{27}$ ) Extract from a letter from Monson in M. Wallenberg to Boheman 20/11-39, HP64Ba (UD A). In the English documents, from the Foreign Office as well as from War Cabinet Conclusions, the proofs are innumerable.

${ }^{28}$ ) Documents in slip-case XVI, H40Ct (UD A), Monson to Foreign Office 5/6-39, N2910/31/63 (P R O). M. Wallenberg to Günther 25/2-40, HP64Ba (UD A). Müllern has based his account of Germany's slight dependence on Swedish iron ore on de Geer's article, Müllern, pp. $108 \mathrm{ff}$. According to Medlicott, de Geer's article was considered by the author himself to be 'all nonsens'. Medlicott, I, p. 191.

${ }^{29}$ ) Aufzeichnung über den Ausgang der deutsch-schwedischen Wirtschaftsverhandlungen vom Dezember 1939/Januar 1940, HaPolVI, Handel 13A, Bd 1 (A A).

${ }^{30}$ ) Wenzel to Walter 14/2-40 (copy), HP64Ct, Richert to Boheman 2/3-40, HP39HTy, Richert to Boheman 4/4-40, H40Ct (UD A). 


\section{From 9 April 1940 to the summer of 1943}

With the German attack on Norway and Denmark on 9 April 1940 Sweden's connections westwards were almost completely cut off, and Sweden could see herself enclosed in the magnitude of the German economy. The English had to recognise, not without bitterness, that their chances of influencing the volume and character of Sweden's iron ore exports had disappeared for several years to come. ${ }^{31}$ ) The Swedish negotiators now had only one party to negotiate with-but a superior one. Sweden's strength in the negotiations was to be found, just as before, in her ability to export to Germany interesting products at reasonable prices, primarily-but by no means exclusively-iron ore.

New trade agreements were made yearly between Sweden and Germany. In the discussions which preceded the signing of the agreements the German negotiators could emphasise their country's military successes and her continuing ability and wish to supply Sweden with important goods. A continuous exchange of goods featured in the more extensive German plans which aimed at a long term incorporation of Sweden into the magnitude of the German economy. The Germans were therefore anxious to maintain Sweden's ability to produce and deliver. ${ }^{32}$ ) On 9 April there was already discussion in the trade policy committee at the German Foreign Office about compensating Sweden for the loss of her English coal deliveries. ${ }^{33}$ ) Throughout the contemporary German analyses the great advantages of a peaceful and practical incorporation of Sweden into the Greater German economy were stressed. ${ }^{34}$ )

$\left.{ }^{31}\right)$ Memorandum Addis 21/6, 22/8, 30/10-40, N5010/24/42, N6295/24/42, N6971/24/42, Memorandum Collier 19/11-41, N6506/84/42 (P R O).

${ }^{32}$ ) On 10 April 1940 there was already a detailed statement 164 pages in length. OKW, WiRüAmt, Betrachtung der Wirtschaft der drei nordischen Staaten nach der Besetzung Norwegens und Dänemarks durch deutsche Truppen, T84:89:1379780 (N A), Ribbentrop to the German legation in Stockholm 18/4-40, Handakten Wiehl, Schweden Bd 5 (A A), Aufzeichnung des Gesandten Clodius 30/5-40, AzDAP, Ser. D, Bd IX, pp. $390 \mathrm{ff}$.

${ }^{33}$ ) Sitzung des Handelspolitischen Ausschusses am 9 Mai 1940, Handakten Wiehl, Schweden Bd 5 (A A).

${ }^{34}$ ) OKW, WiRü Amt, Betrachtung der Wirtschaft der drei nordischen Staaten nach der Besetzung Norwegens und Dänemarks durch deutsche Truppen, s. $163 \mathrm{f}$., T84:89:1379780 (NA). Aufzeichnung des Legationsrats van Scherpenberg 28/8-41, AzDAP, Ser. D, Bd XIII, s. $332 \mathrm{ff}$. 
The German deliveries of coal and coke to Sweden-in spite of the fact that there was a clearly documented shortage of these types of goods in Germany-fall easily into place in the larger pattern. ${ }^{35}$ )

However, in the renewed negotiations for a settlement in the summer of 1940 the Swedish negotiators were pressed to make certain concessions, among others the abandonment of the export quantities for 1938 as the standard. The English had to accept that the AngloSwedish agreement of the previous autumn had lapsed. ${ }^{36}$ ) In addition Sweden had to accept fairly sharp increases in the prices of coal and coke imports from Germany. ${ }^{37}$ )

In one very special respect Sweden's iron ore exports were in fact to be used as a means of putting pressure on Germany. This concerns Sweden's refusal in April 1940 to send weapons and many other things through Sweden to the troops fighting in Narvik. This refusal was countered by a German ban on exports of war materials, which was considered by the Swedes to be a very serious act of retaliation. The argument was then used as a Swedish counter thumb-screw that without imports of anti-aircraft devices and artillery from Germany Sweden would hardly be able to defend the north of Sweden against attacks by the allies, and the iron ore exports would also be in extreme danger. These arguments made an impression, but the question was resolved by the withdrawal of the English troops from the Narvik area. ${ }^{38}$ )

With the German advantage which was accentuated after 9 April, the demands, which have been mentioned above, for the exemption of the Swedish miners were intensified. Therefore during the summer of 1940 the Swedish military authorities had larger numbers of workers sent back on leave of absence to take part in the accelerated mining operations and the exporting of iron ore to Germany, whose own

\footnotetext{
${ }^{35}$ ) See above, p. 81 .

${ }^{36}$ ) Memorandum Addis 21/6-40, N5010/24/42 (P R O). Moreover after Germany had conquered the French iron ore mines, the Swedish exports of iron ore were considered to be of purely academic interest. Memorandum Sargent 17/6-40, N4974/124/42 (P R O).

${ }^{37}$ ) Ergebnisse der Besprechungen des deutschen und des schwedischen Regierungsausschusses in der Zeit von 26 Mai bis 6 Juni 1940, HP64Ct (UD A).

${ }^{38)}$ Handlingar rörande Sveriges utrikespolitik under andra världskriget, 1, Transiteringsfrågor, pp. $83 \mathrm{ff}$. Walter, Schnurre and Wied to Auswärtiges Amt 27/4-40, Handakten Clodius (A A), Aufzeichnung Schnurre 28/4-40, Aufzeichnung Wiehl 11/5-40, Handakten Wiehl, Schweden Bd 5 (A A).
} 
stocks of iron ore were at their lowest and whose demand for it was at its highest during that very summer. ${ }^{39}$ ) The German demands were also formalised in a paragraph in a confidential protocol which was appended to the trade agreement for the year 1941 and which was made in December $1940 .^{40}$ ) In January 1941 only a fraction of the Swedish miners were called up. ${ }^{41}$ )

Apart from exempting miners from conscription the Swedish authorities had to take all sorts of necessary steps of a 'technical' nature in order to allow the exports of iron ore to take place with the least possible interruption. These involved for example the traffic by rail between Kiruna and Luleå, simplification in the sample-taking of the iron ores and above all a great effort to make the loading of iron ore in the port of Luleå as rapid as possible (three shifts, etc.), so that they reached a volume which had been inconceivable until then..42) During the month of July 1940 almost 1.1 million tons were loaded, a record which was broken only in 1969 , but by that time the port of Lulea had been substantially extended. In Germany Sweden's good intentions for a maximum increase in iron ore exports were also noted with satisfaction. ${ }^{43}$ )

From the summer of 1940 Sweden's economic life slid-far too

${ }^{39}$ ) UD to the Commander-in-Chief $10 / 6-40, \mathrm{H} 40 \mathrm{Ct}$, documents in slip-case XVII, H40Ct (UD A).

$\left.{ }^{40}\right)$ The regulation applied to the miners in the mines of central Sweden, who mined the ore with a low phosphorus content which was of such importance for the German armament industry (above, p. $91 \mathrm{ff}$ ) and it was brought into effect for the first time in the agreement in the summer of 1940. Ergebnisse der Besprechungen des deutschen und des schwedischen Regierungsausschusses in der Zeit von 26 Mai bis 6 Juni 1940, and was repeated for the year 1941, UD to statssekreteraren i Socialdepartementet $30 / 12-40$, H40Ct (UD A).

${ }^{41}$ ) Out of Sweden's 5,266 miners who were eligible for military service, 2,165 were granted a postponement of it. Of the remainder the overwhelming majority were on leave of absence and only a very few were called up. Uppskovsförteckning (Postponement list) $21 / 1-41, \mathrm{H} 40 \mathrm{Ct}$ (UD A).

${ }^{42}$ ) Deutsches Konsulat, Luleå to Auswärtiges Amt 6/8-40, OKW, WiRüAmt, T77:699:1911420 (N A). A colourful description of the conditions in Lulea in the summer of 1940 is given in LKAB's newspaper Skip/Malmaren, October 1969.

${ }^{43}$ ) Wenzel to von Hanneken 15/5-40, OKW, WiRüAmt, T77:699:1911540 (N A), WiRüAmt, Vermerk über die Stockholmer Verhandlungen am 7. 8. und 9. Mai 1940, T77:699:1911542 (N A). 
smoothly from the point of view of the English ${ }^{44}$ )—more and more into the sphere of influence of the German economy. Exports were almost completely directed to Germany or to areas controlled by Germany. The price development in Swedish-German trade also became unprofitable from the point of view of Sweden. The German advantages in negotiation were exploited above all in the negotiations in the summer of 1940:

Table 39. Index of values in points for the Swedish-German trade in 1939-1941

$$
(1938=100)
$$

\begin{tabular}{lcccccc}
\hline & \multicolumn{2}{c}{ Exports f.o.b. } & & \multicolumn{2}{c}{ Imports c.i.f. } \\
\cline { 2 - 3 } \cline { 5 - 6 } \cline { 5 - 6 } \cline { 5 - 6 } Iron ore & Total & & Coal \& Coke & Total \\
\cline { 6 - 7 } 1939 & 91 & 93 & & 114 & 106 \\
1940 July & 91 & 105 & & 144 & 132 \\
August & 95 & 107 & & 168 & 147 \\
September & 96 & 106 & & 172 & 149 \\
October & 96 & 107 & & 190 & 159 \\
November & 93 & 107 & & 200 & 166 \\
December & 92 & 106 & & 200 & 167 \\
1941 First 6 months & 98 & 112 & & 213 & 182 \\
\hline
\end{tabular}

Source: PM rörande förändringarna i den svensk-tyska handeln under första halvåret 1941 (Memorandum on changes in the Swedish-German trade during the first six months of 1941), Statens Priskontrollnämnd 1/9-41. HP64Ct (UD A).

Germany was also granted credit by Sweden-but not in fact on the iron ore imports. As has been shown in an earlier chapter of this analysis, the iron ore was transported on board Swedish vessels to a much greater extent than had been decided on in the agreements. German vessels were built in Swedish shipyards. There was an extensive transit traffic to Norway and Finland on the Swedish railways. This traffic has been estimated at about $20 \%$ of Sweden's total goods traffic. Finally the so-called Gothenburg traffic, which supplied Sweden with

${ }^{44}$ ) An article by Hägglöf in the Berliner Börsenzeitung on German-Swedish trade relations supports the view of the English that Sweden had now decided on a quick and complete adaptation to the new conditions. Memorandum Addis 22/8-40, N6295/24/42 (P R O). 
certain vital goods imported from the west, could only take place with the consent of the Germans. ${ }^{45}$ )

The results produced in Sweden were not in fact entirely dictated by the thumb-screws used on her by Germany. Of course the large foreign trade with Germany was of extreme importance from an economic point of view. ${ }^{46}$ ) In this respect the Swedish government was therefore very keen on maintaining the exports of iron ore on as high a level as possible in order to keep the Swedish economy on its feet. ${ }^{47}$ )

At one time there was discussion in German diplomatic circles of the desire to use further thumb-screws on Sweden. It was thought that the maintenance of the status quo would produce the greatest advantages. Otherwise, the nearest thumb-screw to hand was to be found in a refusal to allow traffic via Gothenburg to continue. However this traffic also meant certain advantages for Germany. Part of the mineral oil which was imported via Gothenburg was in fact used in Swedish warships which convoyed German transports. ${ }^{48}$ )

\section{E. From the summer of 1943 onwards}

The great change in Swedish foreign policy took place during the summer and autumn of 1943. Certain hints of an imminent change in climate were already present in the autumn of 1942. In the trade agreement with Germany for the year 1943-signed in the middle of December 1942 - the Swedish negotiators were able, after promptings from the U.S.A., to advance their position, above all as regards credit

${ }^{45}$ ) See e.g. Die Gesandtschaft in Stockholm an das Auswärtige Amt 19/9-41, AzDAP, Ser. E, Bd I, pp. 434 f., Aufzeichnung des Gesandten Schnurre 1/12-41, ibid. pp. 754 ff., Dankwort to Auswärtiges Amt 29/7-42, Handakten Wiehl, Schweden Bd 6 (A A). As we know, German troops were also transported through Sweden in the summer of 1941 from Norway to Finland, the so-called Engelbrecht division. According to German opinion, the Swedish authorities had shown a very positive attitude towards the transit. Sweden should therefore be rewarded by a German consideration in the matter of the Gothenburg traffic. Richert to Günther 7/7-41, HP39HTy (UD A).

${ }^{46}$ ) Noted in passing in Boheman, pp. 20, 140.

${ }^{47}$ ) Trafikaktiebolaget Grängesberg-Oxelösund, styrelseprotokoll 21/12-42 (G A). Agreements recorded in the general cabinet meetings 28/6-43, HP64Ua (UD A).

${ }^{48}$ ) Die Gesandtschaft in Stockholm an das Auswärtige Amt 19/9-41, AzDAP, Ser. E, Bd I, pp. $434 \mathrm{f}$. 
facilities. ${ }^{49}$ ) However, the cold wind from the north did not pass unnoticed in Germany. An investigation had already started at the beginning of the year 1943 into the effects on German economic life of a possible cancellation of the Swedish iron ore deliveries. ${ }^{50}$ )

With the entry of the United States into the war and with Germany's military setbacks, the allies' demands on Sweden increased. The American negotiators in particular adopted a highly intransigent attitude towards Sweden's difficulties. In the beginning it was a question of studies of Swedish economic life and foreign trade, but soon there were demands for a reduction in the Swedish exports to Germany, which were also considered in the U.S.A. to be of vital importance for Germany's military power. ${ }^{51}$ )

However, the Swedes, for reasons which have already been mentioned, were not at all inclined to reduce their trade exchanges with Germany. The imports from Germany were of fundamental importance for the country's economy, and the allies would not be able to compensate for a possible reduction in them.

In the negotiations which took place between Sweden on the one hand and Great Britain and the U.S.A. on the other during the summer and autumn of 1943, of which Hägglöf has given a comprehensive description elsewhere, Sweden finally had to agree to a cancellation of the transit traffic and to a reduction in the exports to Germany for the year 1944. The maximum quantities for exports of iron ore were fixed at 7.5 million tons. The allied negotiators also made strong demands for reductions in the deliveries for 1943, but the Swedes managed to maintain successfully that they were bound by the agreement for that year. ${ }^{52}$ )

${ }^{49}$ ) PM 5/12-42, HP64Ct (UD A), Walter and Wied to Auswärtiges Amt 13/12-42, Sitzung des Handelspolitischen Ausschusses vom 21 Januar 1943, Handakten Wiehl, Schweden Bd. 6 (A A). The English also noted the German retreat in negotiations and connected it with the military successes of the allies. Memorandum Cocks 21/1242, N6487/56/42 (P R O).

$\left.{ }^{50}\right)$ Reichsvereinigung Eisen, Auswirkungen eines evtl. Ausfalles skandinavischer Erze, 26/2-43, R10III:76 (B A).

$\left.{ }^{51}\right)$ PM 22/2, 1/3-43, the legation in London to UD 14/5-43, PM 31/5-43, Hp64Ua (UD A), Medlicott, II, pp. $199 \mathrm{f}$.

${ }^{52}$ ) Hägglöf to UD 14/5-43, the legation in London to UD 14/6-43, Uppteckning av föredragning $\mathrm{i}$ allmän statsrådsberedning (Agreements recorded in general cabinet meetings) 28/6-43, HP64Ua (UD A), Medlicott, II, p. 466. 
However, during the year 1943 the exports of iron ore to Germany continued very smoothly (an exceptionally mild winter and no allied obstacles to the exports via Narvik) and the total quantity of exports to Germany came to 10.1 million tons for the whole year, in spite of the fact that the Swedish authorities felt obliged to resort to certain 'technical' measures to reduce the exports. In this context repair work on the railway between Kiruna and Luleå was suddenly begun, and the port of Luleå was closed two weeks earlier than was necessary from the point of view of the climate. In addition, personnel in the shore shipping ports in central Sweden were called up for military duty. When the high export figures-in spite of Swedish efforts-became known to the allies, their annoyance became even greater. ${ }^{53}$ )

When in the autumn of 1943 Sweden was to start negotiations with Germany about the exchange of goods during the year 1944, she was bound by the earlier agreement with the allies to reduce the exports to Germany of iron ore and ballbearings among other products. Furthermore, it was the first time in her war trade policy that the Swedish negotiators were bound by an agreement with the other party.

The reductions which Sweden suggested of course met with strong German protests and inter alia the German negotiators made threats about a blockade of Sweden and economic isolation. ${ }^{54}$ ) In actual fact the threat was an empty one. In August 1943 the German authorities had in fact carried out an analysis of Sweden's chances of resisting an economic blockade. The results of the analysis were discouraging for Germany. Sweden could tolerate an economic blockade for a year at least without any serious damage..$^{55}$ ) The fuel situation in particular, which had earlier been Sweden's great problem, now showed a clear improvement, thanks to a stringent economy and exceptionally mild winters. ${ }^{56}$ )

53) UD to the Swedish Minister in London 3/9-43, PM 20/9-43, H40Ct, Mitcheson to Ministry of Economic Warfare 7/9-43, N5388/42/42 (P R O), the legation in London to UD 4/11-43, Memorandum 1/12-43, H40Ct, Memorandum 20/1-44, the legation in London to Sohlman 21/3-44, HP64Ua (UD A).

${ }^{54)}$ PM 10/12-43, HP64Ct (UD A).

${ }^{55}$ ) Reichswirtschaftsministerium, Untersuchung über die Blockadefestigkeit der schwedischen Volkswirtschaft, T84:131:1432070 ff. (N A).

$\left.{ }^{56}\right)$ Reichsministerium für Rüstung und Kriegsproduktion, Deutsche Gesandtschaft, Wehrwirtschaftsbericht 15/2-44, T77:700:1913404 ff. (N A). 
The German negotiators laid heavy stress on the fact that a reduction in the Swedish exports of iron ore would mean an increase in the use of German domestic ores with a low iron content, which required larger quantities of coal, which in turn would mean that Sweden would hardly be able to receive the quantities for which she asked. ${ }^{57}$ ) After protracted negotiations Germany had to agree to the Swedish conditions. The quantity for the exports of iron ore was fixed at 7.1 million tons. ${ }^{58}$ )

The German negotiators had to acknowledge that a radical change had taken place in Swedish trade policy, and that the German thumbscrews no longer worked as they had done before. Instead other ways had to be tried. By making substantial deliveries of coal, coke and many other goods the German authorities hoped to stimulate exports from Sweden. ${ }^{59}$ ) The German deliveries to Sweden therefore became far greater in value in 1944 than their counterparts, and Germany's debt to Sweden disappeared over the years. However, there was no resulting increase in the imports of iron ore. Resignation spread throughout Germany. ${ }^{60}$ )

As a result of the increased pressure from the allies, especially from the American military officers, Sweden was compelled to adopt a more severe attitude towards Germany. Even the Soviet Union concurred in the demands for a reduction in the exports of iron ore. ${ }^{61}$ ) During

$\left.{ }^{57}\right)$ PM över sammanträde mellan de svenska och tyska regeringskommissionerna (Memorandum of meeting between the Swedish and German government commissions). 13/11-43, HP64Ct (UD A).

${ }^{58}$ ) The Germans' loss of prestige was considered so important that they tried to avoid publicity about the contents of the agreement. UD to the Swedish Minister in Washington $8 / 1-43$, press release $10 / 1-44$, HP64Ct (UD A). The Swedish press at least pointed out the reduction in exports of iron ore, e.g. Dagens Nyheter 11/1-44, Svenska Morgonbladet 12/1-44. However the Germans seemed satsified with the distribution according to grade, i.e. the relation between high phosphorus content and low phosphorus content. Reichsministerium für Rüstung und Kriegsproduktion, Deutsche Gesandtschaft, Wehrwirtschaftsbericht 15/1-44, T77:700:1913462 ff. (N A).

${ }^{59)}$ Funk to Speer 15/2-44, R7VI:383/1 (B A).

$\left.{ }^{60}\right)$ OKW, WiRüAmt, Betr. Vierteljahres-Besprechungen des deutschen und schwedischen Regierungsausschusses für Fragen des Zahlungs- und Warenverkehrs zwischen Deutschland und Schweden 8/5-44, T77:699:1910482 ff. (N A). Reichsministerium für Rüstung und Kriegsproduktion, Wehrwirtschaftsoffizier Schweden: Überblick für die Zeit 1/4-30/6-44, T77:699:1910338 ff. (N A).

61) Deutsche Gesandtschaft to Auswärtiges Amt 13/6-44, R7X:46 (B A). 
the spring of 1944 the Swedish authorities also took necessary measures of a technical nature to reduce the exports of iron ore. No ice-breaking aid was arranged for Lulea and the miners were called up in large numbers. ${ }^{62}$ ) Of course the Germans pointed out the artificial interruptions in the exports, but their words were backed up by no show of force. ${ }^{63}$ )

However, during the spring and summer of 1944 iron ore took second place to another strategic Swedish export product, viz. ballbearings. In the trade agreement for the year 1944 the exports of ballbearings had already been heavily cut down. In the spring of 1944 the allies' demands went further than the agreement with Sweden of the autumn of 1943. On one issue after the other Sweden had to give in: she heavily reduced her exports of ballbearings during the summer and stopped them completely from October onwards, and there was a gradual stoppage of exports of iron ore via the Baltic in August and September. Attempts by the Germans to get the iron ore shipped in larger quantities via the Swedish ports on the west coast failed due to a shortage of railway wagons in Sweden. American pressure on Sweden was strong, and in addition the allies interfered with the shipping in Narvik which did not increase. ${ }^{64}$ ) From the turn of the year 1944/45 all exports of iron ore to Germany ceased. Nor was any new agreement made with Germany.

What in fact were the thumb-screws of the allies, with which they extorted all these concessions from Sweden? The English maintained that during the years 1940-1942 Sweden had understandably deviated from a policy of neutrality, but that Germany's loss of strength now made it possible to return to a more strictly neutral line. ${ }^{65}$ ) The Americans were in fact far less subtle in argument. As before the imports controlled by the allies went via Gothenburg (liquid fuel and rubber) largely for

62) PM 6/4-44, HP 64Ua (UD A).

${ }^{63}$ ) PM över sammanträde mellan de svenska och tyska regeringskommissionerna (Memorandum of meeting between the Swedish and German government commissions) 25/4-44, HP64Ct (UD A), Aktennotiz über Besprechungen mit Ministerialrat Ludwig vom Reichswirtschaftsministerium 17/8-44, OKW, WiRüAmt T77:694:1904437 ff. (N A).

${ }^{64}$ ) The iron exports to Germany were of great symbolic significance for the Americans. Memorandum Foreign Office 10/11-44, N7064/3/42 (P R O).

${ }^{65}$ ) Uppteckning av föredragning $\mathrm{i}$ allmän statsrådsberedning (Agreements recorded in general cabinet meetings) 28/6-43 HP64Ua (UD A). 
the defence of Sweden. Of course these imports were given high priority, and threats of stopping the imports obviously constituted an effective means of pressure by the allies, ${ }^{66}$ ) especially as Germany's abilityand desire-to deliver these kinds of goods waned. ${ }^{67}$ ) On the other hand it was possible for example to hold out the prospect of increased deliveries of oil or aircraft in exchange for a reduction by Sweden of her exports of ballbearings to Germany. ${ }^{68}$ ) By degrees the tone grew sharper and Sweden was threatened with discrimination in trade policy after the war or with confiscation of Swedish property in the U.S.A. or in areas controlled by the allies, the blacklisting of Swedish shipyards which were building ships for Germany, et cetera. ${ }^{69}$ ) In order to increase the pressure on Sweden the allies also tried to involve the Soviet Union. ${ }^{70}$ )

The Swedish negotiators did not have much to show against these thumb-screws. They maintained that the adoption of measures against Germany which were too radical would provoke a German invasion of Sweden. Furthermore they pointed out that Sweden's neutrality was

${ }^{66}$ ) The English concession to oil transports to Sweden during the war was by no means automatic. It was contended that imports of oil by Sweden helped to increase the oil supply of the German sphere of influence and that the English would not gain very much from good trade relations with Sweden, after she had definitely come under German influence. Memorandum Addis 29/6-40, Memorandum Collier 29/7-40, $\mathrm{N} 5010 / 24 / 42$ (P R O). On the other hand it was maintained that a stoppage of the oil deliveries to Sweden would not bring about a reduction in the Swedish exports of iron ore to Germany. Ministry of Economic Warfare to Foreign Office 25/8-42, N4388/56/42 (P R O). On the differences between the U.S.A. and Great Britain in their assessments of tactics against Sweden, see e.g. Memorandum Foreign Office 16/7-44, N6375/3/42 (P R O). Medlicott, II, chapter XVI, passim.

${ }^{67}$ ) Ibid. The legation in London to UD 16/8-44, HP64Ua (UD A).

${ }^{68}$ ) Memorandum on the exports of ballbearings $15 / 3-44$, HP64Ct, PM $1 / 4-44$, PM 8/5-44, HP64Ua (UD A). Promises of oil deliveries had been used earlier to bring pressure to bear on Sweden over the transit question. Medlicott, II, pp. $191 \mathrm{f}$.

${ }^{69}$ ) Uppteckning av föredragning i allmän statsrådsberedning (Agreements recorded in general cabinet meetings) $28 / 6-43$, PM30/6-44, the legation in Washington to UD 15/8-44, HP64Ua (UD A), Johnson and Mallet to SKF 7/10-44 (copy), Memorandum after visiting Counsellor Ravndal at the U.S.A. legation 16/10-44, HP64Ct (UD A), Medlicott, II, p. 493. In 1944 an English Member of Parliament raised the question of blacklisting the Grängesbergsbolag. N4603/3/42 (P R O). The sensational but casually made threat of bombing Swedish industrial plants is not discussed here.

${ }^{70}$ ) Foreign Office to the Embassy in Moscow 5/8-44, N4778/3/42 (P R O). 
vital for humanitarian work at the end of the war and for active participation in international post-war work. ${ }^{71}$ )

Vis-à-vis the Germans, where the negotiating position had changed radically, the Swedish negotiators tried to produce objective justifications for the reduction in the exports. ${ }^{72}$ ) However, it was absolutely clear to the Germans that Sweden's behaviour was dictated by a change in the foreign political situation. ${ }^{73}$ ) Certainly it was hoped to some extent that Sweden's traditional needs for coal and coke would contribute to a softer Swedish line, but in actual fact Germany had already lost this source of strength. ${ }^{74}$ ) The winters of 1942/43 and 1943/44 had been unusually mild and the Swedish stocks of coal and coke were very substantial.

In the summer of 1944 the trade policy commission in Auswärtiges Amt considered the question of possible measures being taken against Sweden on account of her 'ausgesprochene Unfreundlichkeit'. After a lengthy discussion they were forced to acknowledge that countermeasures would hardly be in the German interest, since Germany's principle concern was not to interrupt the imports of iron ore. ${ }^{75}$ )

$\left.{ }^{71}\right)$ Uppteckning av föredragning i allmän statsrådsberedning (Agreements recorded in general cabinet meetings) 28/6-43, HP64Ua (UD A), Eden Memorandum 1/8-44, $\mathrm{N} 4777 / 3 / 42$ (P R O).

${ }^{72}$ ) On many occasions the arguments became bitter. When in the autumn of 1943 the Swedish negotiators sought to justify the reduction in the iron ore quantities for the year 1944, they gave as the reason the fact that in 1943 iron ore had accounted for too large a share of the total exports to Germany, and that it was desirable to have a better balance between the different kinds of goods. PM nr 2 över sammanträde mellan de svenska och tyska regeringskommissionerna (Memorandum no. 2 of the meeting between the Swedish and German government commissions) 9/11-43, HP64Ct (UD A), the legation in London to UD 9/8-44, HP64Ua (UD A). The reductions in the shipping of iron ore on board Swedish vessels in August 1944 were motivated by the factor of war risk insurance. OKM to Auswärtiges Amt 1/10-44, HaPol Schiffahrtsbeziehungen Deutschlands zu Schweden, Bd 5 (A A). The British Ambassador in Stockholm was able to report that the Swedish Cabinet Secretary 'was working very hard to arrange for stopping the iron ore traffic as soon as there was any real sign of naval activity in the Baltic'. Mallet to Foreign Office 28/7-44, $\mathrm{N} 6667 / 3 / 42$ (P R O).

${ }^{73}$ ) Stinnes to Köster 27/5-44 FD 3045/49 (IWM).

${ }^{74}$ ) Stinnes to Köster 17/4-44, FD 3045/49 (IWM).

${ }^{75}$ ) OKW, WiRüAmt, Sitzung des Handelspolitischen Ausschusses vom 29/7-44, T77:700:1911938 ff. (N A). 


\section{F. Concluding observations}

The foregoing account has stressed very strongly that the exports of iron ore to Germany constituted one of the main factors in Swedish war trade policy. It is also easily fitted into the larger pattern of foreign politics and economics.

Swedish trade policy, and hence the exports of iron ore, was expressed in yearly trade agreements, the contents of which were an excellent reflection of prevailing conditions of relative strength as between Sweden and the warring powers. It has also been established that Sweden had to play a fairly passive role in the shaping of the agreements, and that possible principles of neutrality had to be put aside.

Within the framework of the trade agreements Sweden did in fact have opportunities to act in a more active way. They concerned the 'technical' side, as has been apparent on several earlier occasions but of which Hägglöf and all the others make no mention. By respectively facilitating and obstructing the mining, transporting and re-loading of iron ore in Sweden and on board Swedish vessels, the Swedish authorities could modify the trade agreements. The modification always took place in accordance with the wishes of the superior power and therefore strengthened the tendency which prevailed at the time. 


\section{SUMMARY}

In contrast to earlier works - and they are many-which have discussed the Swedish exports of iron ore to Germany during the second world war, the present analysis has taken as its basis the conditions in the German steel industry. Several advantages seem to accrue from this. In starting with the German steel industry and its consumption of iron ore, the correct proportions of the imports of ore from Sweden are obtained at once, and it is their volume which has been over-emphasised in several earlier works. The study of the consumption of iron ore by the German steel industry has also meant that the iron ore imports from Sweden have been considered from the viewpoints of transport, business economics and technology, which have acquired a completely different magnitude than they had in earlier analyses, which have, almost without exception, neglected such problems or given a false impression of them.

By way of introduction (Chapter I) it was established that the German steel industry expanded greatly during the 1930s. It is true that during the actual war years production in 'Altreich' stagnated, but the military conquests in Europe-especially in France-brought about a continuing increase in total production, with 1943 as the peak year. In spite of the rise in production the steel industry suffered from too slow an increase in tempo. In fact in various areas the consumption of steel rose even more rapidly and not even urgent needs could be satisfied. Why then did the steel industry not increase its production? What were the bottlenecks? It could be established that during the end of the 1930s and during the second world war the steel industry suffered shortages of capacity, of scrap iron, of coke and of transport facilities which in various ways obstructed a satisfactory increase in production. Was even the iron ore supply a bottleneck?

The question leads on to an analysis of the German iron ore supply against the background of the events of foreign politics (Chapter II). 
The German level of self-support was low, and the supply was therefore a sensitive matter politically. In the literature the first year of the war, up to the conquest of France, has been considered a very difficult one from the point of view of the ore supply. The extensive stocks, the sharp increase in domestic mining and also the intensive imports from Sweden via the Baltic meant in fact that the production of steel did not stagnate because of a shortage of iron ore. With the military successes of the following years of the war Germany gained control over increased iron ore resources and, at the same time, indirect but satisfactory control over Swedish exports, and there was therefore no need for any shortage of iron ore on political grounds.

However, a political guarantee of the iron ore supply was not the only condition for its uninterrupted working. It was important for the supply of Swedish iron ore that sea transport functioned satisfactorily. It is clear from the analysis (Chapter III) that sea transport during the war was exposed to many great stresses. The stable pattern of loading and unloading ports from the middle period of the war was suddenly broken up. The great increase in the shortage of German vessels for the ore traffic was more serious, and this shortage was for various reasons accentuated more and more during the war. The fact that the iron ore deliveries from Sweden were nevertheless kept at a high level was due to the involvement of the Swedish merchant navy to an extent which went far beyond the framework of the agreement. The concession by Sweden was of course dictated by the political situation, but also the fact that large exports of iron ore were of great interest to Sweden too, since they made possible imports from Germany of goods which were vital to the economic life of Sweden.

With the good supply of iron ore through the political resources described above, questions of price were of course of importance in making the choice of a type of iron ore. When considering this question it is not enough to be content with a narrow comparison between the various iron ore prices: the perspective must be widened to include conditions generally in the steel industry, and then above all the factors of fuel, labour and capacity (Chapter IV). Swedish iron ore, because of its higher iron content, made less demands on fuel than the domestic ore with its low iron content or the minett ores. Because of this its demands for labour and capacity volume were smaller. While there was a substantial shortage of coke, labour and blast-furnace capacity in 
Germany during the war, Swedish iron ore became very much cheaper in a larger context-in spite of price rises due to the increased cost of sea freight - than the domestic ore with a low iron content or the minett ores. It is not possible to estimate the total 'profit' to the German war economy from the use of Swedish iron ore. Germany's efforts to maintain good relations with Sweden-inter alia by substantial exports of coal and coke, of which there was a shortage-suggest that the advantages for Germany were very great.

Apart from the profit to her national economy, Germany also gained other advantages through the substantial imports of Swedish iron ore. For the production of quality steel-for the armament industry inter alia-grades of ore with a low phosphorus content or scrap iron were required as raw materials (Chapter V). Iron ore with a low phosphorus content was not to be found within Germany's borders and the supply had to be imported instead. By virtue of the allies' superiority at sea a great proportion of the imports from Spain and North Africa was cut off. When there was no increase in the supply of scrap iron either, the imports of grades with a low phosphorus content became very important, even more as the Swedish deliveries of these grades were increasing.

Sweden's concessions to Germany in various fields were of course a manifestation of the situation in foreign politics. The Swedish exports of iron ore were an important link in the whole of Sweden's trade and foreign policy during the war (Chapter VI). The analysis shows that Sweden's exports of iron ore were determined by the higher political situation, and that the Swedish authorities played a fairly passive role. It was as impossible to maintain any kind of neutrality in this sector as it was in other spheres of Swedish foreign policy during the second world war. 


\begin{tabular}{ll} 
& \multicolumn{1}{c}{ ABBREVIATIONS } \\
A A & Archiv des Auswärtigen Amts, Bonn. \\
AzDAP & Akten zur Deutschen Auswärtigen Politik 1918-1945. \\
B A & Bundesarchiv, Koblenz. \\
FD & Foreign Document Centre, Imperial War Museum, London. \\
G A & Gränges' centralarkiv, Grängesberg. \\
IWM & Imperial War Museum, London. \\
PRO & Public Record Office, London. \\
R A & Riksarkivet, Stockholm. \\
SCB A & Statistiska Centralbyråns arkiv, Stockholm. \\
SOS & Sveriges Officiella Statistik. \\
UD A & Utrikesdepartementets arkiv, Stockholm.
\end{tabular}




\title{
REFERENCES
}

\author{
Manuscript sources \\ Riks a rkivet, Stockholm (R A) \\ (Swedish National Archives)
}

Bränslekommissionen, sekretariatets arkiv, ämnesordnade handlingar, ordförandens dossierer, vol. 401-402, 404-405.

Handelskommissionen, protokoll, Handlingar rörande utrikeshandeln, vol. 352.

U trikesdepartementets a rkiv, Stockholm (UD A)

(Foreign Office Archives)

Serierna HP39H Tyskland, H40Ct, H40Ba, HP64Ct, HP64Ba, HP64Ua.

St a t is ti s k a Centra 1 by råns a r kiv, Stockholm (SCB A)

(National Central Bureau of Statistics Archives)

Handelskommissionen, FIII:7.

Grän g e s' c en tra 1 a r ki v, Grängesberg (G A)

(Central Archives of Gränges Company)

Trafikaktiebolaget Grängesberg-Oxelösund, styrelseprotokoll.

Direktionens korrespondens.

Sammandrag av Narviks-, Luleå- och Oxelösundsleveranser.

$$
\text { Archiv des Auswärtigen A m ts, Bonn (A A) }
$$

HaPol Schweden, Eisenerz.

HaPol Schiffahrtsbeziehungen Deutschlands zu Schweden.

HaPol Schweden, Handel.

Handakten Wiehl.

Handakten von Behr.

B u n d e s a r c h i v, Koblenz (B A)

Reichsministerium für Bewaffnung und Munition/Rüstung und Kriegsproduktion, R3.

Reichswirtschaftsministerium, R7.

Reichsvereinigung Eisen, R10III.

Wirtschaftsgruppe Eisen schaffende Industrie, R13I.

Beauftragter für den Vierjahresplan, R26. 
$\mathrm{Nat}$ iona 1 Archives, Washington DC (N A)

Reichswirtschaftsministerium, T71.

Wehrwirtschafts- und Rüstungsamt, T77.

Private Austrian, Dutch and German Enterprises, T83.

Miscellaneous, T84.

Public Record Office, London(PRO)

War Cabinet Conclusions.

Foreign Office, General Correspondence.

I m peria 1 War M us e u m, London (IWM)

Foreign Document Centre (FD): Ministerium Speer, Handakten Milch.

\section{Printed sources}

Akten zur Deutschen Auswärtigen Politik 1918-1945 aus dem Archiv des Auswärtigen Amtes (AzDAP), Baden-Baden 1961-1972.

Estadistica del Commercio Exterior de España.

Handlingar rörande Sveriges politik under andra världskriget. Transiteringsfrågor (Aktstycken utgivna av Kungl. Utrikesdepartementet). Stockholm 1947.

Hitler, Adolf, 'Denkschrift Hitlers über die Aufgaben eines Vierjahresplans' (in: Vierteljahreshefte für Zeitgeschichte, III). 1955.

Hitlers Weisungen für die Kriegsführung 1939-1945, Dokumente des OKW. (Ed. Walther Hubatsch). Frankfurt am Main 1962.

Norges Offisielle Statistik: Norges Bergverksdrift. Norges Handel.

Riksdagstrycket.

Statistisches Handbuch von Deutschland 1928-1944. München 1949.

Statistisches Jahrbuch für das deutsche Reich 1938, 1941/42, Berlin 1938, 1942.

Sveriges Officiella Statistik (SOS), Handel, Bergshantering.

\section{Bibliography}

Boheman, Erik, På vakt. Kabinettssekreterare under andra världskriget. Stockholm 1954.

Bröyn, Per, Den svenske malmexport fram til okkupasjonen av Narvik i april 1940 med sarlig tanke på utförselen til Tyskland (Norge og den 2. verdenskrig: Mellom nöytrale og allierte). Oslo 1968.

Carroll, Berenice A., Design for a total War. Arms and Economics in the third Reich. The Hague 1968.

Gemeinfassliche Darstellung des Eisenhüttenwesens, 15 Aufl. Düsseldorf 1949.

Eichholtz, Dietrich, Geschichte der deutschen Kriegswirtschaft 1939-1945. Bd 1: 1939-1941. Berlin 1971.

Eneborg, Helmer, 'Om den svenska sjöfarten under inverkan av krigsförhållandena' (in: Svensk Export). 1940. 
—_, ‘Om krigets och krisens ekonomiska verkningar på den svenska sjöfarten' (in: Svensk Sjöfartstidning). 1942.

van der Esch, Patricia A. M., Prelude to War. The international repercussions on the Spanish civil war (1936-1939). The Hague 1951.

Fritz, Martin, Svensk järnmalmsexport 1883-1913 (Meddelanden från Ekonomiskhistoriska institutionen vid Göteborgs Universitet, 12). Göteborg 1967.

_- 'Swedish Iron Ore and German Steel 1939-1940' (in: The Scandinavian Economic History Review XXII:2). 1973.

Gemzell, Carl-Axel, Raeder, Hitler und Skandinavien. Der Kampf für einen maritimen Operationsplan. Lund 1965.

Hägglöf, Gunnar, Svensk krigshandelspolitik under andra världskriget. Stockholm 1958.

Janssen, Gregor, Das Ministerium Speer. Deutschlands Rüstung im Krieg. BerlinFrankfurt-Wien 1968.

Jäger, Jörg-Johannes, 'Sweden's Iron Ore Exports to Germany, 1933-1944' (in: The Scandinavian Economic History Review, XV). 1967.

—, Die wirtschaftliche Abhängigkeit des Dritten Reiches vom Ausland dargestellt am Beispiel der Stahlindustrie. Berlin 1969.

Karlbom, Rolf, 'Sweden's Iron Ore Exports to Germany 1933-1944' (in: The Scandinavian Economic History Review, XIII). 1965.

_- 'Swedish Iron Ore Exports to Germany 1933-1944, A reply' (in: The Scandinavian Economic History Review, XVI). 1968.

Klein, Burton H., Germany's Economic Preparations for War (Harvard Economic Studies, CIX). Cambridge, Mass. 1959.

Meinander, Nils, Gränges - en krönika om svensk järnmalm. Helsingfors 1968.

Medlicott, W. N., The Economic Blockade, I-II (History of the Second World War, United Kingdom Civil Series, Ed. by Sir Keith Hencock). London 1952-1959.

Merkes, Manfred, Die deutsche Politik gegenüber dem spanischen Bürgerkrieg 19361939. Bonn 1961.

Milward, Alan S., The German Economy at War. London 1965.

— ' 'Could Sweden have stopped the Second World War?' (in: The Scandinavian Economic History Review, XV). 1967.

- The New Order and the French Economy. Oxford 1970.

Müllern, Herman, 'Sveriges järnmalm och de krigförandes planer 1939-40. Synpunkter i efterkrigslitteraturen jämte några reflexioner' (in: Aktuellt och historiskt, 1). 1953.

Petzina, Dieter, Autarkiepolitik im Dritten Reich. Der nationalsozialistische Vierjahresplan. Stuttgart 1968.

Rheinländer, Paul, Die deutsche Eisen- und Stahlwirtschaft im Vierjahresplan (Schriften der Hochschule für Politik, I, 51). Berlin 1939.

Riedel, Mattias, 'Die Eisenerzversorgung der deutschen Hüttenindustrie zu Beginn des Zweiten Weltkrieges' (in: Vierteljahrschrift für Sozial- und Wirtschaftsgeschichte, Bd 58, Heft 4). 1971.

Deutschlands Rüstung im Zweiten Weltkrieg, Hitlers Konferenzen mit Albert Speer 1942-1945, Herausgegeben und eingeleitet von Willi A. Boelcke. Frankfurt am Main 1969. 
Sahlin, Ingemar-Öhman, Einar, Järn- och ståltillverkning (Tekniskt folkbibliotek). Stockholm 1940.

Sohlman, Rolf, Sveriges handelspolitik under andra världskriget (Orientering kring exportproblemen, Föreläsningsserie 1945, Handelshögskolan, Stockholm). Stockholm 1946.

Starck, Magnus, Allmän sjökrigshistoria 1930-1945, Del 1, 1930-1941. Stockholm 1971.

Steinweg, Günther, Die deutsche Handelsflotte im Zweiten Weltkrieg. Aufgaben und Schicksal. Göttingen 1954.

The United States Strategic Bombing Survey. The Effects of Strategic Bombing on the German War Economy. 1945.

Synnergren, Stig, Den politiska malmen. (Då - Nu - Sedan, Norrbotten väger tungt). Luleå 1972.

Thomas, Georg, Geschichte der deutschen Wehr- und Rüstungswirtschaft (19181943/45). (Schriften des Bundesarchivs, 14). Boppard am Rhein 1966.

Tägil, Sven, 'Recension av Gemzells avhandling' (in: Historisk Tidskrift, 1966:2). 1966.

Ulff, Tore, 'Krigets facit för de svenska tramprederierna' (in: Svensk Sjöfartstidning). 1944.

Wagenfür, Rolf, Die deutsche Industrie im Kriege 1939-1945, 2 Aufl. Berlin 1963.

Wahlbäck, Krister, Finlandsfrågan i svensk politik 1937-1940. Stockholm 1964.

Woodward, Sir Llewellyn, British Foreign Policy in the Second World War, I. London 1970.

Wretblad, P. E., (Söderlund, E.-Wretblad, P. E.), Fagerstabrukens historia III, nittonhundratalet. Uppsala 1957.

\author{
AFFÄRSVÄRLDEN \\ INDUSTRIA \\ IRON AND COAL TRADES REVIEW \\ SVENSK SJÖFARTSTIDNING
}




\section{List of tables}

1. The production of pig-iron in Germany $1928-1944 \ldots \ldots \ldots \ldots \ldots$. . . 9

2. The production of ingot steel in Germany $1928-1944 \ldots \ldots \ldots \ldots \ldots .10$

3. The quality of the German production of ingot steel in 1936-1944 . . . . 11

4. The production of pig-iron in Greater Germany $1939-1944$. . . . . . . . 14

5. The production of ingot steel in Greater Germany $1939-1944$. . . . . . . 14

6. German production of ingot steel 1939-1944 . . . . . . . . . . . . 15

7. Production of pig-iron and ingot steel in Greater Germany 1939-1944 . . . 16

8. The qualities of ingot steel produced in Greater Germany in 1943 . . . . 16

9. German steel consumption $1937-1940 \ldots \ldots \ldots \ldots \ldots$. . . . . . 17

10. The German scrap iron balance planned for $1943 \ldots \ldots \ldots \ldots \ldots .24$

11. The net German supply of scrap iron $1938-1943 \ldots \ldots \ldots \ldots \ldots .25$

12. Germany's production of crude ore $1928-1939 \ldots \ldots \ldots \ldots \ldots \ldots . . \ldots 32$

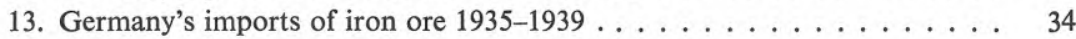

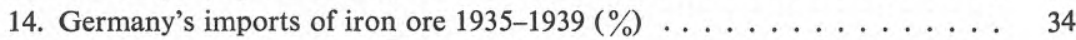

15. Germany's iron ore supply $1935-1939 \ldots \ldots \ldots \ldots \ldots \ldots \ldots$. . . . 40

16. Germany's iron ore supply $1935-1939(\%) \ldots \ldots \ldots \ldots \ldots$

17. Germany's iron ore production $1938-1940 \ldots \ldots \ldots \ldots \ldots \ldots \ldots .41$

18. Shipments from Narvik, September 1939-April 1940 . . . . . . . . . . 43

19. Shipments from Luleå in the autumn of $1939 \ldots \ldots \ldots$. . . . . . . 43

20. Germany's imports of iron ore $1938-1940 \ldots \ldots \ldots \ldots \ldots$. . . . 44

21. The iron ore production of Germany ('Altreich') $1940-1944 \ldots \ldots \ldots .48$

22. The production of iron ore within 'Reich' $1940-1944 \ldots \ldots$. . . . . . 49

23. Iron ore mined in 'Einflussgebiete' and used in 'Reich' 1941-1944 . . . . 50

24. 'Reich's' supply of 'domestic' iron ore $1940-1944 \ldots \ldots$. . . . . . . . 51

25. 'Reich's' imports of iron ore $1940-1944 \ldots \ldots \ldots \ldots$. . . . . . . . . . 51

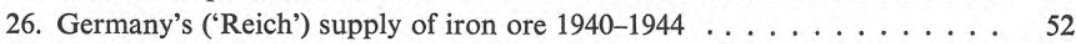

27. Germany's ('Reich') supply of iron ore 1940-1944 (\%) . . . . . . . . . 53

28. 'Altreich's' iron ore supply in 1937 and $1941-1942 \ldots \ldots \ldots \ldots \ldots . .53$

29. The German iron ore supply Oct. 1944-Jan. $1945 \ldots \ldots \ldots \ldots \ldots$

30. Stocks of iron ore in Germany in 1938-1944 . . . . . . . . . . 57

31. Sweden's iron ore exports to Germany via Narvik $1940-1944 \ldots$. . . . . 60

32. The Grängesbergsbolag's exports of iron ore as a percentage of Sweden's total iron ore exports $1935-1944 \ldots \ldots \ldots \ldots \ldots \ldots \ldots \ldots$. . . . 61

33. Iron ore shipping via Narvik, Luleå, Oxelösund and other Swedish ports

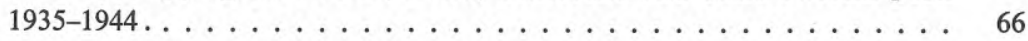


34. Percentage of the total imports of Swedish iron ore via the more significant import ports on the Continent 1935-1944 . . . . . . . . . . . 68

35. The composition of the iron ore shipping $1935-1944 \ldots \ldots \ldots$. . . . . . 71

36. The German merchant fleet 1939-1944. Size and changes . . . . . . . . 72

37. Germany's supply of iron ore with a low phosphorus content and net scrap iron in 1938 and $1941 \ldots \ldots \ldots$. . . . . . . . . . . . . 102

38. The Swedish exports in $1936-1944 \ldots \ldots \ldots \ldots$. . . . . . . . . 106

39. Index of values in points for the Swedish-German trade in 1939-1941 . . 118 


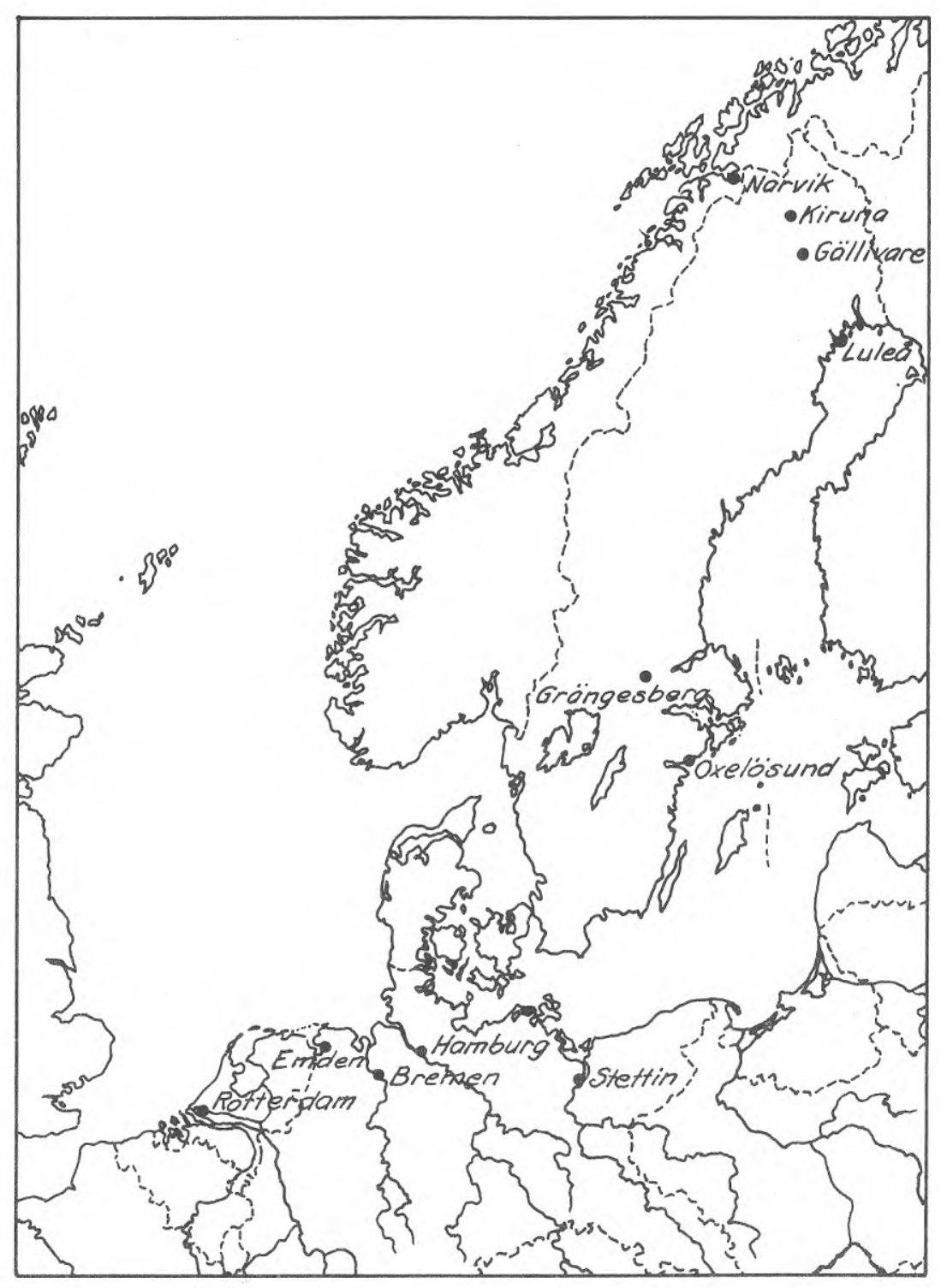

Important Swedish iron ore-fields, shipping ports and unloading ports on the Continent. 


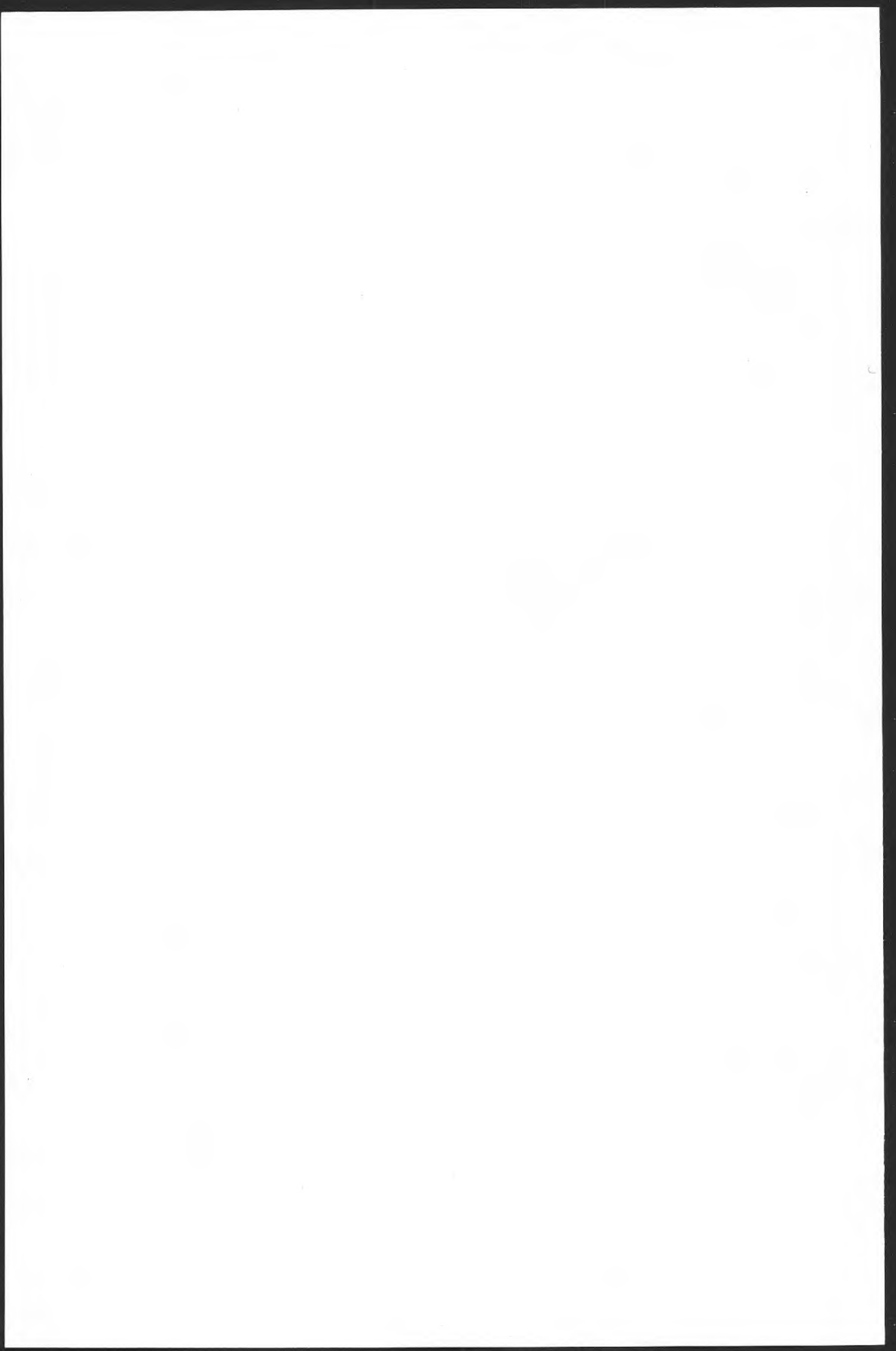




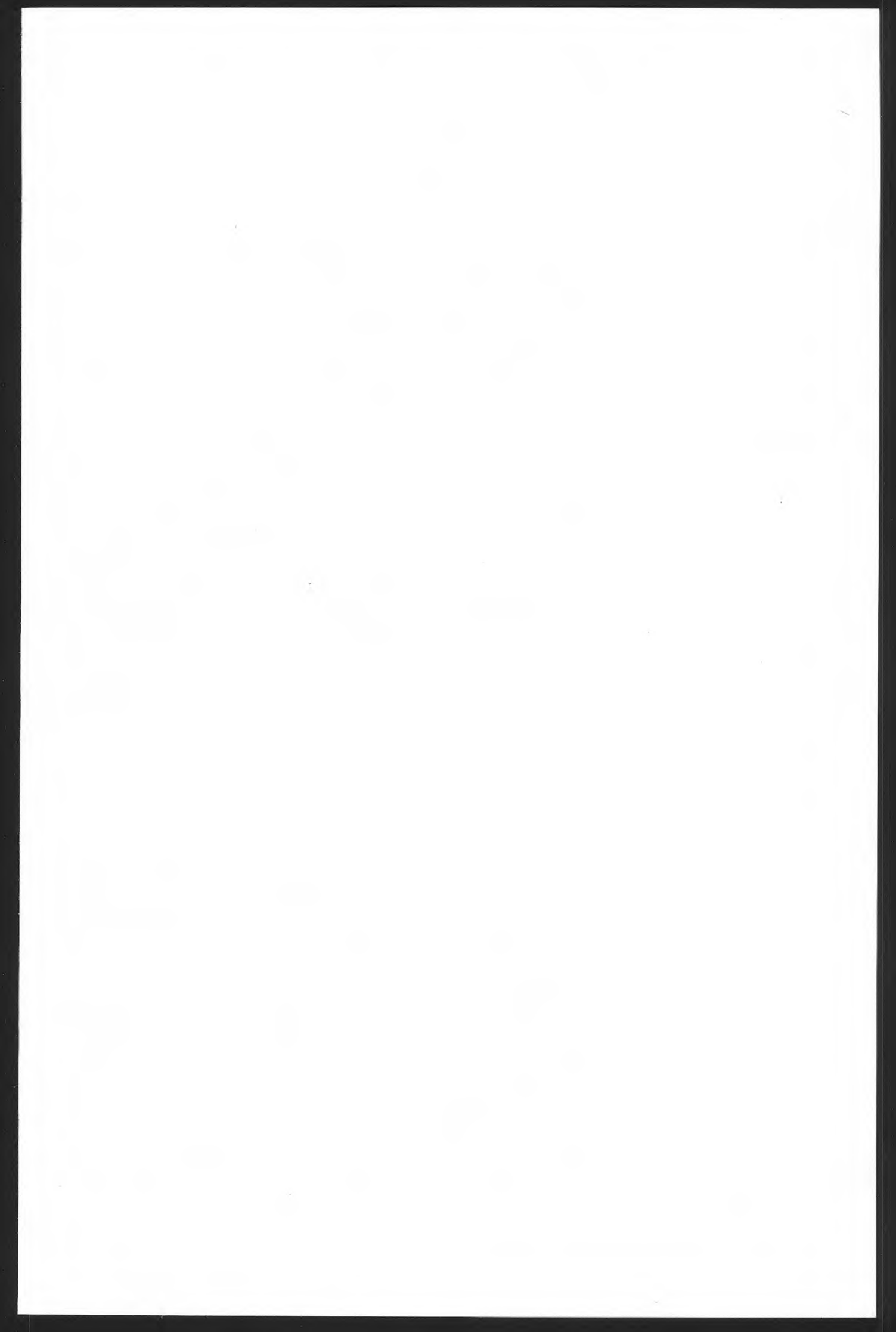




\section{Meddelanden från \\ Ekonomisk-historiska institutionen vid \\ Göteborgs universitet}

1. Sture Mårtenson: Agiot under kreditsedelepoken 1789-1802. 1958.

2. Marianne Nilsson: Öresundstullräkenskaperna som källa för fraktfarten genom Öresund under perioden 1690-1709. 1962.

3. Rolf Adamson: Den svenska järnhanteringens finansieringsförhållanden. Förlagsinteckningar 1800-1884. 1963.

4. Rolf Adamson: De svenska järnbrukens storleksutveckling och avsättningsinriktning 1796-1860. 1963.

5. Martin Fritz: Gustaf Emil Broms och Norrbottens järnmalm. En studie i finansieringsproblematiken under exploateringstiden 1891-1903. 1965.

6. Gertrud Wessberg: Vänersjöfarten under 1800-talets förra hälft. 1966.

7. Rolf Adamson: Järnavsättning och bruksfinansiering 1800-1860. 1966.

8. Sture Martinius: Befolkningsrörlighet under industrialismens inledningsskede i Sverige. 1967.

9. Ingemar Nygren: Svensk sparbanksutlåning 1820-1913. En analys av de större sparbankernas kreditgivning. 1967.

10. Carin Sällström-Nygren: Vattensågar och ångsågar i Norrland under 1800talet. 1967.

11. Martin Fritz: Järnmalmsproduktion och järnmalmsmarknad 1883-1913. De svenska exportföretagens produktionsutveckling, avsättningsinriktning och skeppningsförhållanden. 1967.

12. Martin Fritz: Svensk järnmalmsexport 1883-1913. 1967.

13. Gösta Lext: Mantalsskrivningen i Sverige före 1860. 1968.

14. Martin Fritz: Kirunagruvornas arbetskraft 1899-1905. Rekrytering och rörlighet. 1969.

15. Jan Kuuse: Varaktiga konsumtionsvarors spridning 1910-1965. En indikator på välståndsutvecklingen i Sverige. 1969. (Akademiförlaget).

16. Ingela Elison: Arbetarrörelse och samhälle i Göteborg 1910-1922. 1970.

17. Sture Martinius: Agrar kapitalbildning och finansiering 1833-1892. 1970.

18. Ingemar Nygren: Västsvenska sparbankers medelplacering 1820-1913. 1970.

19. Ulf Olsson: Lönepolitik och lönestruktur. Göteborgs verkstadsarbetare 19201949. 1970.

20. Jan Kuuse: Från redskap till maskiner. Mekaniseringsspridning och kommersialisering inom svenskt jordbruk 1860-1910. 1970. 


\section{Meddelanden från \\ Ekonomisk-historiska institutionen vid \\ Göteborgs universitet}

21. Sture Martinius: Jordbruk och ekonomisk tillväxt i Sverige 1830-1870. 1970.

22. Ingemar Nygren: Svenska sparbankers medelplacering 1914-1968. En undersökning av de större sparbankerna. 1970.

23. Jan Kuuse: Inkomstutveckling och förmögenhetsbildning. En undersökning av vissa yrkesgrupper 1924-1959. 1970.

24. Ulf Olsson: Regionala löneskillnader inom svensk verkstadsindustri 19131963. 1971.

25. Kent Olsson: Hushållsinkomst, inkomstfördelning och försörjningsbörda. En undersökning av vissa yrkesgrupper i Göteborg 1919-1960. 1972.

26. Artur Attman: The Russian and Polish Markets in international trade 15001650. 1973.

27. Artur Attman: Ryssland och Europa. En handelshistorisk översikt. 1973.

28. Ulf Olsson: Upprustning och verkstadsindustri i Sverige under det andra världskriget. 1973.

29. Martin Fritz: German Steel and Swedish Iron Ore 1939-1945. 1974.

ISBN 91-85196-03-7

Pris kr. 30:-

KUNGSBACKA 1974

ELANDERS BOKTRYCKERI AKTIEBOLAG 